\title{
Growth and Maintenance in the Plaice (Pleuronectes platessa L.). Part I. \\ By
}

Ben Dawes, A.R.C.S., D.I.C., Research Assistant at the Plymouth Laboratory.

With 19 Figures in the Text.

CONTENTS.

INTRODUCTION . . . . . . . . . . . 103

Methods . . . . . . . . . . . . . . . . 106

I. Results of Preliminary Experiments at Cawsand, 1928 . . . 108

1. Minimum Requirements and Maintenance . . . . . 108

2. Maximum Requirements and Growth . . . . . . 110

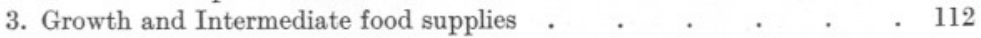

4. Conclusions drawn from the Experiments of $1928 \quad$. $\quad$. $\quad$. $\quad$. 113

II. Objections to the Form of the Preliminary Experiments $\quad . \quad$. 114

III. Modification of Apparatus and Methods (1929) $\quad . \quad$. $\quad . \quad$. 117

IV. Results of the Cawsand Experments of 1929 . . . . . . 118

1. Minimum Requirements and Maintenance $\quad$. $\quad$. . . . . 118

2. Maximum Requirements and Growth $\quad$. $\quad$. $\quad$. $\quad$. $\quad .121$

3. Conclusions drawn from the Experiments of 1929 (Cawsand) . . 130

V. Results of the Lympstone Experiments of 1929 . $\quad . \quad$. . 131

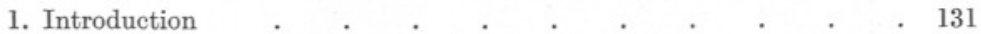

2. Minimum Requirements and Maintenance $\quad$. $\quad$. $\quad$. $\quad$. $\quad$.

3. Maximum Requirements and Growth . . . . . . 135

4. Conclusions drawn from the Experiments of 1929 (Lympstone) . $\quad$. 142

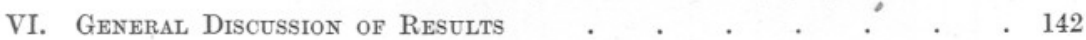

VII. TABLES $1-54$. . . . . . . . . . . 148-174

\section{INTRODUCTION.}

THE experiments to be described below were proposed by the Ministry of Agriculture and Fisheries and were carried out under the auspices of the Marine Biological Association, being subject to the direction of Dr. E. J. Allen, F.R.S., and Dr. E. S. Russell. Mr. Harvey, hydrographer to the Association, directed the construction of the sea-water pond and the fish boxes during the early stages of the preliminary work and assisted in organising supplies whenever alterations were made to the apparatus.

The aim of the experiments is to determine the food requirements of the plaice with respect to the maintenance of life apart from growth, and 
to ascertain what quantity of food is available for purposes of growth after basal requirements are satisfied, in the case of an actively feeding fish during its third season of growth. The work thus affords an

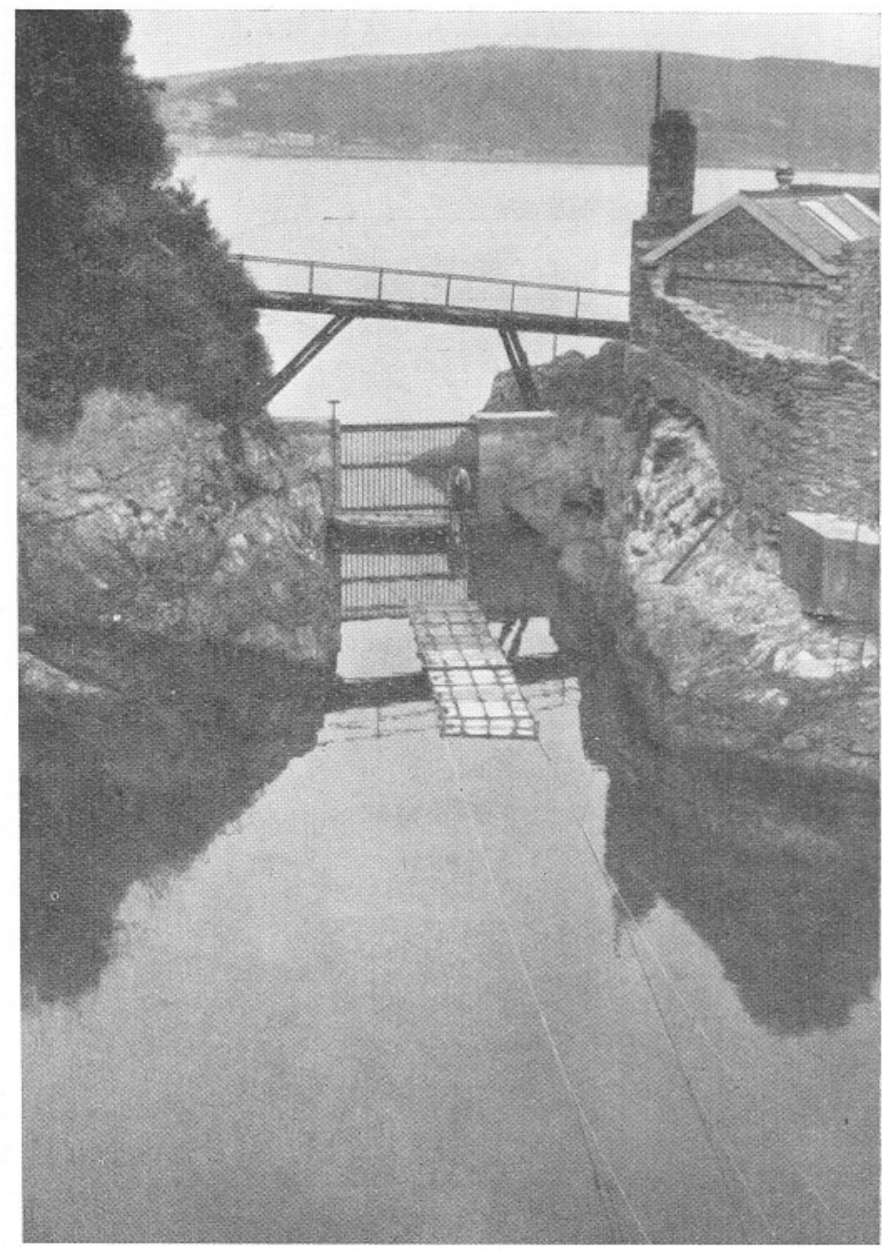

FIG. 1.-View looking out over the sea-water pond at Pier Cellars into Cawsand Bay, showing the constructed sea-wall with its grating. The hawser system is shown and the boxes are seen in situ in the neck of the pond. Only a portion of the pond is shown, but the low-water limits are, roughly, those seen in the picture.

indication of the growth-rate of a 2 -year old plaice and also the relation existing between the quantity of food taken and growth.

The investigations were carried out at Pier Cellars, which lies on the west shore of Cawsand Bay and thus immediately outside Plymouth 
Sound. Here, a rectangular cove some 120 feet by 70 feet opened on its northerly aspect, by a narrow neck roughly 20 feet wide, into 'Cawsand Bay. During the spring of 1928, when Mr. H. O. Bull was in charge of the work, this narrow neck was closed by a reinforced concrete sea-wall provided with a strong grating of vertical bars, horizontal girders, and stout $\frac{1}{2}$ mesh galvanised iron wire-netting. The grating measures 12 feet by 9 feet, and the total depth of the sea-wall is 15 feet, so that, as the grating is fitted into the upper part of the wall, with its long axis horizontal, a depth of 6 feet of water is accommodated in the cove at low water, to provide a permanent sea-water pond (Fig. 1). The pond possesses a shingle beach at its south end so that between mid-tide and low water

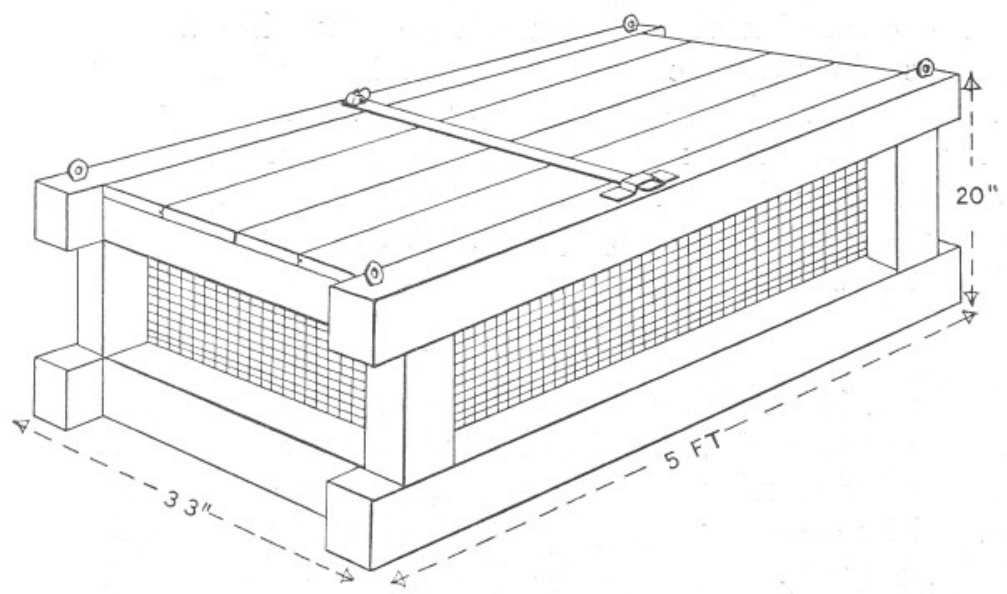

FIG. 2.-Diagram of a fish box as used in the Cawsand preliminary experiments of 1928 .

the depth of sea-water in it shallows from about 6 feet in the neck to nil on the beach. The depth of the portion of the wall below the grating was so arranged that the sea enters the pond about 3 hours before high tide and finally leaves it about 3 hours after high tide. Thus each day is divided into 4 parts of approximately six hours duration each. During the first period, say, the pond is in open communication with the sea outside, for the tide is either running into it or ebbing out of it. During the second period, the water in the pond is quiescent at its lower level, the tide being off the wall outside. The third and fourth periods each day are repetitions of the first and second periods of course. By this means, the pond is provided with an adequate circulation of water, for, with a spring tide rising to 16 feet above the Plymouth datum line, roughly 7 feet 6 inches of water flows over the wall through the grating, bringing the depth of water in the deepest part of the pond to about 13 feet 6 inches. 
Two steel wire hawsers were stretched out from end to end of the pond and over its surface, passing along the narrow neck. These were fixed at one end to the bars of the grating, at the other end to stout pins fixed vertically in the beach. The boxes into which the fish were placed subsequently, were slung on this hawser system, so that they floated at the surface of the water, as shown in Fig. 1.

Each box, with inside dimensions of $4 \mathrm{ft} .6 \mathrm{in} . \times 2 \mathrm{ft} .3 \mathrm{in} . \times 1 \mathrm{ft} .6 \mathrm{in}$., consisted of a strong deal framework and was provided with a solid bottom and a solid but halved, hinged lid, secured by means of hand bolts and a wrought-iron cross-bar fitted with a staple and a bolt and wing nut. The vertical faces of the box consisted during the early stages of the experiments of $\frac{1}{2}$-inch mesh galvanised iron wire-netting to ensure an adequate circulation of water through the box. Fig. 2 shows one of the boxes. Towards the end of the year 1928, when there appeared some likelihood of the boxes being damaged during gales, the framework of each box was further strengthened with wrought-iron plates and cross bolts, and an additional hawser system was introduced. But auxillary floats were employed in order to keep the boxes at the surface of the sea.

\section{METHODS.}

Upon completion of the preliminary arrangements, a number of 2-year old plaice were trawled in Cawsand Bay or in the nearby vicinity, kept under circulation on board s.s. Salpa and placed into storage boxes in the pond at Pier Cellars as promptly and carefully as possible. These fish were fed daily and were observed frequently for a number of days following their capture by Mr. H. O. Bull, who removed any individuals showing signs of ill-effect due to trawling or any other cause. From the remaining fish, 36 individuals were selected, this number being equally divided between the sexes. From the 18 fish of each sex three groups each containing 6 individuals were formed, each group being housed in a separate box. Thus 3 boxes each contained a group of 6 male fishes, and 3 boxes each a group of 6 females.

Subsequently, at the commencement of the preliminary experiments, one group of fish of each sex was provided with minimum rations, an attempt being made to satisfy basal requirements without allowing growth, i.e. to keep the length and weight of the fish constant. Trial and error methods together with periodic adjustments gave a reasonable measure of success. Further, one group of fish of each sex was supplied with maximum rations, arranged to satisfy the appetite of the fish and to allow full growth. The third groups of fish of each sex were given rations intermediate between the minimum and maximum ones.

The food supplied to the fish consisted of the best specimens of Mytilus 
edulis obtainable, opened, allowed to drain for 30 minutes, and then cut up into pieces of suitable size. Small particles of food were studiously avoided so as to prevent undue loss. In the description which follows,

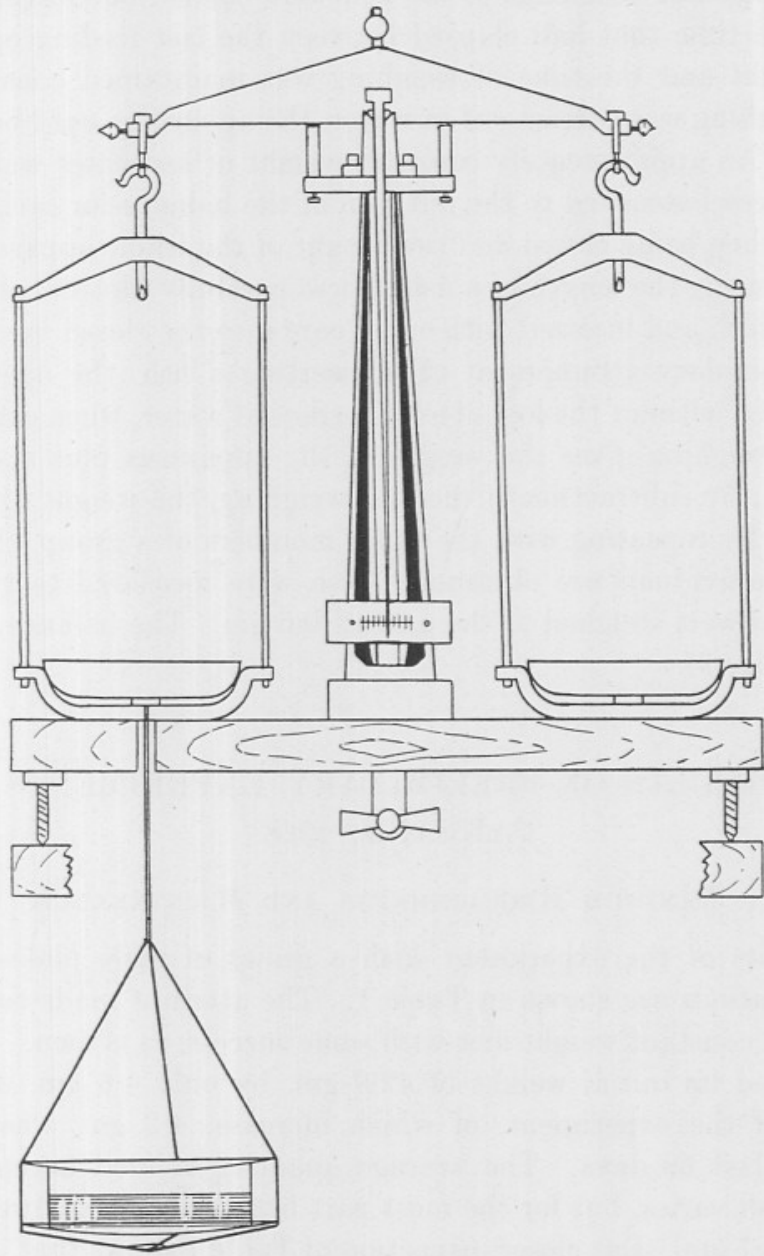

FIG. 3.-Diagram showing the weighing apparatus. The two large clock glasses and the shallow glass dish containing seawater are slung from the left side of the balance by means of a wire basket.

mention of food implies food of the nature mentioned above. Food rations were presented to each group of fish daily as consistently as possible and at a time when the water in the pond was in a quiescent state, so that the chances of food being washed away by a rising tide were minimal ones. The times of feeding were noted and daily records were 
kept of the temperature of the water in the vicinity of the boxes. A lookout was maintained for parts of rations uneaten and the behaviour of fish upon presentation of food was noted.

Measurings and weighings of the fish were carried out fortnightly, and always, the time that had elapsed between the last feeding operation of the fortnight and the time of weighing was maintained constant. The actual weighing was carried out in water, the apparatus used being shown in Fig. 3. An approximately constant weight of sea-water was placed in the glass vessel attached to the left arm of the balance for each weighing, the vessel then being closed and the weight of the whole apparatus taken. After measuring the length of a fish, it was carefully blotted with a clean, dry glass-cloth and inserted with equal care into the closed vessel. After a few preliminary attempts at thus inserting a fish, the operation can be performed without the loss of even a trace of water, when care is taken. A second weighing gives the weight of the apparatus plus a single fish, from which, by subtraction of the first weighing, the weight of the fish is obtained. By repeating with the other members of a group, the weights of all the individuals are obtained. Fish were measured to the nearest $0.1 \mathrm{~cm}$., and were weighed to the nearest $0.5 \mathrm{gm}$. The balance used is by Oertling (Fig. 3).

\section{RESULTS OF PRELIMINARY EXPERIMENTS AT CAWSAND, 1928.}

\section{Minimum Requirements and Maintenance.}

The results of the experiment with a group of male plaice fed with minimum rations are shown in Table 1 . The attempt made to maintain the fish at a constant weight met with some success, as is seen. The mean fish increased its initial weight of $42 \cdot 0 \mathrm{gm}$. by only $4.8 \mathrm{gm}$. during the 176 days of the experiment, of which increase, $4 \cdot 2 \mathrm{gm}$. was obtained during the last 39 days. The average quantity of food taken daily by the mean fish varies, but for the most part between such narrow limits as $0 \cdot 6 \mathrm{gm}$. to $0 \cdot 7 \mathrm{gm}$. But closer inspection of Table 1 shows that the results of the experiment are modified by a remarkable event. It is seen that the fish designated A1 steadily declined during the course of the experiment, and gradually lost weight until late November, when it died.

It was observed during feeding operations that these male fish generally displayed avidity for food, rising towards the surface of the water as soon as it was presented, and even snapping at each other at feeding time before food actually was offered to them. As soon as the lid of the box was opened, the fish were seen to be in great readiness to take food. But the fish $\mathrm{A} 1$, and during the early stages of the experiment $\mathrm{A} 5$ also, 
was invariably too slow to obtain food. After a short time it made no attempt to compete with its fellows, but steadily sulked in a corner of the box, watching the feeding attempts of the others. It was completely subjugated and, as the rations were taken by the other fish immediately they were placed in the water, it is doubtful if it succeeded at all in obtaining an appreciable quantity of food. Because of this factor, it seems reasonable to suggest that the fish $\mathrm{Al}$ be excluded from consideration in the preparation of weight-length averages and mean maintenance ration estimates. It must be observed here that although individual values are arranged in order in Table 1 , yet it was not possible to recognise each individual with certainty during the course of the experiment, and the order presented is not the only possible one. But certain fish are definitely recognisable, e.g. A1, which was originally the longest fish in the group and which came to be distinguished by its slight weight, and A5, the smallest fish of the group.

The values shown on the right-hand side of Table 1 are obtained when the fish A1 is excluded from consideration. There appears to be reason for maintaining that they are more accurate than values which take this fish into consideration. During the course of the experiment, the mean fish increased its initial weight of $41 \cdot 6 \mathrm{gm}$. by $5 \cdot 2 \mathrm{gm}$., while the daily food allowance varied, for a greater part of the time between $0.7 \mathrm{gm}$. and $0.8 \mathrm{gm}$. Thus, if the suggestion made above is accepted, the value for the daily maintenance ration obtained from data concerning the whole group must be increased by $0.1 \mathrm{gm}$. Between August 14th and November 30th the corrected daily ration varies between $0 \cdot 017$ and 0.019 of the average body-weight for each period, and may be taken as approximately constant at 0.018 for a $42.0 \mathrm{gm}$. mean fish. During December and the early part of January the fraction of the average body-weight which must be supplied in food per day, which fraction will subsequently be referred to as the maintenance ratio, falls appreciably. As is shown in Table 1, during the last 39 days of the experiment, the corrected mean fish increased its weight by $4 \cdot 2 \mathrm{gm}$. as against $1.0 \mathrm{gm}$. for the previous 137 days on a reduced ration per day corresponding to $0 \cdot 014-0 \cdot 015$ of the average bodyweight.

The results of the experiment with a group of female fish fed with minimum rations are presented in Table 2. The problem of the decline of certain individuals, due to lack of success in the competition for food within the minimum groups, is obvious, if not as well marked as in the cases of the males. But the declining females B1 and B5 undoubtedly were able to obtain food, since for periods up to 32 days their body-weights were maintained constant. These fish showed the same disregard for food as did Al amongst the males, but it is impossible to correct the mean values obtained for the whole group, since for periods they undoubtedly 
must have obtained food. In great probability, the mean values shown are higher as regards food quantities than the true values desired.

The females were supplied with rations similar to those given to the males, and because of the difference in size were thus allowed more than sufficient for purposes of maintenance. Thus, during 147 days from August 14th, a daily allowance of rather more than $0 \cdot 6 \mathrm{gm}$. on the average resulted in an increase in body-weight of the mean fish of $15 \cdot 7 \mathrm{gm}$. It is seen from Table 2 that during the period ending July 30th, a daily allowance of $0.5 \mathrm{gm}$. of food resulted in an increase in body-weight of $0.9 \mathrm{gm}$., while in the following period $0.4 \mathrm{gm}$. of food per day enabled the bodyweight to be kept approximately constant. It appears likely that for female plaice of $25 \cdot 0 \mathrm{gm}$. body-weight, a daily food allowance of $0 \cdot 4$ $0.5 \mathrm{gm}$. would prove adequate. The maintenance ratio would lie between 0.016 and 0.020 , and would compare fairly closely with that obtained for males.

\section{Maximum Requirements and Growth.}

Data concerning fully growing male fish are presented in Table 3. After 176 days of growth the mean fish had increased its initial size of $16.0 \mathrm{~cm}$. and $38.8 \mathrm{gm}$. by $6.6 \mathrm{~cm}$. and $86.0 \mathrm{gm}$. The initial length is thus increased by rather less than half its value while the initial weight is rather more than tripled. The total quantity of food taken is about $1129 \mathrm{gm}$., or approximately 14 times the average body-weight for the whole period, and an average of about $6 \cdot 4 \mathrm{gm}$. per day. Of the whole quantity of food consumed, an uncertain quantity had been used for purposes of maintenance. It is not possible to know the exact amount of food necessary to maintain this mean fish, since the values determined experimentally for the single set of males kept on minimum rations do not correspond to those of fully growing fish, as the maintenance requirements must vary with size. But an approximation will be obtained if it is assumed, in the absence of experimental data in these preliminary experiments, that the ratio, spoken of as the maintenance ratio (M), is constant for fish of any size within the range of these experiments. In Table 3 are given estimations of the maintenance requirements of the mean, fully growing male fish, the maintenance ratio being taken from the corresponding periods shown in Table 1. These estimates are probably high, expecially during the latter stages of the experiment, because it is likely that the value of the ratio will fall with increase in size of a fish. But this rough estimate indicates that approximately $\frac{1}{5}$ th part of the total food consumed is used up in satisfying the maintenance requirements of the mean fish, only $\frac{4}{5}$ ths of the total being available for purposes of growth. About $900 \mathrm{gm}$. of food used for growth purposes produced $86 \mathrm{gm}$. of mean fish, so that for 
the whole period the fish requires 10 to $11 \mathrm{gm}$. of food over and above the maintenance ration to increase its weight by $1 \cdot 0 \mathrm{gm}$.

It is seen from Table 3 that the increments of growth in weight are much more irregular than the corresponding food increments. Thus, for the three periods included between August 14th and September 26th, the average quantity of food consumed per day falls slightly in successive periods, while the increase in weight falls for the second period to rise again in the third. There is also a striking acceleration of growth in weight during early December-which appears disproportionate to the quantity of food taken. This may be due in part to a fall in the quantity of food necessary for pure maintenance allowing of more food being available for purposes of growth. But it is probably also dependent upon other factors, as a glance at the results for the period ending January 8th will serve to show.

The results of the experiment with fully growing female fish are more complete than those concerning corresponding males. There was no accident such as interfered with the results in the latter case, when a box was forced open and three fishes gained their freedom. From Table 4, it is seen that the mean female fish was initially $16.1 \mathrm{~cm}$. in length and $43.3 \mathrm{gm}$. in weight, and was finally $23.3 \mathrm{~cm}$. long and weighed $151 \cdot 2 \mathrm{gm}$., showing an increase in length of $7 \cdot 2 \mathrm{~cm}$, in weight of $107.9 \mathrm{gm}$. Considerable variation in growth occurs, for while the initial weight of D4 is less than tripled, that of D5 is quadrupled. It is interesting to note that during a whole growth-season a small initial difference in weight between two fishes may become considerably amplified. Thus in an environment holding an abundance of food, an initial difference of $13 \mathrm{gm}$. in the body-weights of the fishes D5 and D6 (Table 4) results in a difference of $90 \mathrm{gm}$. in these weights at the end of the growth-season. The same fact is shown by comparison of the initial and final body-weights of D2 with those of D5.

During the entire period, the mean fish takes $1129 \mathrm{gm}$. of food-rather less than 12 times the average body-weight for the period, and an average of $6.4 \mathrm{gm}$. per day. It appears likely that the females make better use of food for purposes of growth than do the males, since $1129 \mathrm{gm}$. of food produce $107.9 \mathrm{gm}$. of mean female fish as against $86.0 \mathrm{gm}$. of mean male fish, when the initial sizes were comparable.

No attempt has been made to estimate the maintenance requirements of the fully growing female fish. It was noted above that considerable growth took place in the mean female fish supplied with maintenance rations. Moreover, the selection of fish at the commencement of the preliminary experiments was such that, despite considerable growth, the females given minimum rations were smaller at the end of the experiment than were the females given maximum rations at the commencement. 
But, assuming that the maintenance ratio is approximately constant at from $0 \cdot 018$ to $0 \cdot 020$, the maintenance requirements of the fully growing female fish will range from $200 \mathrm{gm}$. to $245 \mathrm{gm}$. of food for the whole period. This rough estimate is suggested tentatively.

\section{Growth and Intermediate Food Supplies.}

As was mentioned above, groups of male and female fish, each containing six individuals, were supplied with quantities of food intermediate in value between the minimum and maximum rations. This intermediate ration was about $\frac{1}{3} \mathrm{rd}$ of the maximum one. The results of the experiment with males are shown in Table 5, where it is seen that the mean fish increased its initial size of $16.0 \mathrm{~cm}$. and $42.5 \mathrm{gm}$. by $3.8 \mathrm{~cm}$. and $51.1 \mathrm{gm}$. during the 176 days of the experiment. During this period it took $393 \mathrm{gm}$. of food, an average of $2 \cdot 2 \mathrm{gm}$. per day. Table 7 shows initial lengths and weights, final lengths and weights and the total quantities of food consumed by each of the three groups of each sex. It is seen that in maximum-fed males, $13.3 \mathrm{gm}$. of food are required to produce $1.0 \mathrm{gm}$. of fish on an average for the whole period of 176 days. In the case of intermediate-fed males, only $7 \cdot 7 \mathrm{gm}$. of food is required to produce the same quantity of mean fish. Thus there appears to be some difference in efficiency of the two groups. This question will be returned to later.

Returning to Table 5, it will be seen that the initially larger fish fared much better than did the smaller ones, c.p. E1, E3, and E4 with E2 and E6. Ultimately, the group comes to consist of a mixture of " maximum " and "minimum" fish. A problem comparable with that of the decline of individuals in the minimum groups thus arises, due to the competition for food existing between the members of the group. It was observed during feeding operations that certain individuals took liberal helpings of food while others made no attempts to obtain it while under observation. It was made a rule after a short time to close up the box immediately following the presentation of food in order to eliminate the possibility of fish refusing to take food in the presence of the observer. But in spite of such a precaution, certain individuals soon come to dominate the group, others apparently being subjugated. Undoubtedly, such fish as come to dominate a group will take maximum rations as far as possible, while subjugated fish may or may not succeed in obtaining food.

The feature mentioned immediately above is also shown amongst females of the intermediate groups. In Table 6 it is shown that the initially smallest fish, F6, does not succeed in doubling its initial weight during the course of the experiment, while other fish easily achieve this result (F1, F2, F3 and F4). But the results of the competition for food 
within the intermediate-fed groups are not as well marked among females as among males.

A comparison of Tables 5 and 6 will serve to show that the growth of intermediate-fed females closely follows that of the corresponding males. Table 7 shows that these females make rather more use of focd for purposes of growth than did the corresponding males, $7 \cdot 2 \mathrm{gm}$, and $7 \cdot 7 \mathrm{gm}$. of food being required to produce $1.0 \mathrm{gm}$. of fish on the average, for females and males respectively. The difference is not as well marked, however, as in the cases of maximum-fed fish, where the corresponding focd quantities are $10.5 \mathrm{gm}$. and $13.3 \mathrm{gm}$. But in both male and female groups there appears to be a marked increase in efficiency in the intermediate groups. This is difficult to explain, particularly in the case of the males, where a virtual mixture of maximum and minimum fish obtains. In order merely to balance the food bill of the intermediate group for the whole pericd, such a mixture of fish would need to consist of not more than two maximum fish to four minimum ones. Yet three or four of the fishes in the intermediate male group could be regarded as maximum fish as far as size is concerned, if rather poor ones. There thus appears some reason to believe that fish make more use of food for purposes of growth when it is present in medium quantity, than when it is particularly abundant. In work on digestion in the plaice, the results of which are unpublished as yet, it was found that food stays longer in the stomach if no second meal is given than it does if a second meal is taken. There may be relatively more complete absorption of food substances, therefore, when food is relatively more scarce. But it is not intended to stress unduly these differences of efficiency. It appears possible that although food from a previous meal was never observed in a box containing maximum-fed fish, yet particles of food left over from a meal might conceivably have been swept out of the box by a rising tide. Thus the question is left open to doubt on the results of the 1928 experiments alone. But it appears that much interesting information would be obtained by following up such suggestions as are here afforded by more conclusive experiments.

\section{Conclusions Drawn from the Experiments of 1928.}

(1) A male fish $16.0 \mathrm{~cm}$. in length and $42 \mathrm{gm}$. in weight requires approximately $0 \cdot 7-0.8 \mathrm{gm}$. of focd per day in order to maintain its weight constant. For the major part of a growth-season of 176 days the maintenance ratio, i.e. the ratio of the quantity of food required daily to the body-weight, varied from $0 \cdot 017$ to $0 \cdot 019$, and may be taken as approximately constant at $0 \cdot 018$. During the months of December and January the ratio falls to $0 \cdot 014$. 
(2) A female fish initially $13.4 \mathrm{~cm}$. in length and $24.3 \mathrm{gm}$. in weight is able to increase its weight by $16 \cdot 7 \mathrm{gm}$. when supplied with an average daily food ration of $0 \cdot 6 \mathrm{gm}$. for 176 days. It is suggested that the true maintenance ration for such a fish lies between $0.4 \mathrm{gm}$. and $0.5 \mathrm{gm}$. per day. The maintenance ratio would then lie between $0 \cdot 016$ and $0 \cdot 020$.

(3) A fully feeding " mean " male fish initially $16.0 \mathrm{~cm}$. in length and $38.8 \mathrm{gm}$. in weight increased its length by about $6.6 \mathrm{~cm}$. and its weight by about $86 \mathrm{gm}$. during a period of 176 days from July $16 \mathrm{th}$, 1928. It consumed $1129 \mathrm{gm}$. of food, an average of about $6 \cdot 4 \mathrm{gm}$. per day for the period. It is estimated that roughly $\frac{7}{5}$ th of the total quantity of food consumed was required for purposes of maintenance.

(4) A fully feeding " mean" female fish, initially $16 \cdot 1 \mathrm{~cm}$. in length and $43 \cdot 3 \mathrm{gm}$. in weight, increased its length by $7 \cdot 2 \mathrm{~cm}$. and its weight by $107 \cdot 9 \mathrm{gm}$. during a period of 176 days following July $16 \mathrm{th}, 1928$. It appears probable that, since the total food taken was the same in quantity as that taken by the corresponding male fish, females make slightly better use of food for purposes of growth than do males.

(5) Considerable variation is shown in the growth taking place in different individuals in an environment holding an abundance of food. A difference of weight of 12-13 gm. between two fish at the commencement of the third season of growth may become amplified into a difference of $80-90 \mathrm{gm}$. by the end of this season.

(6) Fish supplied with daily rations of food intermediate in value between maximum and maintenance rations and about $\frac{1}{3}$ rd the value of the former, appear to make better use of food for purposes of growth than do fish supplied with maximum rations. A comparison of efficiencies is given in Table 7 and probable explanations are afforded.

(7) In fully feeding fish, there appears to be no simple relation between the quantity of food consumed in a given period and the increase in weight.

\section{OBJECTIONS TO THE FORM OF THE PRELIMINARY EXPERIMENTS.}

Among the objections raised to the form of the preliminary experiments, there are several which are capable of being remedied or removed altogether. It was seen that, if a group of fish is supplied with food sufficient merely to satisfy maintenance requirements, the ration is not 


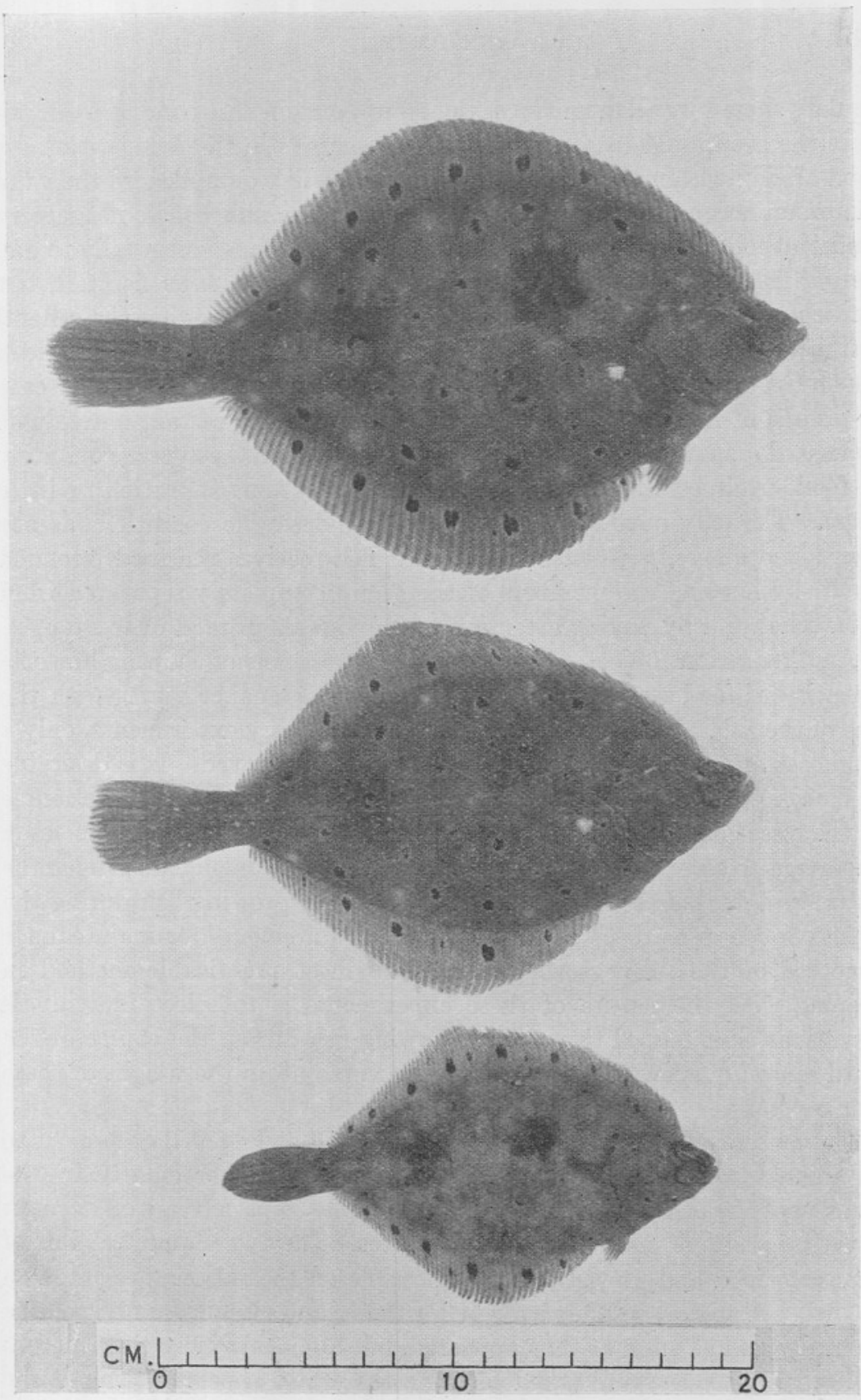

FIG. 4.-Female plaice photographed at the end of the preliminary experiments of 1928 [Cawsand]. The lengths are $16.8 \mathrm{~cm}$. [bottom], $22.6 \mathrm{~cm}$. [middle], and $25 \cdot 7 \mathrm{~cm}$. [top]. At the commencement of the experiments, the fish were of approximately equal size. The fish shown at the top of the figure was supplied with maximum rations and growth was unrestrieted; that shown at the bottom was supplied with minimum rations sufficient to satisfy maintenance requirements without allowing of growth, while the middle fish consumed rations intermediate in quantity between the maximum and minimum ones, so that growth was slightly restricted. 
equally shared by all members of the group, certain fish coming to dominate the group and to overpower other members in the competition for food arising within the group. The dominant fish obtain more than the minimum ration intended for them, while the remaining fish do not receive sufficient food for purposes of maintenance, and decline, eventually to die. Larger fish may succeed in this competition where smaller fish fail, but size is not the sole factor determining success. It may be that the general condition of the fish is a factor. In any case it is not possible to ascertain which fish of such a group would fail to obtain food. Similarly in the case of groups of fish supplied with intermediate rations, certain individuals come to dominate the situation and obtain more than the average quantity of food, while certain others obtain a bare maintenance ration or little more. The only means of removing such undesirable conditions as are mentioned above, is to ensure that each fish receives the food intended for it, by keeping the members of the group completely separated from each other and by paying attention to individuals instead of to groups.

Another serious objection is the lack of any means of showing how the quantity of food necessary for purposes of maintenance varies with the size of the fish. During the course of the preliminary experiments, only a single set of minimum-fed fish of each sex was employed. It is desirable to show how the maintenance requirements of a fish vary during the course of the year, e.g. with differences of water temperature, but it is more important to ascertain how they vary for fish of sizes included between the initial and final sizes of the maximum-fed, fully growing fish during the same period, so as to be able to infer the requirements for maintenance purposes of the fully growing fish. The most practicable method in keeping with the nature of these experiments is to select individuals of various sizes passed through by growing fish during the course of the . third season of growth and to endeavour to maintain the weight of these fish constant.

The presence of prawns in the sea-water pond at Pier Cellars proved to be a great source of annoyance. They were found regularly in the vicinity of the boxes, into which they were able to pass freely on account of the large size of mesh of the vertical faces. They were quite capable of removing food and preyed as far as possible on the rations presented to the fish. A special watch was kept for them, and they were removed as promptly and as often as they appeared, but obviously more than merely palliative measures were called for. As there also appeared some doubt as to whether or not food was ever swept out of the boxes, it seemed advisable to substitute a finer meshwork into the vertical faces of the boxes, a meshwork large enough to allow of an adequate circulation of water through the boxes and at the same time small enough to prevent the ingress of prawns and the egress of food particles. 


\section{MODIFICATION OF APPARATUS AND METHODS (1929).}

Before commencing the experiments of 1929 , alterations were made to the apparatus in order to eliminate the undesirable factors mentioned above. The $\frac{1}{2}$-in. mesh wire-netting windows of the boxes were removed and, in place of these, windows of perforated ebonite were substituted. Every box was provided with 4 windows each 12 in. $\times 12$ in., and 4 more each 12 in. $\times 6$ in., the perforations being $\frac{3}{16}$ in. in diameter and being set $\frac{5}{16}$ in. apart. The cavity of each box was divided into 4 equal compartments, by means of $\frac{1}{2}$-in. mesh, wire-netting partitions, provided with a 6 -in. sill at the base to prevent the passage of food from one compartment of a box into another. Six boxes were thus transformed, so that accommodation was afforded for 24 fishes, and it was decided to continue the experiment with maximum-fed and minimum-fed fish only.*

During the course of the revised experiments, each fish was kept quite separated from its fellows, and received an independent food ration daily, or as nearly daily as was found practicable. In all cases, whether of minimum-fed or maximum-fed fish, food was placed in the box one day and the portion uneaten was weighed back before food was presented on the following day. It is important to observe carefully what portion of food is left over, particularly as a measure of the appetite of a fish on one day is by no means a certain measure for the following day, and since it is found that if food is left over it remains untouched subsequently until decomposition is complete.

Six separate fish of each sex formed minimum-fed groups and six of each sex maximum-fed groups, and the sizes of fish in each maximum-fed group were arranged to be as similar as was practicable. At the outset, minimum fish of as nearly as possible the same size as the maximum ones were employed. After a time the original minimum fish were in certain cases changed for larger fish, which were then kept on minimum rations. An attempt was thus made to ascertain the maintenance requirements of the freely growing fish, but difficulties were met with. A hasty substitution of fish meets with failure. For a variable period after capture, fish taken freshly from the sea refuse to feed, and lose weight to a considerable extent. It is better in practice to store such fish as are intended for later inclusion in the experiment as singly kept fish, in storage boxes in company with others of their kind. Newly captured fish which refuse to take food when kept alone, usually feed if kept with others of their kind.

It is very difficult to " match" freely growing fish with minimum fish. To do this a large number of "stored" fish of various sizes are required. There is considerable variation in the rate of growth of different individuals,

* This was the ruling of the officers of the Ministry of Agriculture and Fisheries. 
and one cannot predict the increase in length of any fish a fortnight in advance, and a fortnight or more is needed to allow freshly-trawled fish to become settled. It was not practicable to store large numbers of fish alive at Pier Cellars, and hence little success was obtained in attempts to "match" such fish as were already included in the experiment. But some success was met with in the general aim of determining the maintenance requirements of fish of different sizes.

Weighings were made fortnightly as in the case of the preliminary experiments. But each individual fish was separately treated, the weighing apparatus and its water contents being reweighed for every single fish.

The experiments proper commenced on May 22nd, 1929, but for a period of days previously a large number of fishes were fed and observed regularly, all apparently unsound individuals being removed. From the remaining fish a selection based upon size requirement was made. The experiments were continued until December 12th, 1929, although severely interfered with during the gales which occurred early in the month. In most cases the data obtained during the last fortnight of the experiments were rejected, and in other cases damage to the apparatus resulted in the loss of fish so that data were not forthcoming.

It must be mentioned that great care was taken throughout the course of the experiment to keep the boxes free of epifauna and epiflora. The small size of the perforations in the ebonite windows made it imperative to keep the boxes clear of sedentary forms of life of all kinds, in order to maintain a circulation of water through the boxes.

\section{RESULTS OF THE CAWSAND EXPERIMENTS OF 1929.}

\section{Minimum Requirements and Maintenance.}

Table 8 presents data obtained in experiments with a group of six male fish and a second group of six female fish, all kept separately and supplied with minimum rations from May 22nd to July 5th, a period of 44 consecutive days. During the period, four measurings and weighings were made, although in the table cited only the initial and final lengths and weights are given.

It is seen that, in males and females alike, the quantity of food necessary for purposes of maintenance varied in individuals of approximately the same size. Among the males, C4 lost $3.0 \mathrm{gm}$. in weight during the period when supplied with $0.43 \mathrm{gm}$., or 0.025 of the body-weight, of food per day. The fish C5, of smaller initial size, gained $3.0 \mathrm{gm}$. in weight when supplied with an almost identical average daily ration, while C3 maintained its weight constant (but increased its length) on $0.42 \mathrm{gm}$. of food per day. The mean fish increased its initial weight of $16.7 \mathrm{gm}$. by $1.7 \mathrm{gm}$. during 44 days, when supplied with $0.42 \mathrm{gm}$., or 0.024 of the body-weight, of food 
per day. Among the females, A2, A5, and A6 show some variation, while the mean fish increased its initial weight by $0.5 \mathrm{gm}$., when supplied with an average daily ration for the period of $0.42 \mathrm{gm}$., or 0.019 of the bodyweight of food. The increase in weight of the mean fish for the period is greater in the male group, so that the maintenance ratio is correspondingly smaller than the table indicates, approximating more closely to that of the female mean fish.

Data obtained from the experiments with the minimum-fed male fish C5a, C4a, and C6a from July 5th to November 28th, 1929, are shown in Tables 9, 10, and 11. The fish C5a lost weight during the early part of the experiment and never completely regained it, coming to within $1.0 \mathrm{gm}$. of its initial weight after 146 days. C4a and C6a also lost weight slightly during the early stages, but regained it and finally increased in weight slightly. The early loss of weight is due in all three cases to the fish's refusal to take food.

Inspection of Tables 9,10 and 11 will serve to show that the average daily ration can hardly be fixed so that the weight of the fish remains constant. For example, C5a, for the periods ending August 30th, September 16th, and October 1st, when sea temperatures were fairly uniform, gained $2.0 \mathrm{gm}$. in 14 days, $1.5 \mathrm{gm}$. in 17 days, and $1.0 \mathrm{gm}$. in 15 days when taking $0.64 \mathrm{gm}$., $0.66 \mathrm{gm}$., and $0.80 \mathrm{gm}$. of food per day for respective periods (Table 9). Similar examples of the apparent variation in maintenance requirements are shown in Tables 10 and 11. It appears impossible to supply a fixed daily ration for purposes of maintenance so that the body-weight of the fish will be maintained constant.

In Table 12 is shown how the ratio of food taken per day/average body-weight varied for the fishes $\mathrm{C} 5 \mathrm{a}, \mathrm{C} 4 \mathrm{a}$, and $\mathrm{C} 6 \mathrm{a}$ during the course of the experiment. The values of the ratio are calculated for each period and also cumulatively. Side by side with the data thus obtained are arranged the periodic increases in body-weight of the fish. The initial and final weights of a fish are shown on each side of the index of that fish. It is seen that for any fish, the slight increases in weight are disproportionate to the maintenance ratio, so that for the same fish a constant fraction of the body-weight of food per day will not serve to maintain the weight of the fish constant. Thus for C6a during the periods ending August 16th, August 30th, September 16th, and October 1st, when the maintenance ratio is $0 \cdot 023,0 \cdot 023,0 \cdot 022$, and $0 \cdot 020$, the increases in body-weight are $2 \cdot 0,-0 \cdot 5,1 \cdot 0$, and $0.5 \mathrm{gm}$. respectively. There is an appreciable fall in the value of the maintenance ratio during November, when the temperature of the sea-water of the pond falls. And it is seen also that the value of the maintenance ratio falls with increase in weight of the fish. Thus, the mean value of the ratio for the whole range of the experiments is $0 \cdot 019$ for $\mathrm{C} 5 \mathrm{a}$ and 0.016 for $\mathrm{C6a}$. This difference is rendered more conclusive 
when it is observed that the larger fish was able to increase its initial weight on the food supplied.

The results of the experiments with the minimum-fed female fish A4a, A6a, and A3a respectively, are shown in Tables 13, 14, and 15. As was found to be the case in males, the relationship between the quantity of food supplied to any fish per period and the slight increase in weight of the fish for the corresponding period, varies from time to time [compare the daily ration per period and the weight increase per period for periods ending August 16th, August 30th, September 16th, and October 1st, A4a (Table 13), A6a (Table 14), and A3a (Table 15)]. The same fact is emphasised when the daily maintenance ration is expressed as a fraction of the body-weight, as in Table 16. The variations in the ratio of food supplied per day to the average body-weight of the fish are not considerable, except during the early stages of the experiments when food was refused and for A3a during the period ending October 15th, but the differences in the increases in body-weight are well marked, e.g. during the periods between August 2nd and October 1st for the fish A6a.

The results shown in Table 16 do not show conclusively any appreciable fall in the value of the maintenance ratio with increased size of fish, but the fall in value of this ratio during November is admirably shown. Table 17 is compiled from Tables $9-16$, to show as nearly as is possible, and for the whole range of the experiments, how the maintenance requirements of fish of various sizes and of both sexes varied. It is seen that for fish of approximately the same size there is no appreciable differences of these requirements for the two sexes. Table 18 shows how the maintenance requirements of fish of various sizes varied for a relatively shorter period towards the end of the experiments and particularly how the value of the maintenance ratio diminishes as the sea temperature falls during November. It must not be overlooked that the increases in weight shown on the right are for a period of 14 days; those on the left for a period of 43 days.

A striking feature concerning growth in length is observed in the results of these experiments. Table 9 shows that for the whole range of the experiment with $\mathrm{C} 5 \mathrm{a}$, there was a loss of weight of $1.0 \mathrm{gm}$., although an increase in length of $0.4 \mathrm{~cm}$. For C6a from July 12th to October 1st, the weight decreased by $0.5 \mathrm{gm}$., while the length increased by $0.5 \mathrm{~cm}$. (Table 11). For the females A4a and A6a, during the course of the experiments to October 1st and September 16th respectively, the weights decreased by $1.0 \mathrm{gm}$., while the lengths increased by $0.5 \mathrm{~cm}$., in each case (Tables 13 and 14). It appears, therefore, that when loss of weight occurs, it is not usually accompanied by decrease in length, and that when weight is regained there occurs contemporarily an increase in length. The effect 
of this phenomenon is to lower the general condition of the fish as indicated by the weight/length ${ }^{3}$ ratio.* Thus, taking the female fish A4a, which lost $7 \cdot 0 \mathrm{gm}$. in weight during the period of 14 days ending July 19th (Table 13), the initial value of this ratio was $0 \cdot 010$. By July 19th the value had fallen to 0.008 and the initial value was never regained during the course of the experiment, the values for October 15th and November 27 th being $0 \cdot 009$. Similarly, the female fish A6a incurred a loss of weight of $3.5 \mathrm{gm}$. during the first fortnight of the experiment, and did not recover the initial value of the weight/length ${ }^{3}$ ratio $(0 \cdot 010)$ until November 27th, although consistently gaining in weight after the first loss. The male fish C5a did not show a value for the ratio as high as the initial one of 0.010 during the whole range of the experiment.

\section{Maximum Requirements and Growth.}

The results of the experiments with maximum-fed fish are varied. There was shown considerable variation in the rate of growth of different individuals, and in several cases failure was met with, where what appear to be abnormal fish made no appreciable growth whatsoever. The final results obtained with the six fishes of each sex are shown in Table 19. The total increases in size are indicated side by side with the total quantities of food consumed and the average daily rations for the whole period are shown. It is important to realise that references to food quantities are also references to appetite shown by the fish, since throughout the experiment, food lef $\iota$ over from a meal was consistently " weighed back" before the following meal was presented.

It will be agreed that certain fish can be excluded from consideration (Table 19). A 2-year old fish which increases its weight by $5 \cdot 0 \mathrm{gm}$. during 117 days, or $7 \cdot 0 \mathrm{gm}$. during 175 days, is not progressing satisfactorily. The fish B3 showed signs of inability to co-ordinate movements, swimming inverted and settling down on the vertical faces of the box as if on the floor of it. Accordingly, such fish as D6, B3, and B5 will be disregarded. In the D group, D3 made most progress, and will receive special consideration as showing the maximum growth for the experiments. The fishes D2 and D4 will be compared with D3. In the B group, B1 and B4 show the maximum growth for the experiment, and B2, B5a, and B6 will be compared with them.

It is seen from Table 19 that the average quantity of food consumed per day for the whole range of the experiments is about $3 \cdot 3 \mathrm{gm}$. for the fish showing maximum growth, males and females alike. The weight of

* The constant $\mathrm{K}$, which is a measure of the general condition of a fish, is usually defined as $\frac{W \times 100 .}{L^{3}}$. Here it is taken as $\frac{W}{L^{3}}$. 
food necessary to produce $1.0 \mathrm{gm}$. of fish, estimated for the whole range of the experiment works out as follows :

$$
\begin{aligned}
& \text { D3 }(\hat{\jmath})-6 \cdot 6 \mathrm{gm} . \\
& \text { B1 (ㅇ) }-7 \cdot 6 \mathrm{gm} . \\
& \text { B4 (ㅇ) }-7 \cdot 2 \mathrm{gm} .
\end{aligned}
$$

In these instances, therefore, the efficiency of the male appears to be greater than that of the female, contrary to the findings during the preliminary experiments. For all fish, good, bad and indifferent, and for the whole range of the experiment, $11.6 \mathrm{gm}$. of food produces $1 \cdot 0 \mathrm{gm}$. of mean male fish and $13.9 \mathrm{gm}$. of food produces $1.0 \mathrm{gm}$. of mean female fish, so that here again the male appears to possess greater efficiency.

The data concerning the male fish D3 are shown in Table 20. It is seen that increases in body-weight for any specified period reach a maximum during September. This is also shown in the acceleration curve (i.e. a curve showing the increase or decrease in value of periodic increments from time to time, or in other words, showing the rate of change of growth) of body-weight in Fig. 5. The quantity of food consumed per day is a maximum during early October, but is near its maximum value during September, as is also shown in Fig. 5. The general condition of the fish as indicated by the value of the weight/length ${ }^{3}$ ratio, is at its best when the appetite of the fish is greatest and when maximum growth is taking place, as would perhaps be anticipated.

Periodic increases in body-weight are shown in Fig. 5 in the form of an acceleration curve, while the growth curve of weight is shown above. The latter is seen to be a smooth, slightly asymmetrical, sigmoid curve of typical form. The steepest part occurs during mid-September, and the point of inflection for the season is not reached at the close of the experiment. No attempt has been made to find the equation to this singlefish curve.

It is also seen from Table 20 that the efficiency of the fish, as expressed by the quantity of food necessary to produce $1.0 \mathrm{gm}$. of fish, varies from period to period during the course of the experiment. The efficiency is greatest during September, when the weight increments of growth are greatest, when $4.8 \mathrm{gm}$. to $4.9 \mathrm{gm}$. of food are required. Thus it is indicated that factors other than merely the quantity of food consumed operate. There is a period of increased efficiency during early July, and it is worthy of remark that two peaks occur on the temperature graph for the season which closely correspond with these periods. The efficiency of the fish estimated to any date varies between $5 \cdot 6 \mathrm{gm}$. and $8.8 \mathrm{gm}$. of food per $\mathrm{gm}$. of fish over the initial weight.

Growth in length of the male fish D3 appears to be a linear function of time, at least for the major part of the experiment, as is shown by 
inspection of the figures given for length in Table 20. Plotting length against time, we obtain the curve shown in Fig. 9. Until the middle of October, the points plotted arrange themselves evenly and fairly closely about a perfectly straight line.

The results of the experiment with the male fish D2, which are shown in

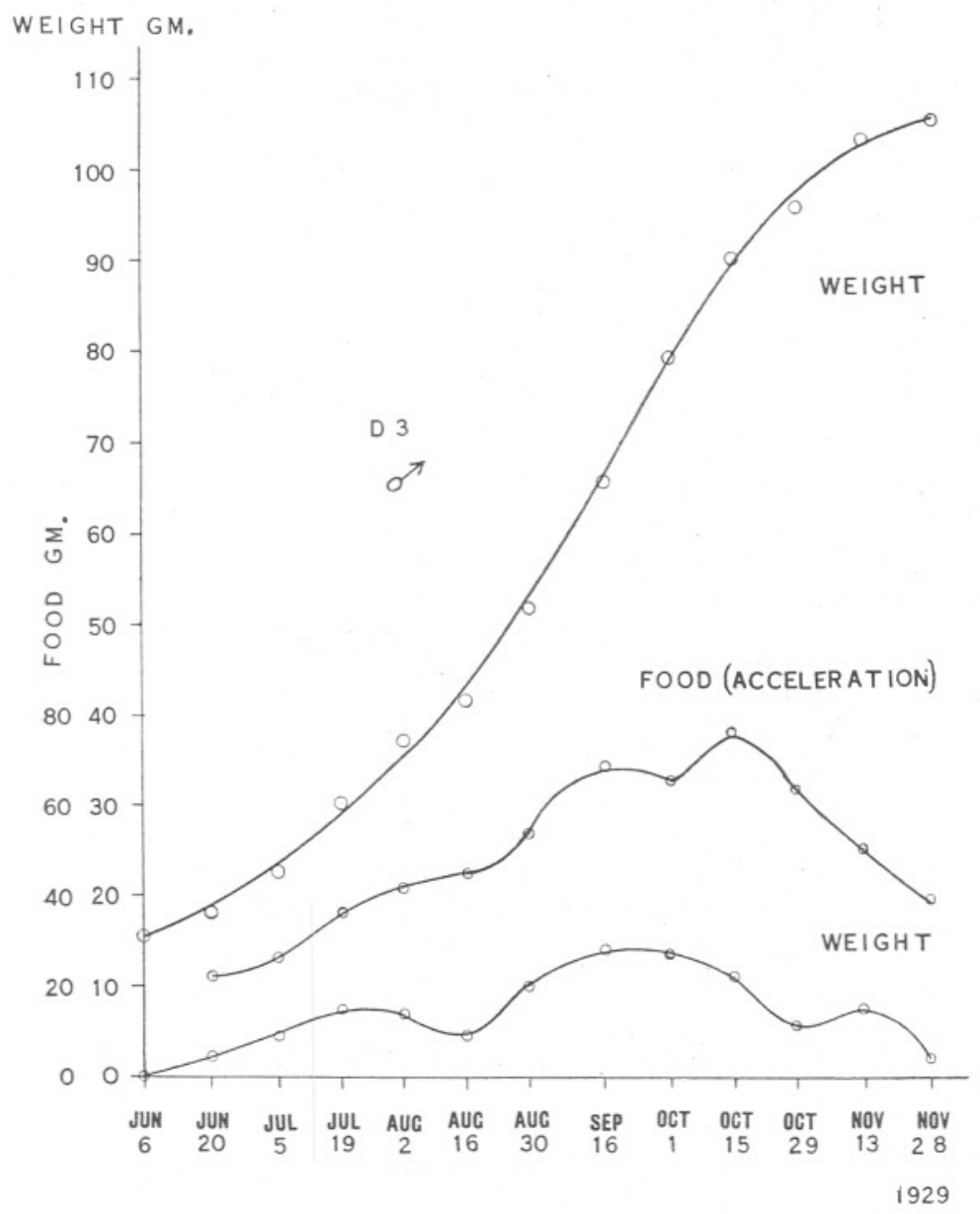

Fig. 5.-Growth curve of weight of the male plaice D3 together with acceleration curves of periodic body-weight and food-weight increments. (Cawsand, 1929.)

Table 21, are distinctly interesting. As in the case of D3, the quantity of food consumed per day reaches a maximum during late September, when the condition of the fish, as indicated by the weight/length ${ }^{3}$ ratio, was at its best. But growth in weight is not at all regular, and the efficiency of the fish varies in a striking manner (see Column 8, Table 21). During July 
there is an acceleration of growth in weight (Table 21 and also Fig. 6), then during August a retardation, followed by a great acceleration during the early part of September. There is here a strong suggestion that growth in weight is connected with temperature, the two accelerations in growth coinciding with peaks on the temperature graph (Fig. 11), the retardation with a fall in temperature during August. The curve of growth in weight (Fig. 6) suggests that this fall in temperature interfered in some way with the metabolic processes of the fish and that growth was slowed down

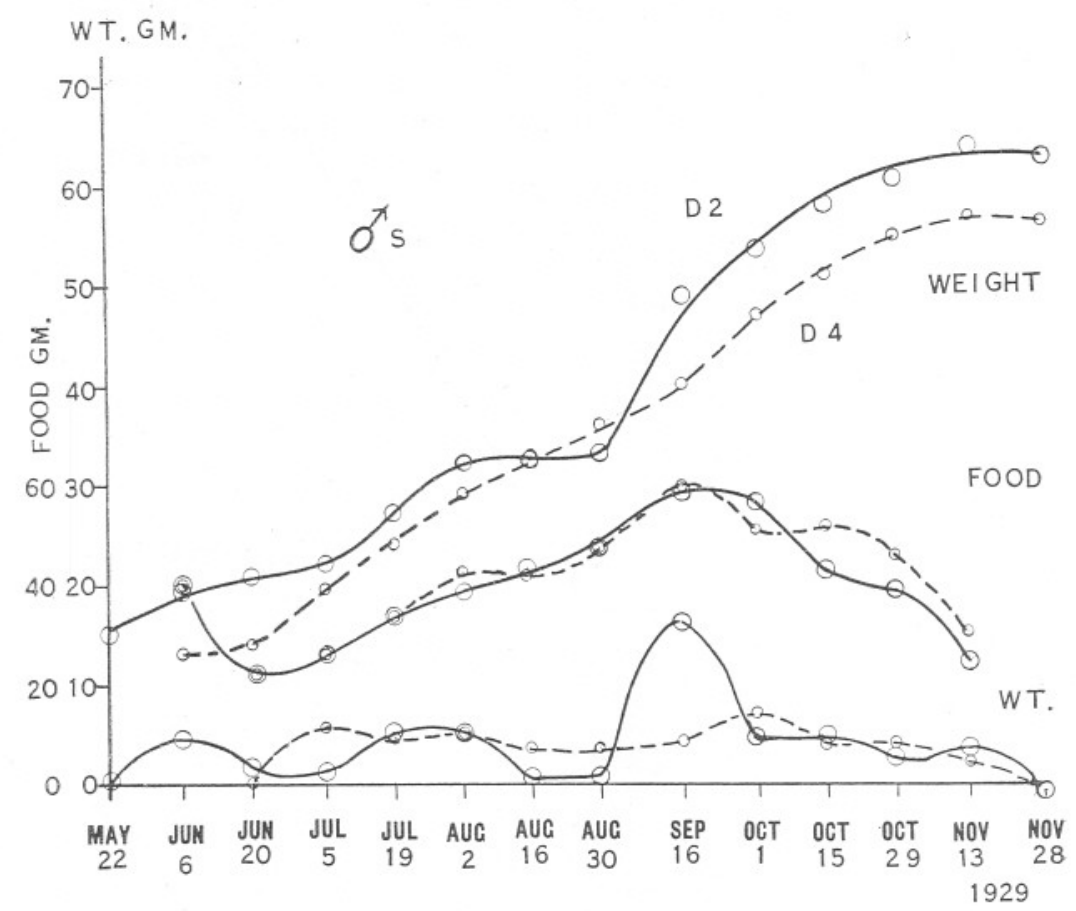

FIc. 6.-Curves of weight and acceleration curves of body-weight and food increments for the male fishes D2 and D4. (Cawsand, 1929.)

until the great acceleration during September, which proved too late to produce a typical result such as was shown by the fish D3. The efficiency of the fish D2 during early September, when $3.6 \mathrm{gm}$. of food produced $1.0 \mathrm{gm}$. of fish, is truly remarkable. It greatly transcends that of D3 for any period during the year, although the appetite for food after the first fortnight was never as great as in the latter fish.

The growth in weight of D4 follows that of D2 fairly closely. The total increase in weight for the whole period (Table 22) is comparable with that shown by D2, as is also the total quantity of food taken, and therefore the average efficiency of the fish. But in the case of D4, there 
is no phenomenal acceleration of growth in weight. Instead, growth is more regular, but attains a maximum during late September. There is shown a slight retardation of growth during August, which is comparable with the more marked one shown by D2 (Fig. 6).

A consideration of the growth of the male plaice D3, D2 and D4 shows

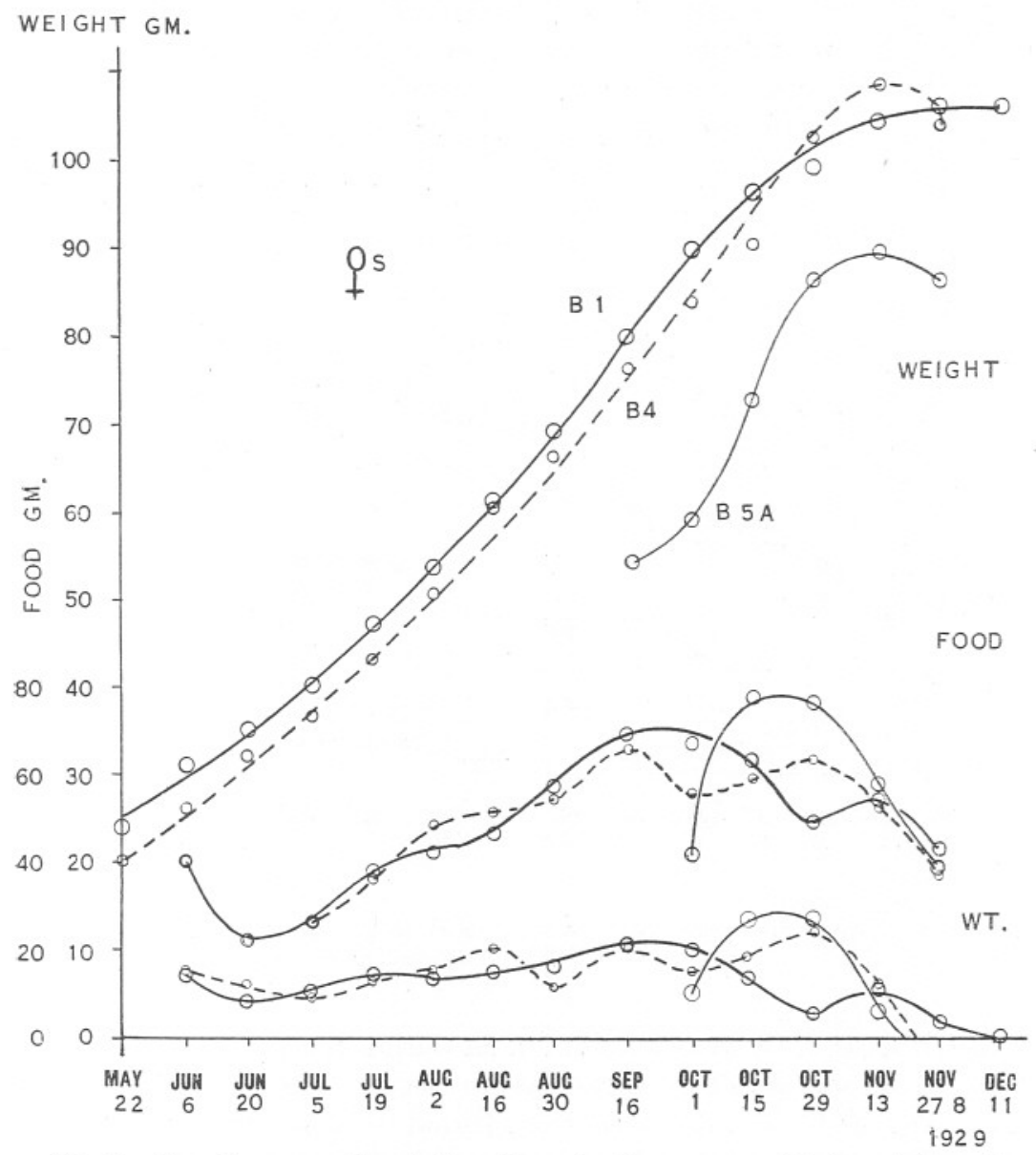

FIG. 7.-Growth curves of weight and acceleration curves of body-weight and food-weight for the female fishes B1, B4 and B5a. (Cawsand, 1929.)

then that September is the month of greatest appetite and maximum growth. It is also apparent that temperature influences growth and that, given a suitably high temperature, fish which have suffered a retardation of growth are able to become increasedly efficient in an attempt to compensate for the growth inhibition.

It has been observed above that the growth taking place in female 
fish closely follows that in the male fish, for individuals showing the maximum growth for the experiments. The females B1 and B4 show a very close agreement and can be considered side by side. Table 23 presents the data concerning B1, Table 24 that concerning B4. In the case of B1, the maximum growth in weight occurs during September, when over $20 \mathrm{gm}$. are added to the body-weight. In the case of B4, growth is accelerated during September, but attains a maximum during October, when over $18.5 \mathrm{gm}$. are added to the body-weight. In each case maximum growth is accompanied by maximum appetite. In the case of B1, the

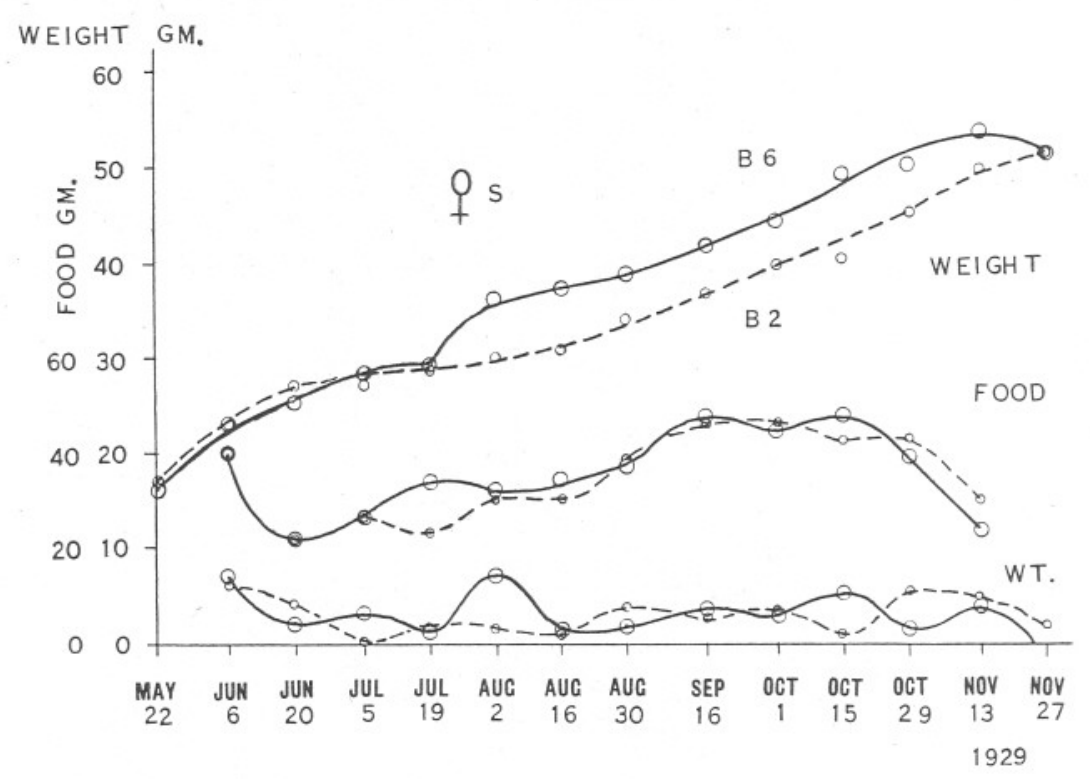

FIG. 8.-Growth and acceleration curves of body-weight and food-weight for the females B6 and B2. (Cawsand, 1929.)

weight/length ${ }^{3}$ ratio is also a maximum during the period of maximum growth. As was found to be the case in the male fish D3, the efficiency of the females B1 and B4 varies from period to period during the growth season, but there is no marked increase in efficiency when growth and appetite attain maximal values.

The curves of growth in weight of the females B1 and B4, like that of the male D3, are sigmo:dal in form (Fig. 7). During the first half of the experiment the curves follow each other closely, but differences are shown towards the end of the period. The point of inflexion of the curve for B4 is reached in mid-November, while that of the curve for B1 may be considered as reached during early December. The acceleration curves of food and body-weight increments for the fish B1 and B4, shown in Fig. 7, suggest that there is some connexion relating them, 
despite the periodic variations in efficiency indicated from period to period.

The curves of growth in length of the fishes B1 and B4 are shown in Fig. 9, side by side with the corresponding curve for the male D3. It is seen that, as in the case of the male, this curve is a straight line one for the early part of the experiment in each case, and that the curves for the female

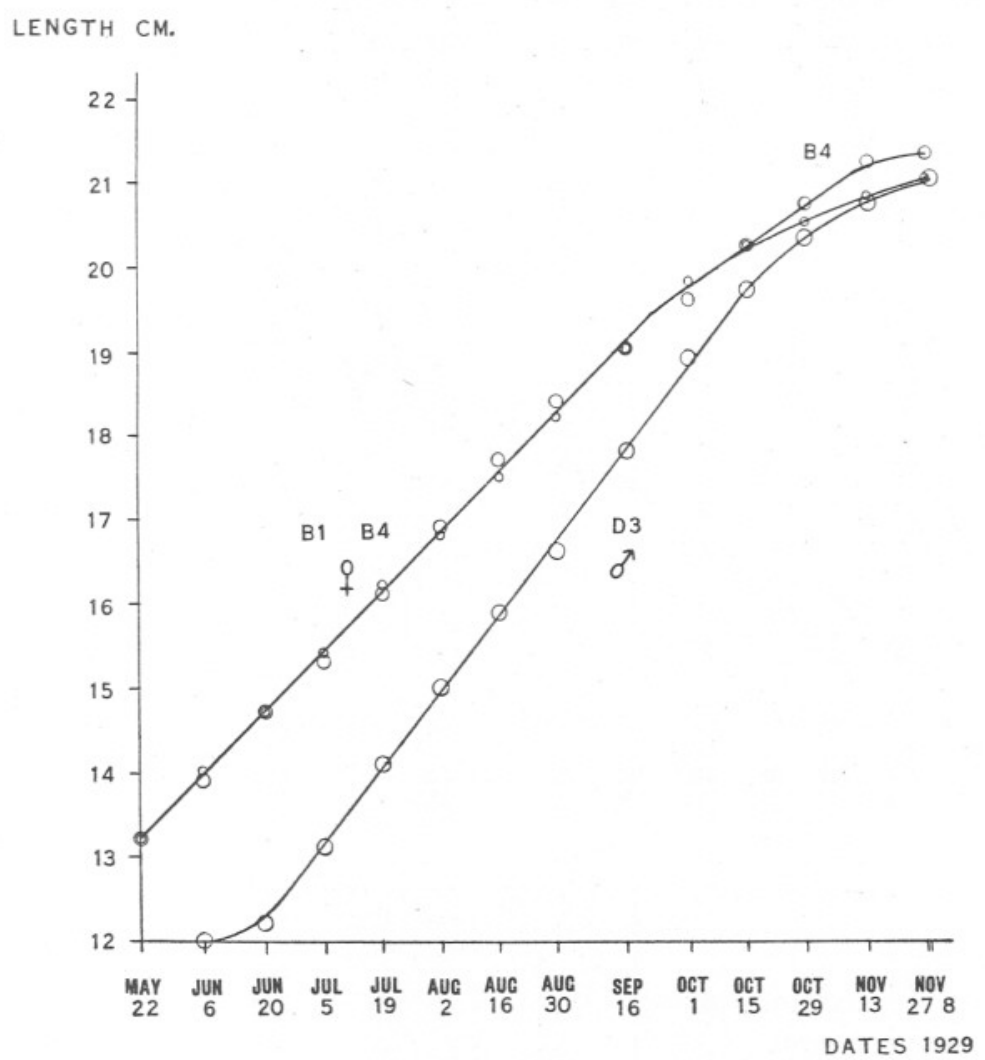

FIg. 9.-Growth curves of length for the male D3 and the females B1 and B4. (Cawsand, 1929.)

are very similar. The slopes of the B1, B4 curves are less steep than that for the D3 one. Even during the latter parts of the experiments, the relationship between length and time appears to be a linear one, a straight line with a lesser slope being obtained.

On September 17th the female fish B5a was substituted for an unsatisfactory fish B5, and the data concerning the substituted fish are shown in Table 25. The curve of growth of this fish, together with acceleration curves for body-weight increase, and food increments is shown in Fig. 7. 
This fish is especially interesting in that it shows a remarkable acceleration of growth in weight during October, together with a greatly increased appetite for food and a rapid improvement of the general condition as indicated by the weight/length ${ }^{3}$ ratio. The body-weight of this fish was increased during October by more than $27 \mathrm{gm}$., and during this month it consumed at least $1.0 \mathrm{gm}$. of food per day more than the fishes B1 and B4, at the same time showing an increased efficiency over these fish. The point of inflexion of its growth curve was reached very shortly after the

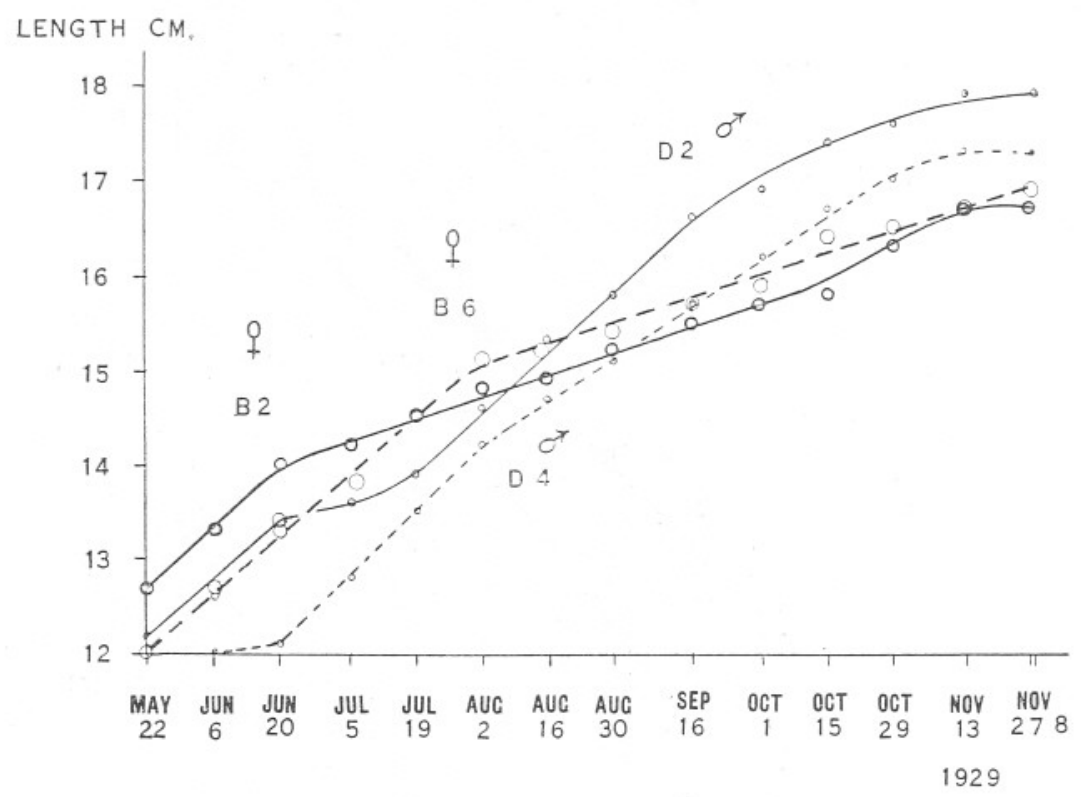

Fia. 10.-Growth curves of length for the males D2 and D4 and the females B2 and B6. (Cawsand, 1929.)

period of maximum growth and towards the end of the experiment it was losing weight.

Growth occurring in the fishes B2 and B6 during the earliest periods of the experiments compares closely with that occurring in the fishes $\mathrm{B} 1$ and B4. They gained substantially in both length and weight (Tables 26 and 27 ), and improved in general condition. But both received setbacks which inhibited growth and from these never completely recovered, although B2 made attempts during late August and September, B6 during late July and early October. B6 maintained a good general condition, as measured by the weight/length ${ }^{3}$ ratio, throughout. The growth curves and acceleration curves of body-weight and food increments are shown in Fig, 8 .

The growth curves of length for the females B2 and B6 are shown in 
Fig. 10 along with those for the males D2 and D4. Taking B2 first, it is seen that inhibition of growth in length took place during late June, after a short period of what appears to have been typical growth. This inhibition of growth in length is paralleled by a corresponding inhibition

TEMPERATURES
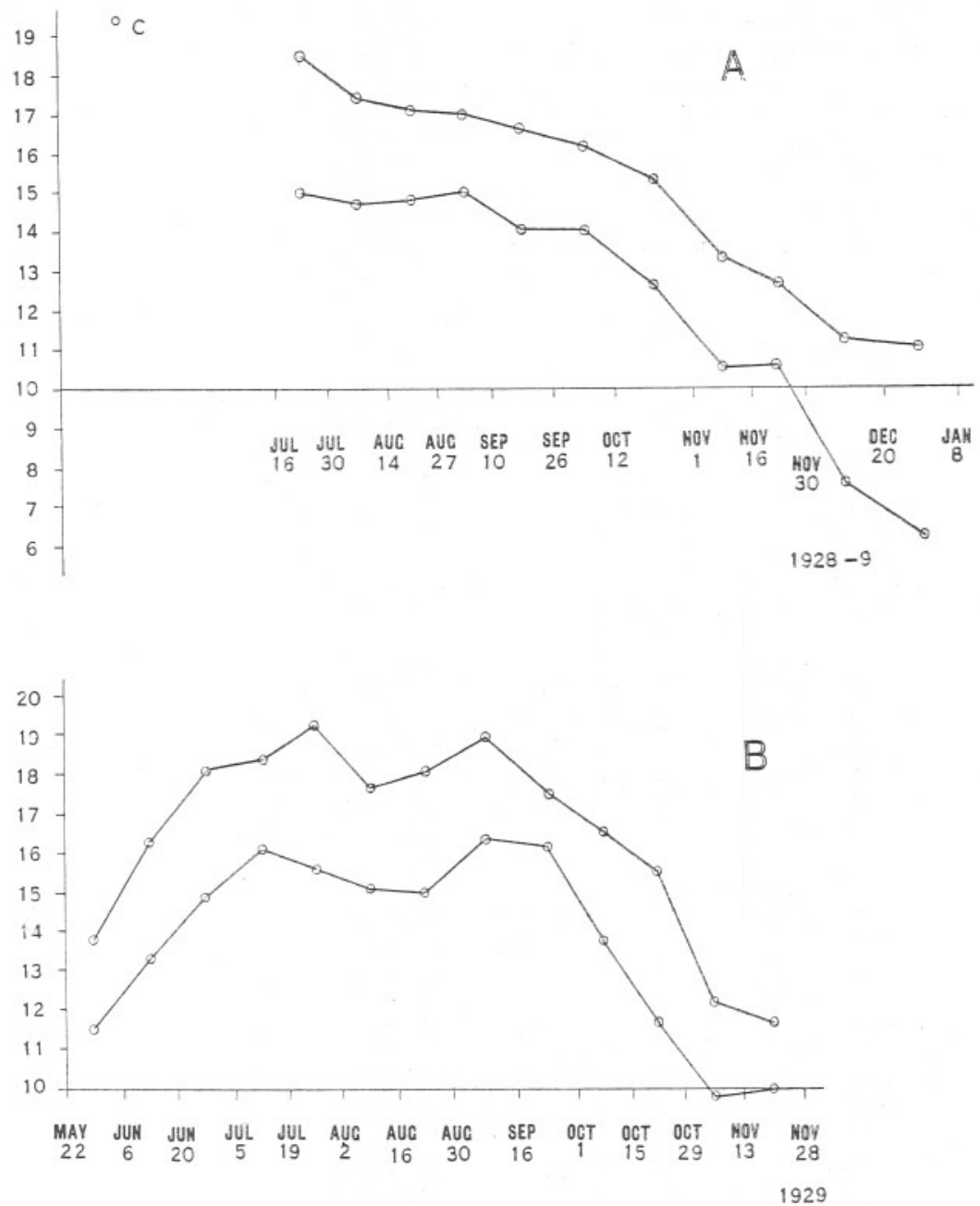

FIG. 11.-Graph of maximum and minimum temperature at Cawsand. [A] 1928-29; [B] 1929.

shown by the male D2. A difference is seen to follow the inhibition. Whereas in B2 the inhibition is permanent, the relationship between growth in length and time continuing to be a linear one yet a different one as shown by the change in the slope of the curve (Fig. 10), that in 
D2 is temporary, the old linear relationship being continued at least until mid-September. These characteristics are also shown by the curves of growth in weight, D2 - Fig. 6, and B2-Fig. 8. The inhibition of growth in weight shown by the male fish D2 during the month of August and attributable to a fall in temperature is not accompanied by inhibition of growth in length, the same linear relationship between growth in length and time obtaining throughout, from mid-July to mid-September. The case of the female B6 is different, however. Growth in both length and weight is typical until August, after which growth inhibition occurs in both respects (Figs. 10 and 8 ). This inhibition may be attributed to fall in temperature of the sea-water in the pond. It thus appears that growth in both length and weight is influenced by temperature.

A temperature graph for the 1929 experiments is shown in Fig. 11 (B). A similar graph for the preliminary experiments of 1928 is also shown (A).

\section{Conclusions Drawn from the Experiments of 1929 (Cawsand).}

(1) A mean male fish $12 \cdot 7 \mathrm{~cm}$. in length and $16 \cdot 7 \mathrm{gm}$. in weight was able to maintain itself and also to increase its weight by $1.7 \mathrm{gm}$. during 44 days from May 22nd, 1929, on an average daily ration of $0.43 \mathrm{gm}$. of Mytilus flesh. The maintenance ratio, i.e. the ratio of food consumed per day/average body-weight, approximates to $0 \cdot 025$, but it is suggested that this value is high as is shown by the slight increase in weight. A more accurate value would approximate more closely to the value obtained for the mean female fish (vide infra).

(2) A mean female fish $13.6 \mathrm{~cm}$. in length and $22 \cdot 1 \mathrm{gm}$. in weight gained $0.5 \mathrm{gm}$. in weight during the period stated above, when it consumed an average daily ration of $0.42 \mathrm{gm}$. of food, or $0 \cdot 019$ its average body-weight.

(3) The average daily ration of food required to maintain the weight of any male or female fish constant appears to vary from period to period during the course of the experiments.

(4) The ratio of food required per day for purposes of maintenance/ average body-weight of a fish appears to vary in different fish. In general it tends to fall in value with increase in size of the fish.

(5) The maintenance requirements of any fish appear to diminish appreciably during late October and November, and the fall is synchronous with fall in temperature of the sea-water.

(6) Loss of weight shown by any fish is not generally accompanied by decrease in length, and the regaining of weight is accompanied by 
increase in length. The results of such loss of weight may be shown in the lowered general condition of the fish, as indicated by the weight/length ${ }^{3}$ ratio, for months following the loss, even though a slight food allowance is available for purposes of growth.

(7) The growth curve of weight of fully-fed male and female fish is sigmoidal and asymmetrical. The maximum acceleration of growth in weight appears to occur during late September, when appetite for food is also a maximum. The efficiency of a fish, as measured by the quantity of food required to produce $1.0 \mathrm{gm}$. of fish, varies from time to time. In the male fish the greatest efficiency obtains when growth and appetite attain maximal values.

(8) Growth in length of male and female fish alike is an arithmetical function of time. The relationship holds good for the period of most rapid growth during the season.

(9) Growth inhibition may be followed by a strikingly increased acceleration of growth, when the fish displays a greatly enhanced efficiency. Appetite may be increased tremendously at the same time.

(10) Temperature appears to influence growth directly. Thus a fall in temperature may induce an inhibition of growth in both length and weight. If an increase in temperature follows the inhibition is overcome, other things being equal, and growth acceleration occurs. But such inhibition may also be rendered permanent for the growth season considered.

\section{RESULTS OF THE LYMPSTONE EXPERIMENTS OF 1929.}

\section{Introduction.}

A series of experiments similar to the revised experiments of Cawsand was carried out at the Ministry of Agriculture and Fisheries Mussel Tanks at Lympstone in the estuary of the River Exe, commencing on June 24th, 1929, under the care of Mr. H. Lees, Tank Superintendent. The boxes used were made at Cawsand and were identical with those used in the revised Cawsand experiments. They were suspended in the large tank A. The methods employed were precisely the same as those employed in the Cawsand experiments, and the same precautions were taken in weighing back food left over from any meal. Mr. Lees also kept temperature records of the water daily. The data obtained from the experiments were handed over to me by Dr. E. S. Russell in order that a comparison could be afforded of the two series of parallel investigations. 


\section{Mínimum Requirements and Maintenance.}

The results of the experiments on minimum requirements and maintenance with the male fishes, L1, L4, L3 and L2 are shown in Tables 28, 29, 30 and 31. It is seen that in all cases, excepting that of L4b, there is a slight loss of weight during the early stages of the experiments, but that in all cases the lost weight was regained and slight increases of weight occur.

The average quantity of food taken per day by the male fish L1 during periods included between September 16th and November 25th is seen to have been fairly constant (Table 28), but the weight of the fish varies during successive periods. For the periods ending September 30th, October 14th and November 11th approximately $0.95 \mathrm{gm}$. of food allows of an increase in weight. For the periods ending October 28th and November $25 \mathrm{th}, 0.90 \mathrm{gm}$. of food per day results in a slight loss of weight. Thus, between $0.90 \mathrm{gm}$. and $0.95 \mathrm{gm}$. per day appears to be a measure of the maintenance requirements of this fish. For the whole range of the experiment to November 25th (and it is not until slightly later than this that both maximum and minimum temperatures fall below $10^{\circ} \mathrm{C}$.), $0.90 \mathrm{gm}$. of food per day allows of an increase over the initial weight of $3.8 \mathrm{gm}$. during 95 days. The average weight of the fish has been $52 \cdot 2 \mathrm{gm}$.

L4a, a fish of $84.7 \mathrm{gm}$. weight, loses weight on $0.85 \mathrm{gm}$. of food per day, which, judging according to the requirements of L1, seems an inadequate daily ration. However, for a period of 14 days, $0.88 \mathrm{gm}$. of food per day allows of a slight increase in weight (Table 29). The slightly smaller fish, L4b, to November 25th, loses weight if the daily ration falls below $1.0 \mathrm{gm}$. (and in one case when it is as high as $1.30 \mathrm{gm}$.). For the whole range of the experiment to November 25th, an average daily ration of $1.11 \mathrm{gm}$. of food allows of a slight increase in weight ( $1.8 \mathrm{gm}$.).

L3, with an initial weight of $105 \cdot 3 \mathrm{gm}$., loses weight if less than $1 \cdot 30 \mathrm{gm}$. of food is taken daily per any fortnightly period, and gains weight if more than $1.38 \mathrm{gm}$. is taken (Table 30). For the whole period to November 25th, a daily ration of $1.32 \mathrm{gm}$. of food allows of an increase in weight of $4 \cdot 1 \mathrm{gm}$. During this period, 78 days, the fish has taken ápproximately its own weight of Miytilus flesh.

L2 suffers loss in weight when the daily ration for any fortnightly period to November 25th is less than $1.30 \mathrm{gm}$., and gains in weight if this ration is over $1.66 \mathrm{gm}$. Taking the whole range to November 25th, $1.44 \mathrm{gm}$. of food per day results in a loss of $0.5 \mathrm{gm}$. from the initial weight of $129 \cdot 9 \mathrm{gm}$. (Table 31).

In Table 32 are shown the results of two shorter range experiments, which do not appear to conform to those of the longer range experiments mentioned above. The maintenance requirements of Lla appear 
especially to be relatively low ones, those of L2a high ones taking the loss of weight into account (cp. with L1, Table 28).

In Table 33, the daily rations supplied to the male fishes L1, L4b, L3 and L2 are shown as fractions of the average body-weight. The order presented is one of increasing body-weight from left to right, initial and final weights being shown on each side of the fish index. The maintenance ratio is shown for each fortnightly period and also cumulatively from the commencement of the experiment. For L1 the value of the ratio for periods from August 19th to November 25th varies between 0.015 and $0 \cdot 019$. For L4b the corresponding variation is from $0 \cdot 010$ to $0 \cdot 018$, for L3 from $0 \cdot 010$ to $0 \cdot 015$ and for L2 from $0 \cdot 009$ to $0 \cdot 014$. Thus the range tends to become lowered with increase in size of the fish. If the whole period to November 25th be taken, the values of the ratio for these fish, taken in the order presented above, are $0 \cdot 017,0 \cdot 015,0 \cdot 012$ and $0 \cdot 011$. The accuracy of the last figure is open to some doubt being slightly beyond the accuracy of the weighings, but the argument is not thereby robbed of its force, especially as the values given are all subject to the same errors. Thus there appears reasonable proof of the fall in value of the maintenance ratio with increase in size of the fish. The same conclusion is reached if the values for the daily rations, estimated to November 25th, are plotted against the body-weight of corresponding fish.

For female fish the results are similar to those of males. Neglecting for the moment results obtained after November 25th, L5 shows a loss in weight if the average daily ration falls below $0.81 \mathrm{gm}$. (except in one instance), and an increase in weight if it is $0.81 \mathrm{gm}$. or over (Table 34). To November $25 \mathrm{th} 0 \cdot 88 \mathrm{gm}$. of food per day results in an increase over the initial weight $(62 \cdot 8 \mathrm{gm}$.) of $4 \cdot 1 \mathrm{gm}$. L6 (initial weight, $71 \cdot 2 \mathrm{gm}$.) loses weight when the daily ration falls as low as $1 \cdot 1 \mathrm{gm}$. and gains weight if it is over $1.2 \mathrm{gm}$., except during late November. To November 25th an average daily ration of $1 \cdot 19 \mathrm{gm}$. results in a slight loss of weight $(1 \cdot 1 \mathrm{gm}$.) (Table 35). L7 (initial weight, 104.8 gm.) suffers loss of weight if an average quantity of food less than $1.4 \mathrm{gm}$. per day is taken, except during November, and to November 25 th loses $4 \cdot 2 \mathrm{gm}$. in weight after having consumed an average daily food ration of $1.32 \mathrm{gm}$. (Table 36). L8a (initial weight, $102 \cdot 0 \mathrm{gm}$.) requires approximately $1 \cdot 3 \mathrm{gm}$. of food per day, while L8b (initial weight, $114 \cdot 0 \mathrm{gm}$.) loses $0 \cdot 4 \mathrm{gm}$. in weight on an average of $1.51 \mathrm{gm}$. of food per day (Table 37 ).

The average daily rations of the female fishes mentioned above are shown as fractions of the average body-weight in Table 38. Estimates are shown for each fortnightly period, and also cumulatively from the commencement of the experiments. The fall in value of the maintenance ratio with increasing size of fish is not as well marked as in the case of males, but is shown all the same. To November 25 th the values, taken 
for increasing sizes (left to right, Table 38) are $0 \cdot 014,0 \cdot 017,0 \cdot 013$ and $0 \cdot 013$. The fishes L5 and L6 are of approximately the same size and these results show the likelihood of considerable individual variations in maintenance requirements.

The results of shorter range experiments are presented in Table 39. The smallest female, like the smallest male, requires a relatively high average daily food ration. This is also shown in Table 40, where it is

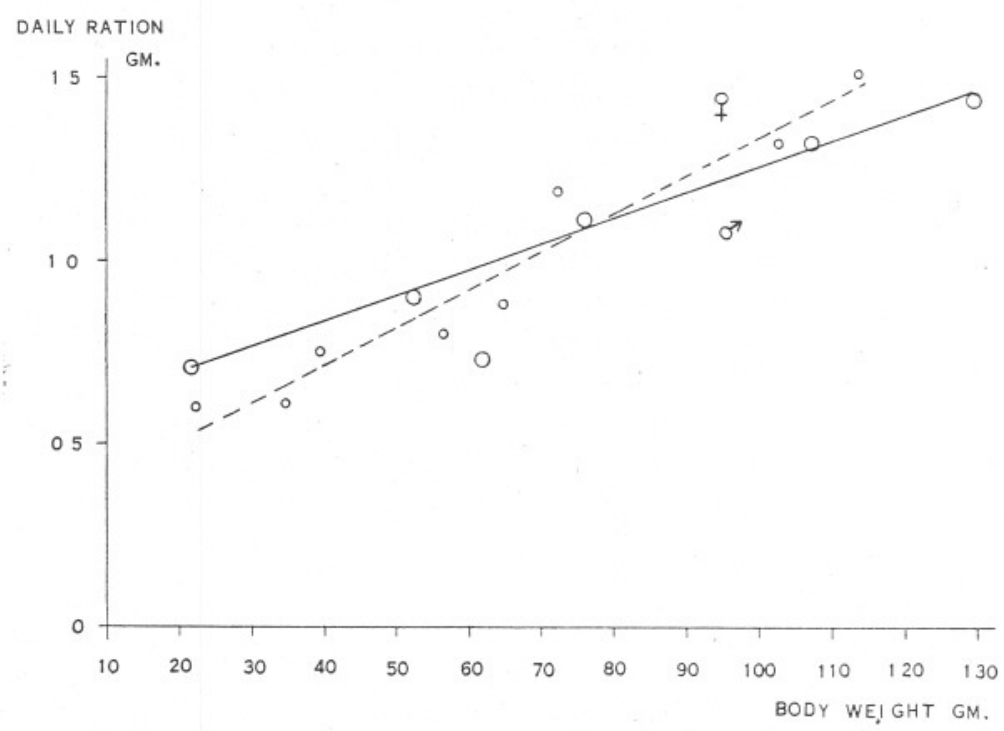

FIG. 12.-Graph showing the variation in maintenance requirements with size of fish. The abscissæ represent body-weights, the ordinates values of daily rations for purposes of maintenance. (Lympstone.)

also seen that despite considerable variations, there is a decrease in value of the maintenance ratio in larger fish.

Fig. 12 attempts to show graphically the relationship between the size of various fish and their maintenance requirements. These values are taken from preceding tables, and represent averages to November 25th except in the lower part of the graph where values from Tables 32 and 39 are employed. The points plotted are :

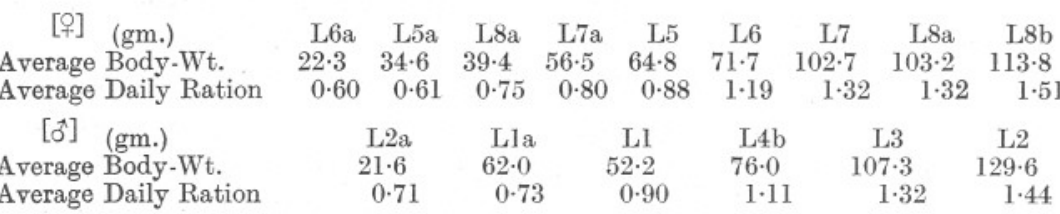

It is seen that the value of the ratio probably falls off with increasing size of fish, more rapidly in males than in females. 


\section{Maximum Requirements and Growth.}

The final results of the experiments on maximum requirements and growth at Lympstone are summarised in Table 41. As in the Cawsand experiments, considerable variation is shown in the growth of different individuals. One male (L11) made great progress, while two females made very satisfactory efforts to rival this male. The average quantities of food taken per day vary considerably, and for the fish displaying the most rapid growth-rate the quantity is slightly more than $6 \mathrm{gm}$. per day. It is surprising to note that this average daily ration is almost twice as great as that consumed by the most actively growing fishes at Cawsand $(3 \cdot 3 \mathrm{gm}$. per day). Growth was correspondingly greater at Lympstone, but the efficiency of the Cawsand fish was slightly greater, in male and female alike. At Lympstone the male again appeared to be rather more efficient than the female.

Data concerning the experiment with the male fish L11 are shown in Table 42. Maximum growth takes place during August although the increments added to the weight of the fish during September and October are almost as great as those for August.* This is also shown in the acceleration curve for body-weight increase increments (Fig. 13). The general condition of the fish, as shown by the weight/length ${ }^{3}$ ratio, is best during October and November, and better than was found in any instance at Cawsand. The appetite of the fish is greatest during late September and early October, when the efficiency of the fish is near its maximum value, and the maximum daily ration on the average for the experiment is $7.5 \mathrm{gm}$. It is noteworthy that this fish took from $7 \cdot 0 \mathrm{gm}$. to $7.5 \mathrm{gm}$. of food per day consistently from July 22 nd to October 14th, i.e. there are no peaks on an acceleration curve of food increments such as are found on the corresponding curve for increments of increase in body-weight. The efficiency of the fish varies considerably from time to time, which suggests that there is no continuous direct relationship between the quantity of food consumed and growth in weight. Growth in length appears to follow a linear relationship with time (Fig. 14), and it appears strange that the curve for growth in weight is representable as a straight line curve to November 11th, when inhibition takes place (Fig. 13).

The male fish L10 barely doubled its initial weight during 98 days (Table 43), consuming 9 times the average body-weight for the whole period of food. Maximum growth occurred during July, but the best general condition obtained during late August, when the appetite was greatest and the efficiency low. The curve of growth in weight is shown in Fig. 13. And L9 did not succeed in doubling its initial weight although it consumed $8 \frac{1}{2}$ times its average body-weight for the whole range of the

\footnotetext{
* The increase in weight for July 8 th is neglected.
} 
experiment (Table 44). Maximum growth obtained in this fish during late July and early August and here, when appetite was a maximum, efficiency was very low. The growth curve of weight is shown in Fig. 13. The male fish L12 displayed a greater average growth-rate (Table 45).

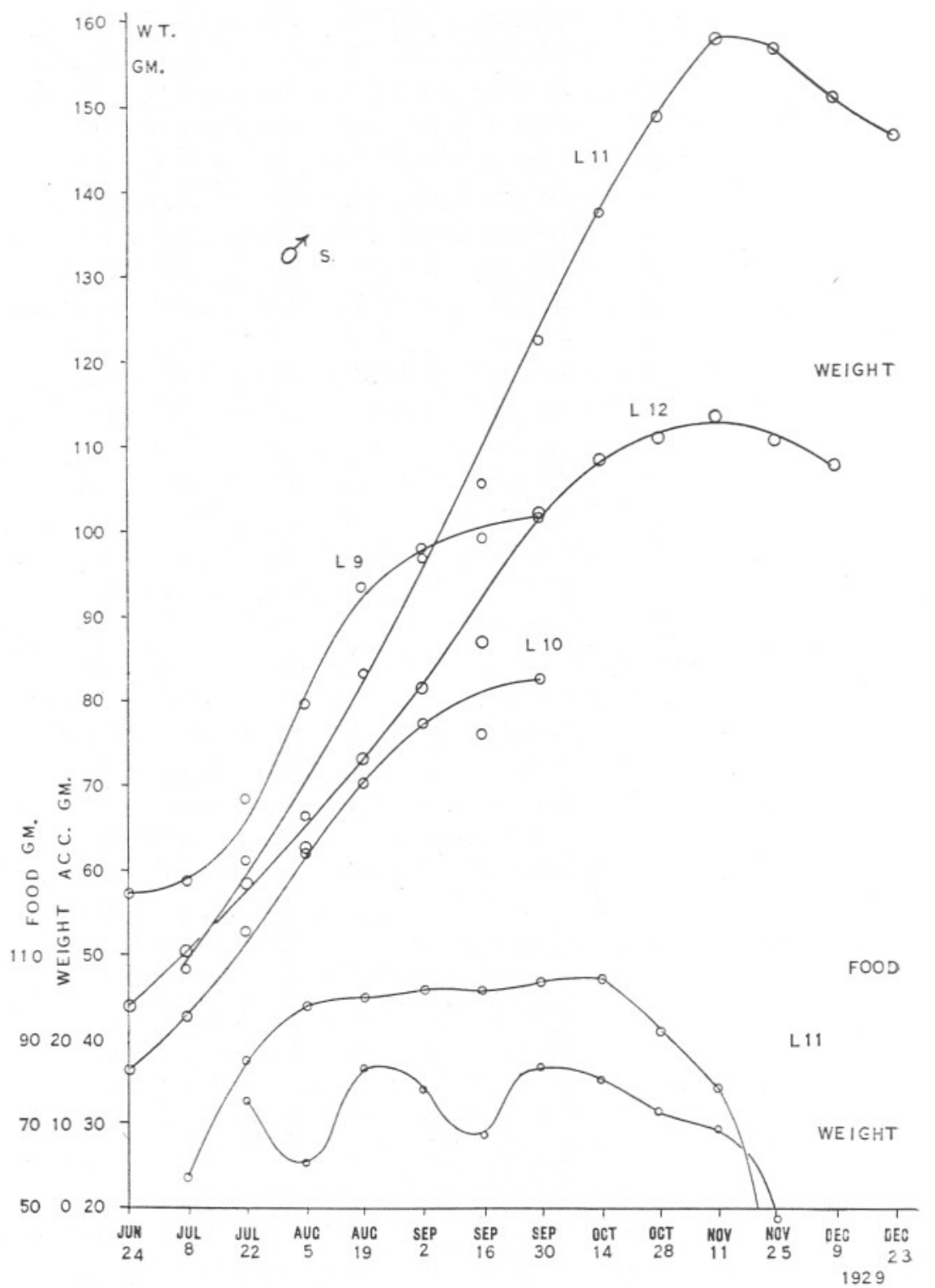

Fig. 13.-Growth curves of weight for the males L9, L10, L11 and L12, together with acceleration curves of food and body-weights. (Lympstone.) 
Maximum growth in weight occurred during September, although growth was also rapid during August. The efficiency of the fish varied considerably, and was high during early August and late September. During the latter period the general condition was at its best. The curve of growth is shown in Fig. 13.

Among the females, L15 progressed well. The final weight at the point

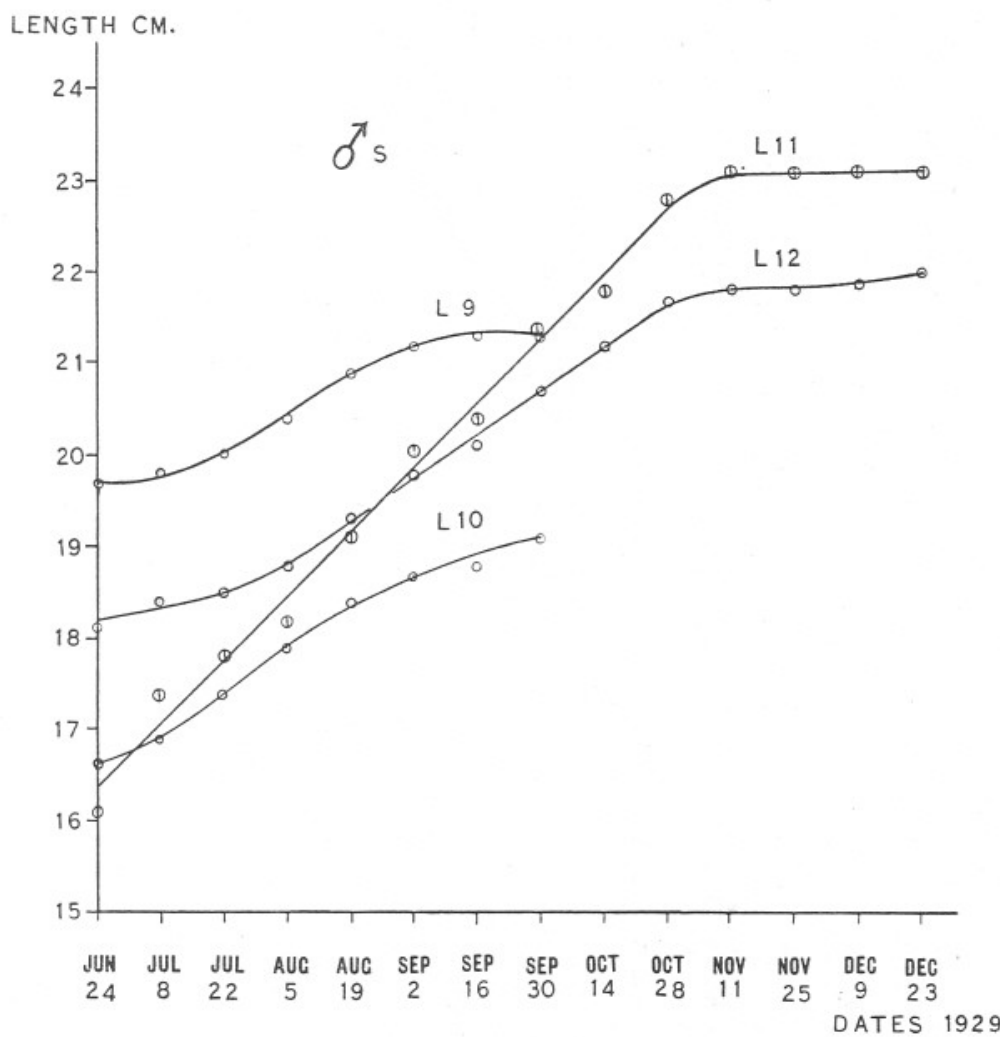

FIG. 14.-Growth curves of length for the males L9, L10, L11 and L12. (Lympstone.)

of inflexion of the growth curve was $4 \frac{1}{2}$ times the initial weight, and approximately $10 \cdot 7$ times the body-weight of food had been taken. Growth in weight was most rapid during August, but almost as rapid during September and October (Table 46). Appetite was greatest during late September and early October, when efficiency was highest.

The efficiency of L16 was consistently high, its lowest during growtl being $10 \cdot 2 \mathrm{gm}$. of food per gm. of fish, and the appetite was similarly very great. No other fish took as much as $8.9 \mathrm{gm}$. of food per day, which quantity this fish consumed consistently for a month, from September 16th 
to October 14th, during which period the body-weight was increased by $38.6 \mathrm{gm}$., the greatest increase recorded for any two consecutive fortnightly periods. During this period of rapid growth the highest value for the

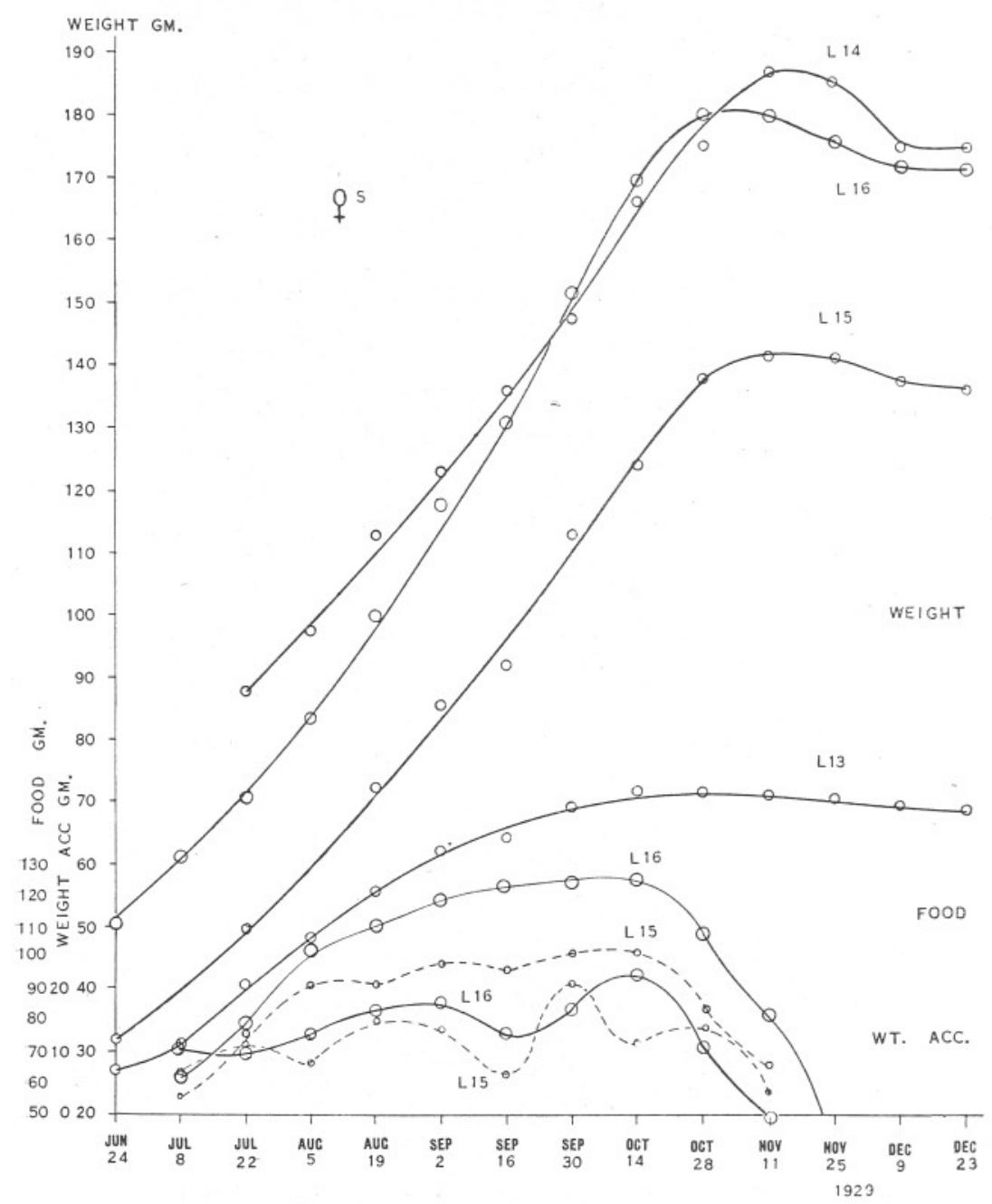

FIG. 15.-Growth curves of weight for the females L13, L14, L15 and L16, together with acceleration curves of food and body-weights for L15 and Li6. (Lympstone).

weight/length ${ }^{3}$ ratio recorded for these experiments was reached (Table 47). The growth curve of weight is shown in Fig. 15.

The growth-rate of the female fish L13 was very slow, an increase in weight of $9.5 \mathrm{gm}$. during July being the greatest for any fortnightly period during the course of the experiment. The efficiency of the fish was 
low, especially after July, and the general condition ceased to improve. It seems probable that inhibition of growth took place during August (Table 48 and Fig. 15).

The female L14 is probably a 3-year old fish, and it is interesting to compare it with L16. For both fishes alike, maximum growth for any

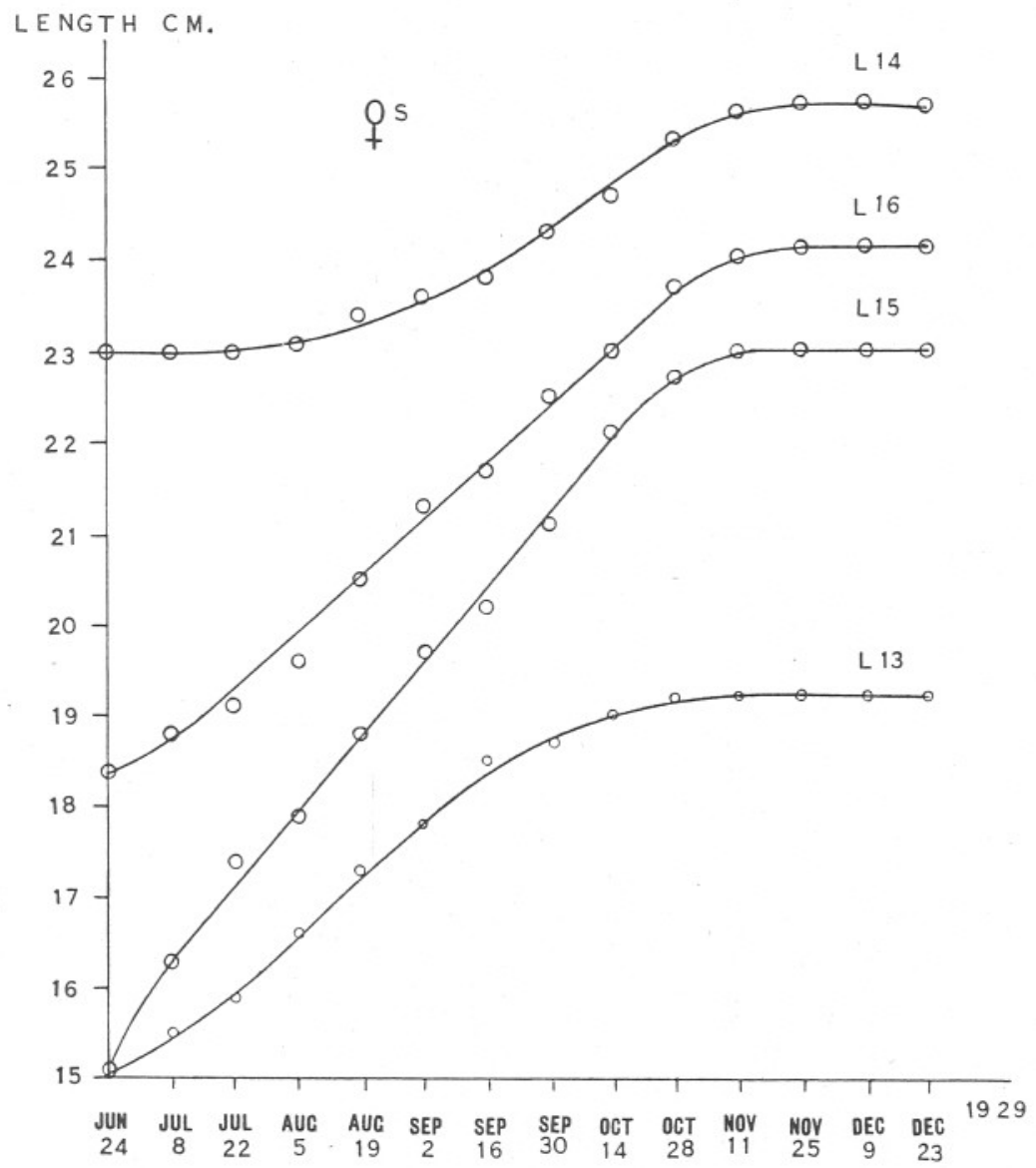

FIG. 16.-Growth curves of length for the females L13, L14, L15 and L16. (Lympstone.)

two consecutive periods occurs during late September and early October, when appetite is greatest, efficiency relatively high and the general condition at its best (Tables 49 and 47). The smaller fish took more food, however, and eventually reached to within $9 \mathrm{gm}$. of the final weight of the larger.

A characteristic feature of growth of the Lympstone fishes is the 
abruptness of a retardation of the process and the loss in weight incurred immediately after growth inhibition, during late November and December. Appetite diminishes very considerably when the maximum temperature approaches $10^{\circ} \mathrm{C}$. and is lost altogether when this temperature sinks below $10^{\circ} \mathrm{C}$. During the growth season there does not appear to be any simple relation between the quantity of food taken per any fortnightly period and the increment of growth in weight for the period. The acceleration curve for food taken is an unbroken one for several consecutive periods, while that of added increments of weight is broken and shows two or three

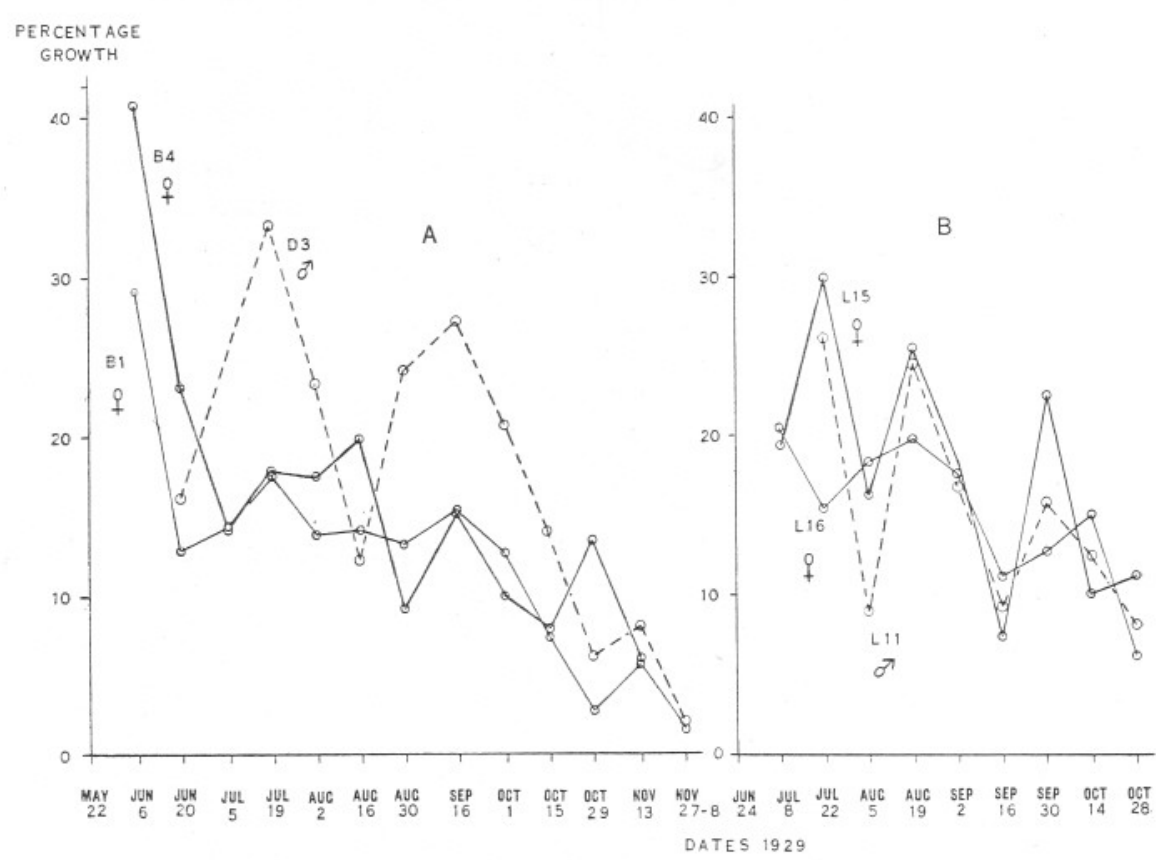

FIG. 17.-Graph showing percentage growth during specified periods for certain maximum fed fish. [A] B1 and B4 ('s) and D3 (O)), Cawsand, [B], L11 and L16 (o's), and L15 (ठ゚), Lympstone.

peaks (Fig. 13-o and Fig. 15-i). The efficiency of any fish appears to vary considerably from period to period.

Growth in length of maximum-fed male and female fishes is shown graphically in Figs. 14 and 16, and it is readily seen that considerable variation occurs in different individuals, especially in the case of males. In the cases of fish of either sex showing any considerable growth, a straight line curve is obtained from July to October. Table 50 (B) and Fig. 17 (B) attempts to show how the percentage growth in weight varies from period to period in both sexes. A coincidence is seen in the fluctuations in percentage growth of the male L11 and the female L15, which 
suggests that a factor which operates to modify the growth-rate from period to period influences both sexes. From August 5th to the close of the experiments, L16 () shows some degree of coincidence also. A corresponding curve of percentage growth is shown for the Cawsand fish (Fig. 17 [A]), the data for which is given in Table 50 (A). Similar periodic fluctuations are seen to obtain, but not altogether independently of sex. It is readily seen by comparison of (A) and (B) sections of Fig. 17

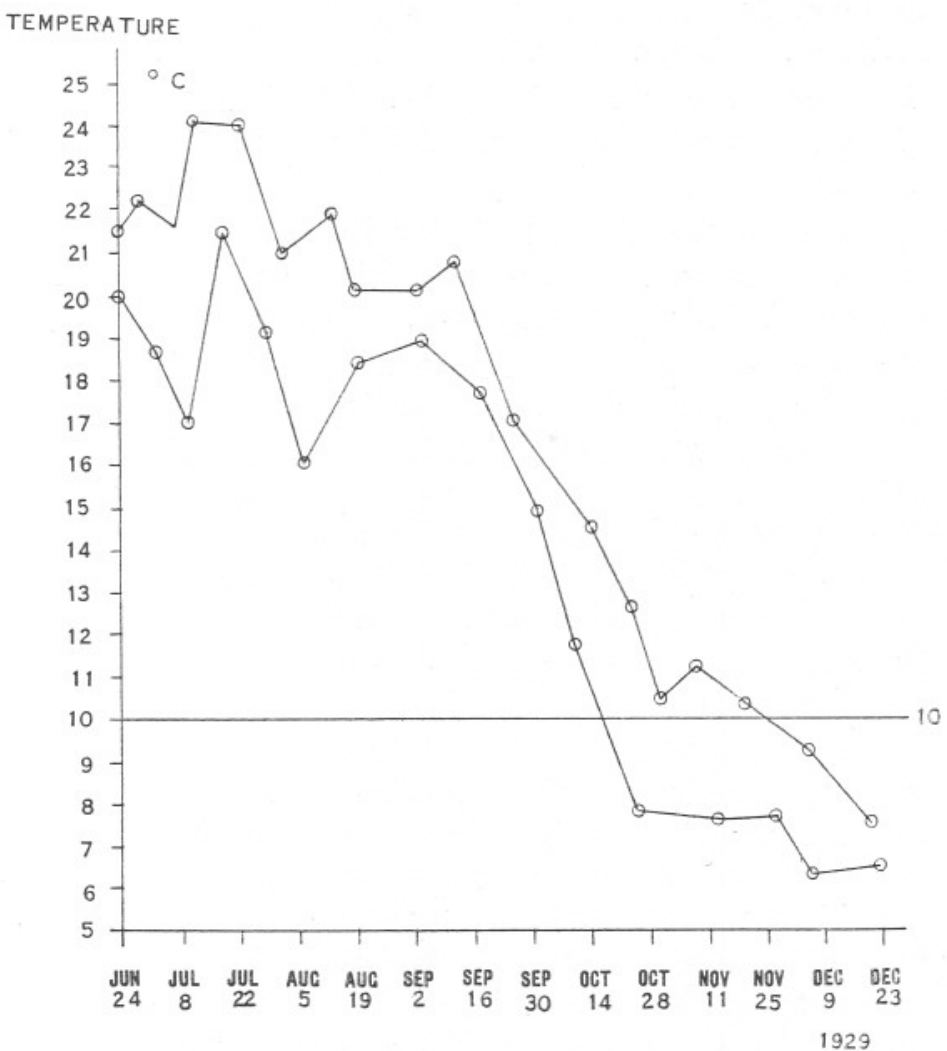

Fig. 18.-Graph of maximum and minimum temperatures at Lympstone (1929).

that the percentage growth is greater in the case of Cawsand males, but smaller in the case of females.

In Fig. 18 is shown a graph of maximum and minimum temperatures of the tank recorded at Lympstone. The temperatures at Lympstone are seen to be consistently much higher from June to September than those obtaining at Cawsand. This fact in part explains the increased appetite and growth of the maximum fish as compared with those at Cawsand and also the slightly higher values of maintenance rations. 


\section{Conclusions Drawn from the Experiments of 1929}

(Lympstone).

(1) Between $0.90 \mathrm{gm}$. and $0.95 \mathrm{gm}$. food per day is necessary in order to maintain constant the body-weight of a $50 \mathrm{-gm}$. male fish (L1).

(2) About 1.4 gm. of food per day is necessary in order to maintain constant the body-weight of a 130-gm. male fish. The maintenance requirements of fish $50 \mathrm{gm}$. to $130 \mathrm{gm}$. in weight range from $0.9 \mathrm{gm}$. to $1.4 \mathrm{gm}$. of food per day.

(3) For female fish $60 \mathrm{gm}$. to $114 \mathrm{gm}$. in weight, from $0.8 \mathrm{gm}$. to $1.5 \mathrm{gm}$. of food per day is required in order to maintain the weight constant.

(4) The ratio of food required per day for purposes of maintenance/ average body-weight of a fish diminishes as the weight of the fish increases, in male and female alike.

(5) Maximum growth for the experiments with male plaice was displayed by L11, which, during a period of 140 days from June 24th, 1929 , increased its length from $16 \cdot 1 \mathrm{~cm}$. to $23 \cdot 1 \mathrm{~cm}$., its weight from $23 \cdot 2 \mathrm{gm}$. to $158 \cdot 6 \mathrm{gm}$. It consumed $926 \mathrm{gm}$. of food, an average of $6 \cdot 6 \mathrm{gm}$. per day, and for the whole period, $6 \cdot 8 \mathrm{gm}$. of food produced $1.0 \mathrm{gm}$. of fish. Maximum growth, appetite and efficiency obtained during the same period, September 16th to October 14th.

(6) The female plaice L15 increased its length from $15 \cdot 1 \mathrm{~cm}$. to $23 \cdot 0 \mathrm{~cm}$. during 126 days from June 24th, its weight from $31.9 \mathrm{gm}$. to 141.1 gm. Maximum growth, appetite and efficiency obtained synchronously during late September. The female L16 increased. its length from $18.4 \mathrm{~cm}$. to $24 \cdot 0 \mathrm{~cm}$. during a period of 140 days, its weight from $50.5 \mathrm{gm}$. to $179 \cdot 3 \mathrm{gm}$. From September 16th to October 14th, a period of 28 days, the fish took roughly $250 \mathrm{gm}$. of food and increased its weight by $38.6 \mathrm{gm}$., 26 per cent of the weight on September 16th.

(7) Growth of both males and females is abruptly retarded when the maximum temperature of the sea-water approaches $10^{\circ} \mathrm{C}$. Growth ceases and loss of weight is incurred when the maximum temperature falls below $10^{\circ} \mathrm{C}$.

\section{GENERAL DISCUSSION OF RESULTS.}

It was seen that during the preliminary experiments of 1928, the average quantity of food required daily for purposes of maintenance by a mean male fish $44 \mathrm{gm}$. in weight is approximately $0 \cdot 6-0 \cdot 7 \mathrm{gm}$. But it was suggested that because the decline of a fish which probably failed to obtain 
food, the value obtained was undoubtedly a low one, and that in all likelihood $0 \cdot 7-0 \cdot 8 \mathrm{gm}$. per day is a more accurate value. Shown as a ratio of the body-weight the value ranges between 0.017 and $0 \cdot 019$, and was suggested as being approximately constant for this fish at $0 \cdot 018$ (Table 1 ).

In Table 51 the average daily food ration of the above mean male fish of the 1928 experiments is shown to November 30th. For a fish of average weight $42.1 \mathrm{gm}$. the daily ration is $0.7 \mathrm{gm}$., or 0.017 of the average weight. Data are also shown in this table which enable us to compare the above result with the results obtained under more refined conditions during 1929 at Cawsand and at Lympstone. The mean A fish of 1928 best compares with C6a (1929) as regards weight, and close conformity is obtained between the observed values for a daily maintenance ration. It is conclusively shown that for a $42 \mathrm{gm}$. male fish, i.e. a fish commencing its third season of growth, $0.7 \mathrm{gm}$. of food or $0 \cdot 017$ of the body-weight, per day is sufficient to maintain the body-weight constant.

For a smaller fish a smaller daily ration is required of course, but the decrease in value of this ration is not directly proportional to the decrease in weight of the fish. Thus, C5a, which is $30 \mathrm{gm}$. in weight, requires $0.6 \mathrm{gm}$. of food per day, or 0.019 of the body-weight (Table 51), while the mean C fish of 1929 , which is much smaller, weighing $17.6 \mathrm{gm}$., requires $0.4 \mathrm{gm}$., or 0.024 of the body-weight of food per day. It is thus rendered clear from comparisons afforded by the results of the Cawsand experiments alone, that the value of the maintenance ratio, i.e. the ratio of food required per day to body-weight, decreases as the weight of the fish increases in the case of males. And this interesting result receives support from the results of the Lympstone experiments with male fish. Thus L1, which weighs $52 \mathrm{gm}$., requires $0.9 \mathrm{gm}$. or 0.017 of the body-weight of food per day, while L2, which weighs $130 \mathrm{gm}$., requires $1 \cdot 4 \mathrm{gm}$. or $0 \cdot 011$ of the body-weight of food daily. It is clear that considerable variation in the value of the maintenance ratio must occur during the third growth season of a plaice. If the initial and final weights are, say, $18 \mathrm{gm}$. and $130 \mathrm{gm}$., the fraction of the body-weight required as daily ration steadily decreases from 0.024 towards $0 \cdot 011$, the actual weight of food per day increasing from $0.4 \mathrm{gm}$. to $1.4 \mathrm{gm}$. In Table 51 several intermediate values are shown, while in Fig. 19 a graph of the variation in maintenance rations with size is shown, as given with the data of the results of Cawsand and Lympstone experiments. As was suggested, the curve is not a straight line one, although the Lympstone data alone gave such a curve. The curve would approximate more closely to a straight line, however, if the temperatures at Lympstone and at Cawsand were identical. The higher temperatures obtaining at Lympstone presumably cause the maintenance requirements to be higher there than at Cawsand.

Comparing the results of the three sets of experiments for the females, it 
is seen that, as in the case of males, the fraction of the body-weight of food required daily for purposes of maintenance decreases as the weight of the fish increases. Thus a Cawsand female fish of $22 \mathrm{gm}$. requires $0 \cdot 4 \mathrm{gm}$. of food per day, a similar fish of $42 \mathrm{gm}$. requires $0.6 \mathrm{gm}$. per day, while a Lympstone fish of $103 \mathrm{gm}$. requires $1 \cdot 3 \mathrm{gm}$. per day ; 0.019, 0.015 and $0 \cdot 013$ of the body-weight respectively (Table 52). The maintenance requirements of several fish of various sizes between $22 \mathrm{gm}$. and $114 \mathrm{gm}$. in weight are also shown in Table 52, and a curve showing the relationship between the daily maintenance ration and size of fish is presented in Fig 19. The curve is open to the same objections as that for the males, but gives

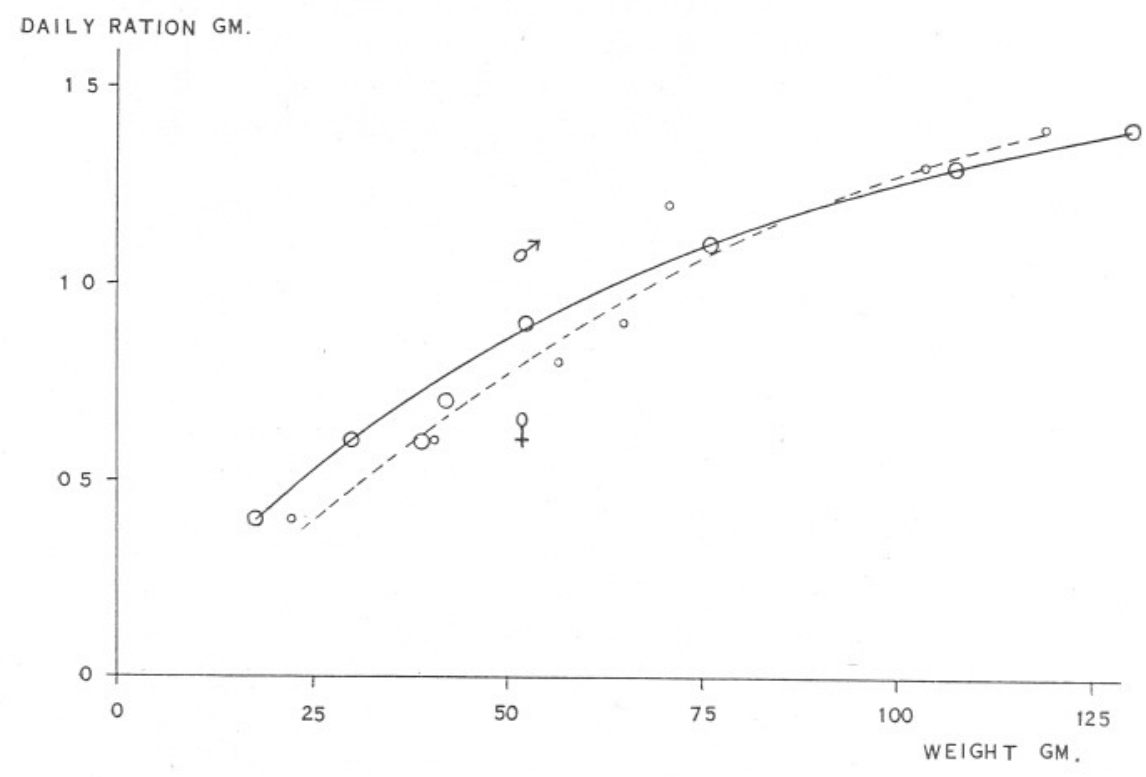

Fig. 19.-Graph showing relationship between daily maintenance ration and size of fish. Based upon Cawsand and Lympstone experiments of 1929.

an approximation of some value. From the evidence obtained, it appears that the maintenance requirements of females are slightly less than those of males, for any fish below $100 \mathrm{gm}$. in weight.

It must be remembered in spite of the generalisations made above, that the maintenance requirements of any fish appear to vary in an irregular manner from one fortnightly period to another. This obtains for Cawsand and Lympstone fish alike. Examples have been given in the general description of the results and merely is it intended here to emphasise the fact that such variations do occur, although it is not possible to account for them.

One fact stands out clearly when one compares the maximum require- 
ments and efficiency of male fish used in the Cawsand experiments of 1928 and 1929, that the maximum requirements of 1928 were much greater, the efficiency much smaller than in the following year (Table 53). The mean male fish of 1928 took $1129 \mathrm{gm}$. of food, while D3, the most rapidly growing male fish of 1929, took only rather more than half this quantity and yet increased its weight more substantially. The values obtained from the refined experiments of 1929 are undoubtedly more accurate than those from the experiments of the previous year, and the efficiency of the fish is much greater than the experiments of 1928 indicated. Over a period of 175 days, D3 increased its weight by $1.0 \mathrm{gm}$. for every $6.5 \mathrm{gm}$. of food it consumed, and took an average of $3 \cdot 3 \mathrm{gm}$. of food per day. At Lympstone, where a higher temperature obtained, growth and appetite were greater, while efficiency was slightly lower. The male fish L11 took $953 \mathrm{gm}$. of food during a period of 154 days, giving an average of $6 \cdot 2 \mathrm{gm}$. per day, and increased its weight by $1 \cdot 0 \mathrm{gm}$. for every $7 \cdot 1 \mathrm{gm}$. of food taken. It can be inferred, therefore, that the efficiency of a fully growing male fish during its third season of growth lies between $6.5 \mathrm{gm}$. and $7 \cdot 1 \mathrm{gm}$. of food per gm. increase in weight. The fish D3 took $9 \cdot 75$ times the average body-weight for the season of food, while L11 took 10.5 times this weight over a slightly shorter period.

Similar results obtain in the case of female fish. The growth rates of males and females in the Cawsand experiments of 1929 are approximately equal as is appetite in the two sexes [cp. D3 ( $\widehat{o})$, Table 53, and B4 and B1 ( $\mathrm{s}$ ), Table 54]. The males show a rather more rapid growth-rate than the females at Lympstone, while at Cawsand in 1928 the reverse was the case. In the females as in the males, growth and appetite were greater at Lympstone than at Cawsand during the season of 1929, and similarly the efficiency was lower. L15 and L16 took $8.1 \mathrm{gm}$. and $8.5 \mathrm{gm}$. of food respectively per gm. increase in weight, while B 4 and B1 took only $7 \cdot 2 \mathrm{gm}$. and $7 \cdot 6 \mathrm{gm}$. for a corresponding increase in weight. The efficiency of the male fish is greater than that of the female at Cawsand and Lympstone alike, and the efficiency of any fish is greater than was indicated by the results of the experiments of 1928 (Tables 53 and 54). The Cawsand fish B4 and B1 took 10 times and 9.5 times the average body-weight for the period respectively of food, the Lympstone fish L15 and L16, 10.3 times and $9 \cdot 4$ times this weight of food respectively, which figures correspond closely to those obtained for the males.

It is seen from Tables 53 and 54 that the growth-rate of different individuals varies considerably. It is difficult to understand why such variations occur. The Cawsand fish were trawled, and it might be argued that the treatment they receive during the process has a baneful effect upon certain individuals. But the Lympstone fish were seined and yet the variations are equally well marked here also. It may be that such 
variations in the growth-rate obtain under truly natural conditions. The fish D3 suffers a retardation of growth during mid-August, and also shows a fall in appetite for food (Fig. 5). There is also a fall in temperature during mid-August (Fig. 11, 1929). The retardation is temporary and is followed by an acceleration at a time when the temperature is rising. The fish D2 shows an almost complete inhibition of growth in weight during mid-August, which is followed by a very great acceleration, while the temperature of the pond is still rising. D4 shows a growth retardation during August and no acceleration follows it. It is not justifiable to assume that because two events occur simultaneously one necessarily acts as a cause to the other, and it may not be the case that growth retardation or inhibition was caused by a fall in temperature of the pond in the above instances, but it is reasonable to assume that the same causes influence different individuals to different degrees and that in the above instances variations in the growth-rate of fish not apparently injured in any way are the outcome of natural causes, rather than the results of accident during the process of trawling or seining. It is thus rendered necessary to ascertain the variations in the growth-rate occurring under truly natural conditions, which task lies outside the scope of this work.

The question of the relationship existing between the quantity of food taken and growth in weight remains unanswered. Over a period of 150 175 days the efficiency of fish showing a markedly rapid growth-rate varies but slightly. But that of different individuals varies very consider. ably. Even in the same fish, good, bad or indifferent, it varies considerably from time to time. In this connexion it is important to note the measure of efficiency for each period for D3 (Table 20), B1 (Table 23), B4 (Table 24), L11 (Table 42), L15 (Table 46), and L16 (Table 47), which may all be taken as " normal " fish showing typical growth curves of length and weight. The variations in weight increments added from pericd to period in these "normal" fish are well beyond reach of the error of the experiments. It is seen in the results of the Cawsand experiments, however, that the acceleration curves for food and weight increments show an approximate degree of correlation (Figs. 5 and 7 ) which suggests that the efficiency of these fish varies fairly closely about a mean. Thus, for B1, a female fish, the efficiency from May 22nd to October 1st, 1929, varies between $5 \cdot 2 \mathrm{gm}$. and $7 \cdot 1 \mathrm{gm}$. of food per gm. increase in weight of the fish. That of the male D3 to October 15 th varies between $4.8 \mathrm{gm}$. and $9 \cdot 8 \mathrm{gm}$. of food per gm. of fish. Such correlation is not found in the Lympstone results (Figs 13 and 15), where appetite is seen to be maintained irrespective of growth acceleration or retardation. Thus, the efficiency of L11 to October 14th varies between $2 \cdot 3 \mathrm{gm}$. and $17 \cdot 8 \mathrm{gm}$. of food per gm. of fish, while for the same period and the same measure of efficiency being understood, the figures for L15 range from $4 \cdot 9$ to $15 \cdot 1$, those for 
L16 from $5 \cdot 7$ to $9 \cdot 4$ (the growth-rate here being uniformly rapid). Thus it is not possible to postulate even an approximately constant index of efficiency for any short period during the growth season.

\section{ACKNOWLEDGMENT.}

I desire to express my sincere thanks to Dr. E. J. Allen, F.R.S., for the assistance he has rendered and the many kindnesses he has shown to me during the course of the investigations. I am also grateful to Dr. E. S. Russell and Mr. T. Edser of the Ministry of Agriculture and Fisheries with whom were discussed the refinements of the experiment and from whom this paper has received useful criticism. My thanks are also tendered to the various members of the Scientific Staff of the Marine Biological Association who have assisted in any way, especially to Mr. G. A. Steven, and to the captain and crew of the Salpa who trawled the fish used in the experiments. Mr. Searle also rendered valuable assistance for which I am grateful. 
TABLE 1.

Data Obtained from the Preliminary Experiment on Maintenance Requirements of Male Plaice.

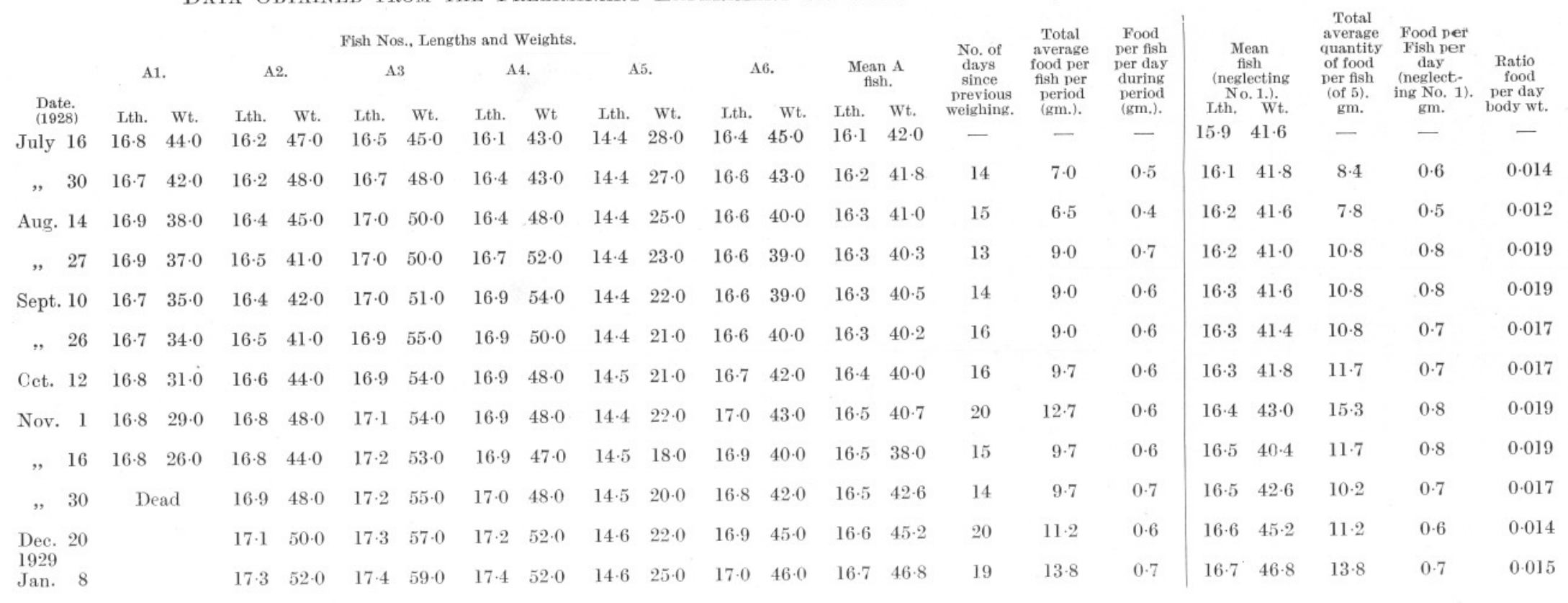




\section{TABLE 2 .}

Data Obtained from the Preliminary Experiment on the M̆aintenance Requirements

of Female Plaice.

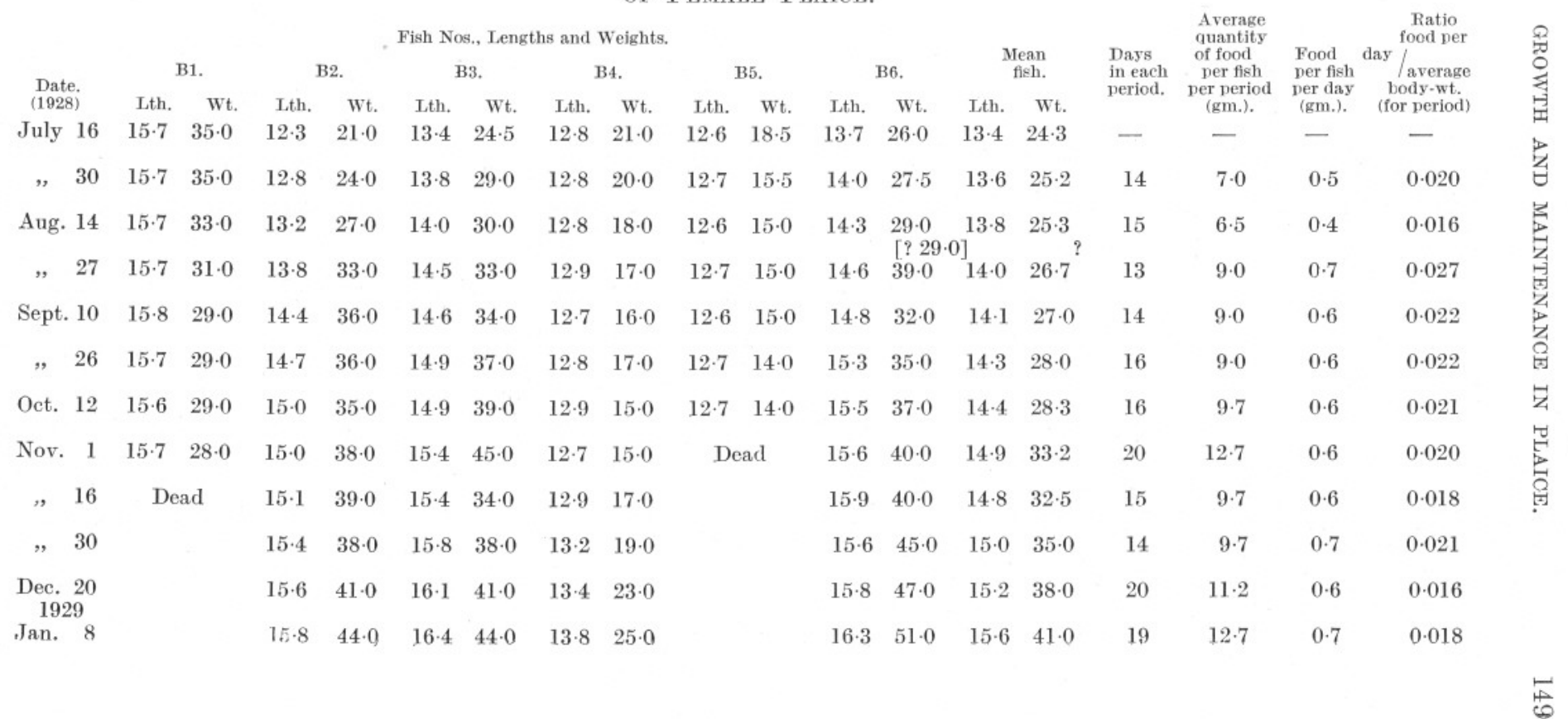


TABLE 3.

Data Obtained from an Experiment on Maximum Feeding and Growth in Male Plaice.

Fish Nos., Lengths and Weights.

C1.

C2.

C3.

C4.

C5.

(1928)

July 16

, 30

Aug. 14

,$\quad 27$

Sept. 10

26

Oct. 12

Nov. 1

,$\quad 16$

30

Dec. 20

1929
Lth. Wt. Lth. Wt. Lth. Wt.

16.8 46.0 15.6 $36 \cdot 0 \quad$ 16.2 3 t. Lth. Wt.

$\begin{array}{llll}16 \cdot 9 & 53 \cdot 0 & 16 \cdot 5 & 39 \cdot 0\end{array}$

$\begin{array}{llll}18 \cdot 1 & 69 \cdot 0 & 16 \cdot 7 & 42 \cdot 0\end{array}$

$\begin{array}{llll}19 \cdot 6 & 96 \cdot 0 & 17 \cdot 2 & 53 \cdot 0\end{array}$

$21.0 \quad 115.0 \quad 18.0 \quad 60.0$

$22.4 \quad 137 \cdot 0 \quad 18.8 \quad 66.0$

$16 \cdot 9 \quad 42 \cdot 0$

$15 \cdot 4 \quad 30 \cdot 0$

$17 \cdot 1 \quad 53 \cdot 0$$$
16 \cdot 2 \quad 43 \cdot 0
$$

$17 \cdot 8 \quad 58 \cdot 0$

$16 \cdot 5 \quad 47$

$19 \cdot 8 \quad 84 \cdot 0$

$-$

Lth. Wt.

$17 \cdot 2 \quad 50 \cdot 0$

$20 \cdot 1 \quad 87 \cdot 0$

$21 \cdot 2101 \cdot 0$

$21 \cdot 7 \quad 116 \cdot 0$

$22 \cdot 6 \quad 128 \cdot 0$

$23 \cdot 5 \quad 151 \cdot 0$

$\begin{array}{llll}18 \cdot 2 & 62 \cdot 0 & 17 \cdot 2 & 45 \cdot 0\end{array}$

$\begin{array}{llll}19 \cdot 0 & 73 \cdot 0 & 17.9 & 52 \cdot 0\end{array}$

$\begin{array}{llllll}16 \cdot 8 & 48 \cdot 0 & 19 \cdot 7 & 80 \cdot 0 & 18 \cdot 1 & 55 \cdot 0\end{array}$

$20 \cdot 3 \quad 86 \cdot 0 \quad 18.5 \quad 62 \cdot 0$

$24 \cdot 1 \quad 158 \cdot 0$

$20.9 \quad 95.0 \quad 18.5 \quad 59.0$

$21 \cdot 1 \quad 100 \cdot 0 \quad 18 \cdot 8 \quad 59 \cdot 0$

$21.4 \quad 101.0 \quad 19.4 \quad 68.0$

$\begin{array}{llll}21.8 & 104 \cdot 0 & 19 \cdot 8 & 76 \cdot 0\end{array}$

$22 \cdot 1 \quad 115 \cdot 0 \quad 20 \cdot 6 \quad 88 \cdot 0$

$22.6 \quad 117.0 \quad 21.0 \quad 95.0$
Mean
C fish.

th. Wt.

0.8
0.8

$\begin{array}{lll}0 & 38.8 \\ & & -1\end{array}$

$6 \cdot 6 \quad 44 \cdot 0$

$17 \cdot 2 \quad 52 \cdot 3$

$18 \cdot 0 \quad 63 \cdot 2$

$18 \cdot 7 \quad 71 \cdot 3$

$19 \cdot 5 \quad 81 \cdot 7$

$19 \cdot 5 \quad 80 \cdot 2$

$20 \cdot 4 \quad 86 \cdot 7$

$20 \cdot 8 \quad 95 \cdot 0$

$21 \cdot 4 \quad 102 \cdot 7$

$22 \cdot 1 \quad 118 \cdot 0$

$22 \cdot 6 \quad 123 \cdot 3$

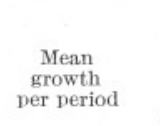

No of Average Mainten- Food Food

weight allowance per period for

$\begin{array}{llll} & \\ \text { previous } & \text { of food } & \text { Der period available } & \text { growth } \\ \text { (=Bdy.: for } & \text { (cumula- }\end{array}$

Wt. $\times$ M growth tive)

Cumula tive

Lth. Wt. (gm.). (gm.). gm.). (to $1 \mathrm{gm}$. .). Lth. Wt.

$\begin{array}{lll}0 \cdot 6 & 8 \cdot 3 \quad 15\end{array}$

$\begin{array}{ll}71 \cdot 7 & 7 \cdot 6\end{array}$

$65 \cdot 0 \quad 7 \cdot 9$

$90 \cdot 0 \quad 12.9$

$00 \cdot 0 \quad 16 \cdot 8$

$90 \cdot 0 \quad 19 \cdot 4$

$97 \cdot 5 \quad 22 \cdot 2$

$127 \cdot 5 \quad 30 \cdot 5$

$97 \cdot 5 \quad 24 \cdot 7$

$97 \cdot 5-29 \cdot 0$

(1)

$133 \cdot 5$

$169 \cdot 0-33 \cdot 6$

$$
\begin{array}{lllllll} 
& & 3 \cdot 5 & 42 \cdot 9 & & & \\
\cline { 2 - 6 } \text { Totals } & 3 \cdot 1 & 43 \cdot 1 & 176 & 1129 \cdot 2 & 227 \cdot 4
\end{array}
$$


TABLE 4 .

Data Obtained from an Experiment on Maximum Feeding and Growth in Female Plaice.

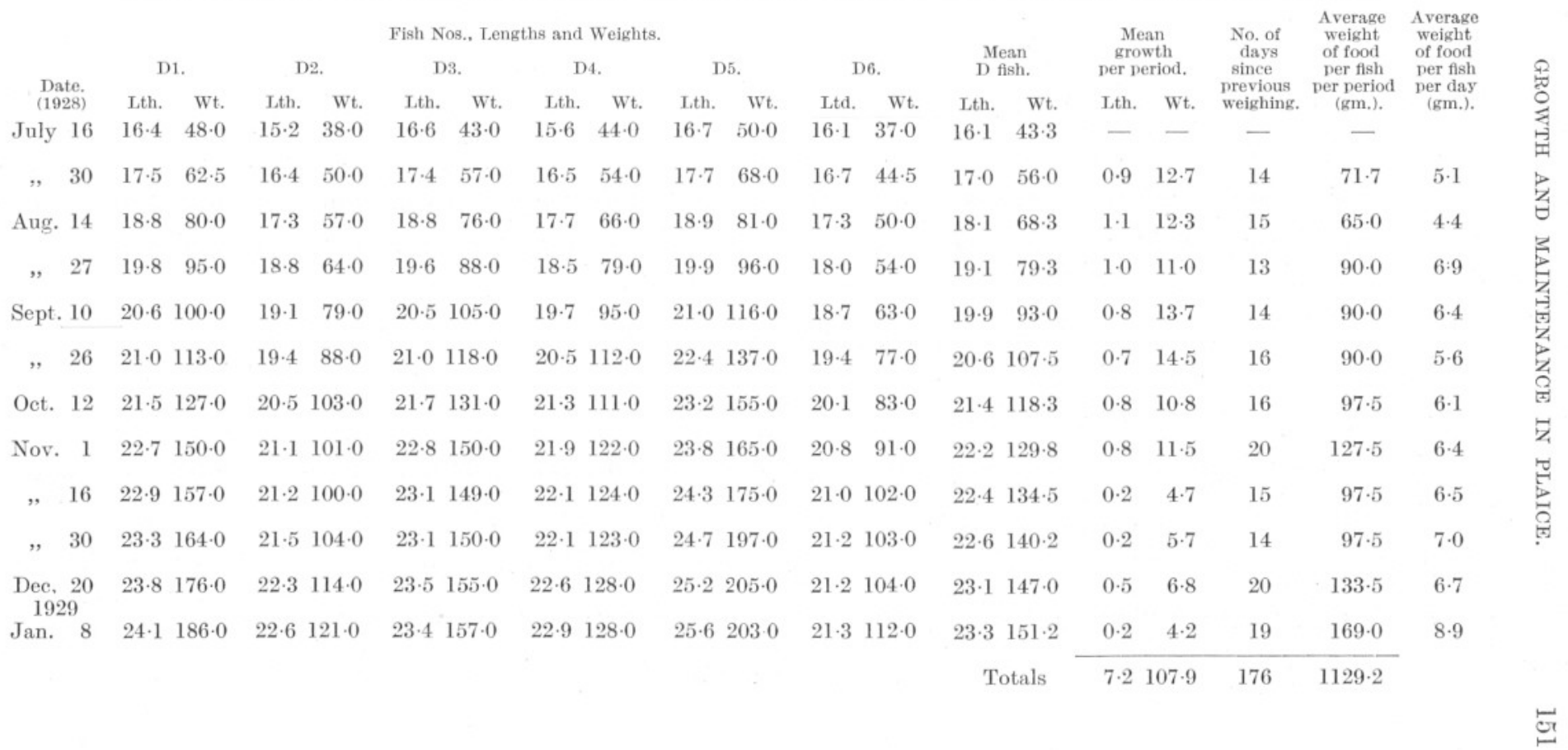


TABLE 5.

Data Obtained from an Experiment on Intermediate Feeding and Growth in Male Plaice.

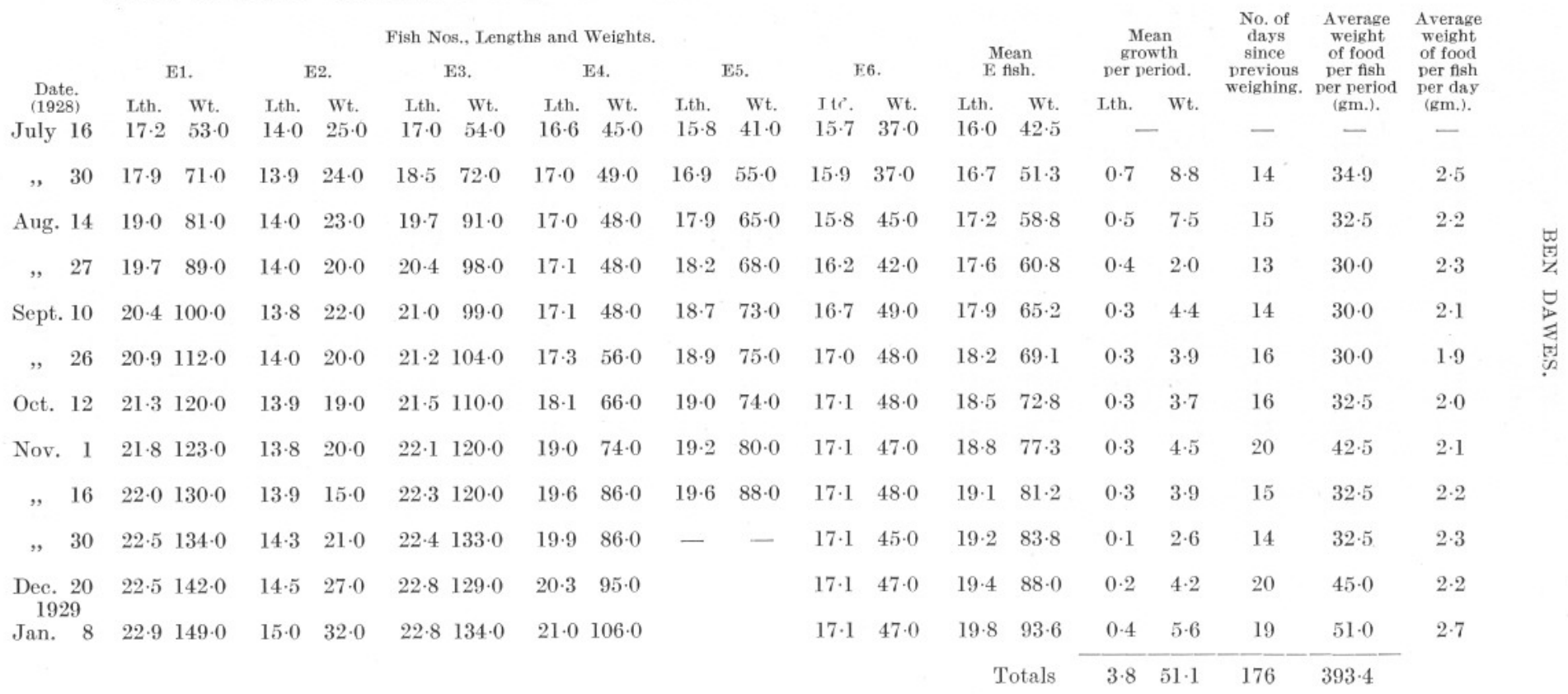


TABLE 6.

Data Obtained from an Experiment on Intermediate Feeding and Growth in Female Plaice.

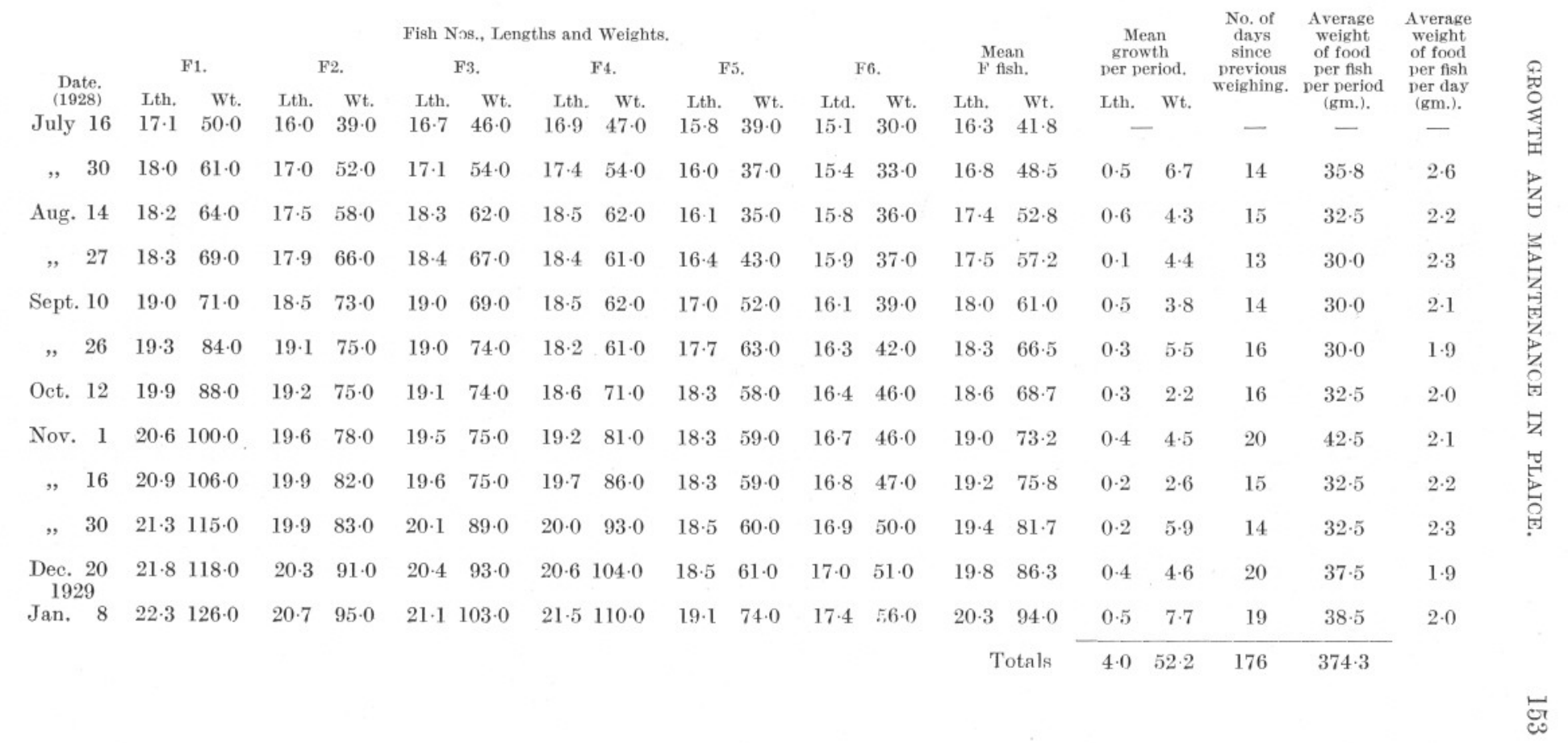




\section{TABLE 7 .}

\section{Data Obtained from the Preliminary Experiments.}

Showing initial and final values for length and weight of the mean fish in each group and also the corresponding increases. Total quantities of food supplied are shown, as is a measure of the efficiency of each mean fish, in terms of gm. of food effecting $1.00 \mathrm{gm}$. increase in fish weight.

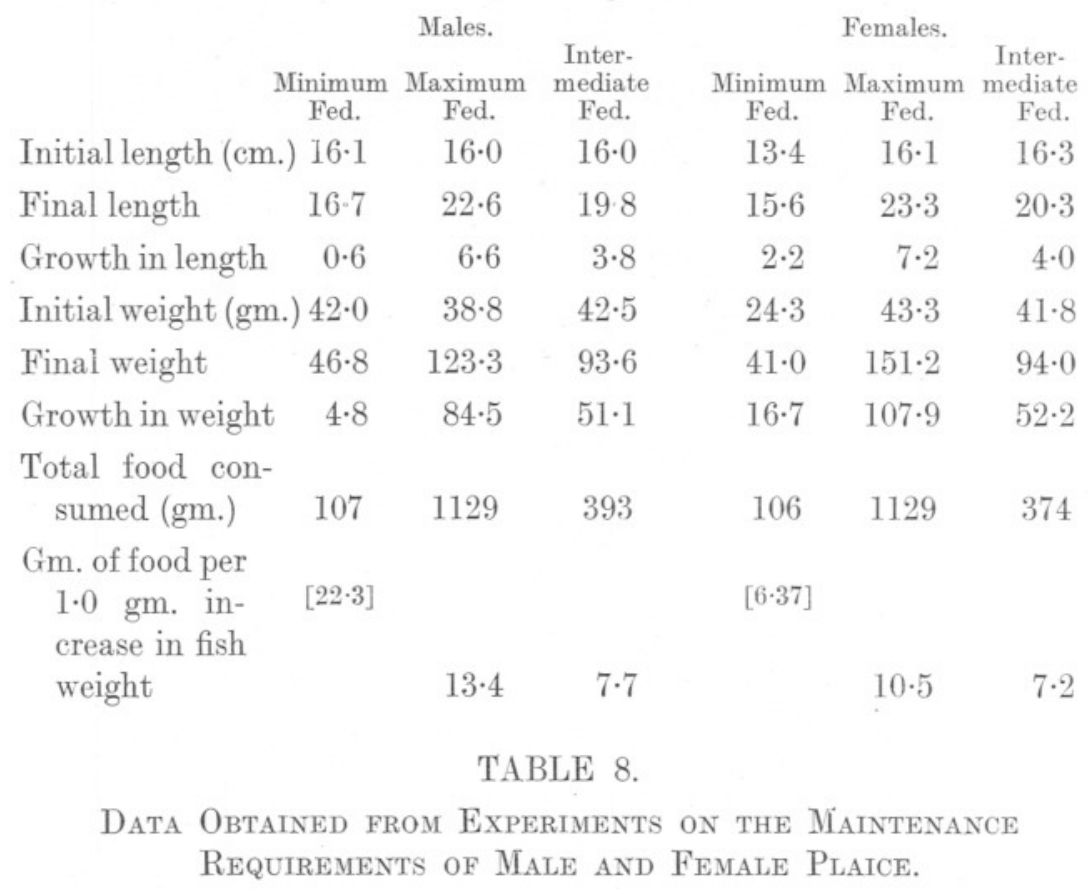

The experiments extended over a period of 44 days, from May 22 nd to July 5th, 1929.

\begin{tabular}{|c|c|c|c|c|c|c|c|c|c|c|}
\hline \multirow{2}{*}{$\begin{array}{l}\text { Fish } \\
\text { No. }\end{array}$} & \multirow{2}{*}{ Sex. } & \multicolumn{2}{|c|}{$\begin{array}{l}\text { Initial } \\
\text { size. }\end{array}$} & \multicolumn{2}{|c|}{$\begin{array}{l}\text { Final } \\
\text { size. }\end{array}$} & \multicolumn{2}{|c|}{$\begin{array}{c}\text { Growth } \\
\text { for period. }\end{array}$} & \multirow{2}{*}{$\begin{array}{l}\text { Total } \\
\text { food } \\
\text { per the } \\
\text { period } \\
\text { (44 days). }\end{array}$} & \multirow{2}{*}{$\begin{array}{c}\text { A verage } \\
\text { weight } \\
\text { of food } \\
\text { per day. } \\
\text { gm. }\end{array}$} & \multirow{2}{*}{$\begin{array}{c}\text { Ratio food per } \\
\text { day./ A verage } \\
\text { body-wt. } \\
\text { (for period) }\end{array}$} \\
\hline & & Lth. & Wt. & Lth. & Wt. & Lth. & Wt. & & & \\
\hline $\mathrm{Cl}$ & $\hat{0}$ & 12.8 & $17 \cdot 5$ & 13.2 & $21 \cdot 5$ & 0.4 & $4 \cdot 0$ & $18 \cdot 6$ & $0 \cdot 42$ & 0.022 \\
\hline $\mathrm{C} 2$ & $\hat{0}$ & $12 \cdot 6$ & $16 \cdot 5$ & $13 \cdot 3$ & $20 \cdot 5$ & 0.7 & $4 \cdot 0$ & $18 \cdot 3$ & $0 \cdot 42$ & 0.023 \\
\hline C3 & $\hat{o}$ & $12 \cdot 7$ & $18 \cdot 0$ & $12 \cdot 9$ & $18 \cdot 0$ & $0 \cdot 2$ & nil & $18 \cdot 6$ & 0.42 & 0.023 \\
\hline $\mathrm{C} 4$ & $\hat{0}$ & $12 \cdot 8$ & $18 \cdot 5$ & $12 \cdot 9$ & $15 \cdot 5$ & $0 \cdot 1$ & $-3 \cdot 0$ & $19 \cdot 0$ & $0 \cdot 43$ & 0.025 \\
\hline C5 & $\hat{o}$ & $12 \cdot 3$ & $15 \cdot 0$ & $12 \cdot 8$ & $18 \cdot 0$ & 0.5 & $3 \cdot 0$ & $18 \cdot 3$ & 0.42 & 0.025 \\
\hline C6 & $\hat{\sigma}$ & $12 \cdot 8$ & 14.5 . & $12 \cdot 9$ & 17.0 & 0.1 & $2 \cdot \tilde{5}$ & $18 \cdot 3$ & 0.42 & 0.027 \\
\hline $\begin{array}{l}\text { Mean } \\
\text { fish }\end{array}$ & $\vec{\sigma}$ & $12 \cdot 7$ & $16 \cdot 7$ & $13 \cdot 0$ & $18 \cdot 4$ & $0 \cdot 3$ & $1 \cdot 7^{5}$ & $18 \cdot 5$ & 0.42 & 0.024 \\
\hline Al & 우 & 13.4 & $20 \cdot 5$ & $13 \cdot 6$ & $22 \cdot 0$ & $0 \cdot 2$ & 1.5 & $18 \cdot 3$ & $0 \cdot 42$ & 0.020 \\
\hline A2 & 우 & $13 \cdot 5$ & $22 \cdot 5$ & $13 \cdot 8$ & $24 \cdot 0$ & $0 \cdot 3$ & 1.5 & $18 \cdot 3$ & $0 \cdot 42$ & 0.018 \\
\hline A3 & 우 & $13 \cdot 5$ & $21 \cdot 0$ & $13 \cdot 8$ & $22 \cdot 0$ & $0 \cdot 3$ & $1 \cdot 0$ & $18 \cdot 6$ & $0 \cdot 42$ & 0.020 \\
\hline A4 & 우 & $13 \cdot 7$ & $21 \cdot 0$ & $13 \cdot 9$ & $22 \cdot 0$ & $0 \cdot 2$ & 1.0 & $18 \cdot 6$ & $0 \cdot 42$ & 0.020 \\
\hline A5 & 우 & $13 \cdot 8$ & $23 \cdot 5$ & $14 \cdot 3$ & $23 \cdot 5$ & 0.5 & nil & $18 \cdot 6$ & 0.42 & 0.018 \\
\hline A 6 & 우 & $13 \cdot 8$ & $24 \cdot 0$ & $13-9$ & $22 \cdot 0$ & $0 \cdot 1$ & $-2 \cdot 0$ & $18 \cdot 9$ & $0 \cdot 43$ & 0.019 \\
\hline $\begin{array}{l}\text { Mean } \\
\text { fish }\end{array}$ & 우 & $13 \cdot 6$ & $22 \cdot 1$ & $13 \cdot 9$ & $22 \cdot 6$ & $0 \cdot 3$ & 0.5 & $18 \cdot 5^{5}$ & $0 \cdot 42$ & 0.019 \\
\hline
\end{tabular}




\section{TABLES 9-11}

Data Obtained from the Experiment on the Maintenance Requirements of Male Fish

TABLE 9: C5A.

\begin{tabular}{|c|c|c|c|c|c|c|c|c|c|c|c|c|}
\hline \multirow[b]{2}{*}{$\begin{array}{c}\text { Date } \\
(1929)\end{array}$} & \multicolumn{2}{|c|}{$\begin{array}{c}\text { Size } \\
\text { of fish. }\end{array}$} & \multicolumn{2}{|c|}{$\begin{array}{l}\text { Growth } \\
\text { per } \\
\text { period. }\end{array}$} & \multirow{3}{*}{$\begin{array}{c}\text { Weight } \\
\text { of food } \\
\text { per } \\
\text { period. } \\
\text { (gm.) }\end{array}$} & \multirow[t]{2}{*}{$\begin{array}{c}\text { No. of } \\
\text { days } \\
\text { in } \\
\text { period. }\end{array}$} & \multirow{3}{*}{$\begin{array}{c}\text { A verage } \\
\text { weight } \\
\text { of food } \\
\text { per day. } \\
\text { (gm.) }\end{array}$} & \multirow{3}{*}{$\begin{array}{c}\text { Total } \\
\text { wt. of } \\
\text { food } \\
\text { to date. } \\
\text { (gm.) } \\
-\end{array}$} & \multirow{3}{*}{$\begin{array}{c}\text { No. of } \\
\text { days } \\
\text { since } \\
\text { commence- } \\
\text { ment of } \\
\text { expt. } \\
\text { _- }\end{array}$} & \multirow{3}{*}{$\begin{array}{c}\text { Average } \\
\text { wt. of } \\
\text { food per } \\
\text { day } \\
\text { to date. } \\
\text { (gm.) } \\
\text { - }\end{array}$} & \multicolumn{2}{|c|}{$\begin{array}{l}\text { Cumulative } \\
\text { growth. }\end{array}$} \\
\hline & Lth. & Wt. & Lth. & Wt. & & & & & & & Lth. & Wt. \\
\hline July 5 & $14 \cdot 4$ & $30 \cdot 5$ & & - & & - & & & & & & \\
\hline,,$\quad 19$ & $14 \cdot 4$ & $26 \cdot 0$ & nil & $-4 \cdot 5$ & $4 \cdot 75$ & 14 & $0 \cdot 34$ & $4 \cdot 75$ & 14 & $0 \cdot 34$ & nil. & $-4 \cdot 5$ \\
\hline Aug. 2 & $14 \cdot 5$ & $25 \cdot 0$ & $0 \cdot 1$ & $-1 \cdot 0$ & $5 \cdot 4$ & 14 & $0 \cdot 39$ & $10 \cdot 15$ & 28 & $0 \cdot 36$ & $0 \cdot 1$ & $-5 \cdot 5$ \\
\hline ,, 16 & $14 \cdot 5$ & $23 \cdot 5$ & nil & $-1 \cdot 5$ & $8 \cdot 25$ & 14 & $0 \cdot 59$ & 18.40 & 42 & 0.44 & $0 \cdot 1$ & $-7 \cdot 0$ \\
\hline ,, 30 & $14 \cdot 5$ & $25 \cdot 5$ & nil & $2 \cdot 0$ & $9 \cdot 00$ & 14 & $0 \cdot 64$ & $27 \cdot 40$ & 56 & $0 \cdot 49$ & $0 \cdot 1$ & $-5 \cdot 0$ \\
\hline Sept. 16 & $14 \cdot 5$ & $27 \cdot 0$ & nil & $1 \cdot 5$ & $11 \cdot 25$ & 17 & 0.66 & 38.65 & 73 & 0.53 & $0 \cdot 1$ & $-3 \cdot 5$ \\
\hline Oct. 1 & $14 \cdot 7$ & $28 \cdot 0$ & $0 \cdot 2$ & 1.0 & $12 \cdot 0$ & 15 & 0.80 & $50 \cdot 65$ & 88 & 0.58 & $0 \cdot 3$ & $-2 \cdot 5$ \\
\hline ,, 15 & $14 \cdot 7$ & $29 \cdot 0$ & nil & 1.0 & $10 \cdot 0$ & 14 & 0.71 & $60 \cdot 65$ & 102 & $0 \cdot 59$ & $0 \cdot 3$ & $-1 \cdot 5$ \\
\hline,$\quad 29$ & $14 \cdot 8$ & $30 \cdot 0$ & $0 \cdot 1$ & $1 \cdot 0$ & $8 \cdot 0$ & 14 & 0.57 & $68 \cdot 65$ & 116 & 0.59 & $0 \cdot 4$ & -0.5 \\
\hline Nov. 13 & $14 \cdot 8$ & $29 \cdot 5$ & nil & -0.5 & $7 \cdot 5$ & 15 & $0 \cdot 50$ & $76 \cdot 15$ & 131 & 0.58 & $0 \cdot 4$ & $-1 \cdot 0$ \\
\hline , $\quad 28$ & $14 \cdot 8$ & $29 \cdot 5$ & nil & nil & $5 \cdot 5$ & 15 & $0 \cdot 4$ & $81 \cdot 65$ & 146 & 0.56 & 0.4 & $-1 \cdot 0$ \\
\hline
\end{tabular}

Table 10: C4a.

\begin{tabular}{|c|c|c|c|c|c|c|c|c|c|c|c|c|}
\hline July 12 & $15 \cdot 6$ & $36 \cdot 0$ & & - & - & - & - & - & - & - & & - \\
\hline & $15 \cdot 6$ & $34 \cdot 5$ & nil & $-1 \cdot 5$ & 1.7 & 7 & $0 \cdot 24$ & 1.7 & 7 & $0 \cdot 24$ & nil & -1.5 \\
\hline Aug. 2 & $15 \cdot 5$ & 33.0 & -0.1 & $-1 \cdot 5$ & $3 \cdot 4$ & 14 & $0 \cdot 24$ & $5 \cdot 1$ & 21 & 0.24 & $-0 \cdot 1$ & $-3 \cdot 0$ \\
\hline , $\quad 16$ & $15 \cdot 6$ & $33 \cdot 5$ & $0 \cdot 1$ & $0 \cdot 5$ & $6 \cdot 0$ & 14 & $0 \cdot 43$ & $11 \cdot 1$ & 35 & 0.32 & nil & $-2 \cdot 5$ \\
\hline 30 & $15 \cdot 7$ & $34 \cdot 0$ & $0 \cdot 1$ & 0.5 & $12 \cdot 0$ & 14 & 0.86 & $23 \cdot 1$ & 49 & $0 \cdot 47$ & $0 \cdot 1$ & $-2 \cdot 0$ \\
\hline Sept. 16 & $15 \cdot 7$ & $35 \cdot 0$ & nil & 1.0 & $12 \cdot 5$ & 17 & $0 \cdot 74$ & $35 \cdot 6$ & 66 & 0.54 & $0 \cdot 1$ & -1.0 \\
\hline Oet. 1 & $15 \cdot 8$ & $38 \cdot 0$ & $0 \cdot 1$ & $3 \cdot 0$ & $12 \cdot 5$ & 15 & 0.83 & $48 \cdot 1$ & 81 & $0 \cdot 60$ & 0.2 & $2 \cdot 0$ \\
\hline 15 & $16 \cdot 0$ & $39 \cdot 0$ & $0 \cdot 2$ & 1.0 & $10 \cdot 0$ & 14 & 0.71 & $58 \cdot 1$ & 95 & $0 \cdot 61$ & 0.4 & $3 \cdot 0$ \\
\hline,,$\quad 29$ & $16 \cdot 2$ & $40 \cdot 0$ & $0 \cdot 2$ & 1.0 & $8 \cdot 5$ & 14 & $0 \cdot 61$ & $66 \cdot 6$ & 109 & $0 \cdot 61$ & $0 \cdot 6$ & $4 \cdot 0$ \\
\hline Nov. 13 & $16 \cdot 2$ & $42 \cdot 0$ & nil & 2.0 & $8 \cdot 2$ & 15 & 0.55 & $74 \cdot 8$ & 124 & $0 \cdot 60$ & $0 \cdot 6$ & $6 \cdot 0$ \\
\hline
\end{tabular}

Table 11: C6A.

\begin{tabular}{|c|c|c|c|c|c|c|c|c|c|c|c|c|}
\hline July 12 & $16 \cdot 3$ & $41 \cdot 5$ & \multicolumn{2}{|c|}{ - } & - & - & - & - & - & - & & \\
\hline,$\quad 19$ & $16 \cdot 4$ & $40 \cdot 0$ & $0 \cdot 1$ & -1.5 & $1 \cdot 8$ & 7 & $0 \cdot 26$ & 1.8 & 7 & $0 \cdot 26$ & 0.1 & $-1 \cdot 5$ \\
\hline Aug. 2 & $16 \cdot 4$ & $38 \cdot 0$ & nil & $-2 \cdot 0$ & $8 \cdot 0$ & 14 & 0.57 & $9 \cdot 8$ & 21 & 0.47 & 0.1 & $-3 \cdot 5$ \\
\hline,$\quad 16$ & $16 \cdot 5$ & $40 \cdot 0$ & $0 \cdot 1$ & $2 \cdot 0$ & $12 \cdot 3$ & 14 & $0 \cdot 88$ & $22 \cdot 1$ & 35 & 0.63 & $0 \cdot 2$ & $-1 \cdot 5$ \\
\hline 30 & $16 \cdot 5$ & $39 \cdot 5$ & nil & -0.5 & $13 \cdot 0$ & 14 & 0.93 & $35 \cdot 1$ & 49 & 0.72 & $0 \cdot 2$ & $-2 \cdot 0$ \\
\hline Sept. 16 & $16 \cdot 6$ & $40 \cdot 5$ & $0 \cdot 1$ & $1 \cdot 0$ & $15 \cdot 0$ & 17 & $0 \cdot 88$ & $50 \cdot 1$ & 66 & $0 \cdot 76$ & $0 \cdot 3$ & $-1 \cdot 0$ \\
\hline Oct. 1 & $16 \cdot 8$ & $41 \cdot 0$ & $0 \cdot 2$ & $0 \cdot 5$ & $12 \cdot 5$ & 15 & $0 \cdot 83$ & $62 \cdot 6$ & 81 & $0 \cdot 77$ & $0 \cdot 5$ & -0.5 \\
\hline,$\quad 15$ & $16 \cdot 8$ & $43 \cdot 0$ & nil & $2 \cdot 0$ & $12 \cdot 0$ & 14 & $0 \cdot 86$ & $74 \cdot 6$ & 95 & $0 \cdot 79$ & 0.5 & 1.5 \\
\hline,$\Longrightarrow 29$ & $16 \cdot 9$ & $44 \cdot 0$ & 0.1 & 1.0 & 8.0 & 14 & 0.57 & $82 \cdot 6$ & 109 & 0.76 & $0 \cdot 6$ & $2 \cdot 5$ \\
\hline Nov. 13 & $17 \cdot 0$ & $45 \cdot 0$ & 0.1 & 1.0 & $8 \cdot 0$ & 15 & $0 \cdot 53$ & $90 \cdot 6$ & 124 & $0 \cdot 73$ & 0.7 & $3 \cdot 5$ \\
\hline,$\quad 28$ & $17 \cdot 0$ & $44 \cdot 5$ & nil & -0.5 & $5 \cdot 5$ & 15 & $0 \cdot 37$ & $96 \cdot 1$ & 139 & 0.69 & $0 \cdot 7$ & $3 \cdot 0$ \\
\hline
\end{tabular}


TABLE 12.

Data Obtained from the Experiments on the Maintenance Requirements of the Male Plaice, C5a, C4a, and C6a.

\begin{tabular}{|c|c|c|c|c|c|c|c|c|c|c|}
\hline & & 30.5 & C5a & 29.5 & $36 \cdot 0$ & $\mathrm{C} 4 \mathrm{a}$ & $42 \cdot 0$ & $41 \cdot 5$ & c6a & $44 \cdot 5$ \\
\hline $\begin{array}{l}\text { Date. } \\
\text { (1929) }\end{array}$ & $\begin{array}{l}\text { No. of } \\
\text { days } \\
\text { in } \\
\text { period. }\end{array}$ & $\begin{array}{c}\text { Increase } \\
\text { in wt. } \\
\text { per } \\
\text { period. } \\
\text { (gm.) }\end{array}$ & $\begin{array}{l}\text { Food per } \\
\text { day/ } \\
\text { /average } \\
\text { body-wt. } \\
\text { (for } \\
\text { period). }\end{array}$ & $\begin{array}{c}\text { Food per } \\
\text { day//mid } \\
\text { body-wt. } \\
\text { (to date). } \ddagger\end{array}$ & $\begin{array}{c}\text { Increase } \\
\text { in wt. } \\
\text { per } \\
\text { period. } \\
\text { (gm.) }\end{array}$ & $\begin{array}{l}\text { Food per } \\
\text { day/ } \\
\text { /average } \\
\text { body-wt. } \\
\text { (for } \\
\text { period). }\end{array}$ & $\begin{array}{l}\text { Food per } \\
\text { day } / \text { mid } \\
\text { body-wt. } \\
\text { (to date). }\end{array}$ & $\begin{array}{c}\text { Increase } \\
\text { in wt. } \\
\text { per } \\
\text { neriod. } \\
\text { (gm.) }\end{array}$ & $\begin{array}{c}\text { Food per } \\
\text { day/ } \\
\text { /average } \\
\text { body-wt. } \\
\text { (for } \\
\text { period). }\end{array}$ & $\begin{array}{c}\begin{array}{c}\text { Food per } \\
\text { day } / \mathrm{mid}\end{array} \\
\text { body-wt. } \\
\text { (to date). }\end{array}$ \\
\hline July $5^{*}$ & - & - & - & - & - & - & - & - & - & - \\
\hline,$\quad 19$ & $14 \dagger$ & $-4 \cdot 5$ & 0.012 & 0.012 & $-1 \cdot 5$ & 0.007 & 0.007 & $-1 \cdot 5$ & 0.006 & 0.006 \\
\hline Aug. 2 & 14 & $-1 \cdot 0$ & 0.015 & 0.013 & $-1 \cdot 5$ & 0.007 & 0.007 & $-2 \cdot 0$ & 0.015 & 0.012 \\
\hline,$\quad 16$ & 14 & -1.5 & 0.024 & 0.016 & 0.5 & 0.013 & 0.009 & $2 \cdot 0$ & 0.023 & 0.015 \\
\hline , 30 & 14 & $2 \cdot 0$ & 0.026 & $0 \cdot 017$ & 0.5 & 0.026 & $0 \cdot 013$ & -0.5 & 0.023 & 0.018 \\
\hline Sept. 16 & 17 & 1.5 & 0.025 & 0.018 & 1.0 & 0.021 & 0.015 & $1 \cdot 0$ & 0.022 & 0.019 \\
\hline Oct. 1 & 15 & $1 \cdot 0$ & 0.029 & 0.020 & $3 \cdot 0$ & 0.023 & 0.016 & 0.5 & 0.020 & $0 \cdot 019$ \\
\hline,,$\quad 15$ & 14 & 1.0 & 0.025 & 0.020 & 1.0 & 0.018 & 0.016 & $2 \cdot 0$ & 0.020 & 0.019 \\
\hline , 29 & 14 & $1 \cdot 0$ & 0.019 & 0.020 & 1.0 & 0.015 & 0.016 & 1.0 & 0.013 & 0.018 \\
\hline Nov. 13 & 15 & -0.5 & 0.017 & 0.019 & $2 \cdot 0$ & 0.013 & 0.015 & 1.0 & 0.012 & 0.017 \\
\hline,$\quad 28$ & 15 & nil & 0.014 & 0.019 & - & - & - & -0.5 & 0.008 & 0.016 \\
\hline
\end{tabular}

TABLES 13-15.

Data Obtained from the Experiment on the Maintenance Requirements of Female Fish.

TABle 13: A4A.

\begin{tabular}{|c|c|c|c|c|c|c|c|c|c|c|c|c|}
\hline \multirow{2}{*}{$\begin{array}{c}\text { Date } \\
\text { (1929) }\end{array}$} & \multicolumn{2}{|c|}{$\begin{array}{c}\text { Size } \\
\text { of fish. }\end{array}$} & \multicolumn{2}{|c|}{$\begin{array}{l}\text { Growth } \\
\text { per } \\
\text { period. }\end{array}$} & \multirow{2}{*}{$\begin{array}{c}\text { Weight } \\
\text { of food } \\
\text { per } \\
\text { period. } \\
\text { (gm.) }\end{array}$} & \multirow{2}{*}{$\begin{array}{c}\text { No. of } \\
\text { days } \\
\text { in } \\
\text { period. }\end{array}$} & \multirow{2}{*}{$\begin{array}{c}\text { A verage } \\
\text { weight } \\
\text { of food } \\
\text { per day. } \\
\text { (gm.) }\end{array}$} & \multirow{2}{*}{$\begin{array}{l}\text { Total } \\
\text { wt. of } \\
\text { food } \\
\text { to date. } \\
\text { (gm.) }\end{array}$} & \multirow{2}{*}{$\begin{array}{l}\text { No. of } \\
\text { days. } \\
\text { since } \\
\text { commence- } \\
\text { ment of } \\
\text { expt. }\end{array}$} & \multirow{2}{*}{$\begin{array}{l}\text { Average. } \\
\text { wt. of } \\
\text { food per } \\
\text { day } \\
\text { to date. } \\
\text { (gm.) }\end{array}$} & \multicolumn{2}{|c|}{$\begin{array}{l}\text { Cumulative } \\
\text { growth. }\end{array}$} \\
\hline & Lth. & Wt. & Lth. & wt. & & & & & & & Lth. & Wt. \\
\hline July & $15 \cdot 8$ & $39 \cdot 0$ & & - & - & - & - & - & - & - & & - \\
\hline,$\quad 19$ & $15 \cdot 8$ & $32 \cdot 0$ & nil & $-7 \cdot 0$ & $5 \cdot 7$ & 14 & 0.40 & $5 \cdot 7$ & 14 & $0 \cdot 40$ & nil & $-7 \cdot 0$ \\
\hline Aug. $\quad 2$ & $15 \cdot 9$ & $33 \cdot 0$ & 0.1 & $1 \cdot 0$ & $9 \cdot 8$ & 14 & 0.70 & $15 \cdot 5$ & 28 & 0.55 & $0 \cdot 1$. & $-6 \cdot 0$ \\
\hline & $16 \cdot 0$ & $34 \cdot 5$ & 0.1 & 1.5 & $10 \cdot 0$ & 14 & 0.71 & $25 \cdot 5$ & 42 & 0.61 & 0.2 . & $-4 \cdot 5$ \\
\hline ,, 30 & $16 \cdot 1$ & 35.0 & 0.1 & 0.5 & $10 \cdot 5$ & 14 & 0.75 & $36 \cdot 0$ & 56 & 0.64 & 0.3 & $-4 \cdot 0$ \\
\hline Sept. 16 & $16 \cdot 2$ & $37 \cdot 0$ & $0 \cdot 1$ & $2 \cdot 0$ & $12 \cdot 5$ & 17 & $0 \cdot 74$ & $48 \cdot 5$ & 73 & $0 \cdot 66$ & $0 \cdot 4$ & $-2 \cdot 0$ \\
\hline Oct. 1 & $16 \cdot 3$ & $38 \cdot 0$ & $0 \cdot 1$ & 1.0 & $12 \cdot 0$ & 15 & $0 \cdot 80$ & $60 \cdot 5$ & 88 & $0 \cdot 69$ & 0.5. & $-1 \cdot 0$ \\
\hline, 15 & $16 \cdot 5$ & 40.0 & 0.2 & $2 \cdot 0$ & 10.5 & 14 & 0.75 & $71 \cdot 0$ & 102 & 0.70 & 0.7 & 1.0 \\
\hline , 29 & $16 \cdot 7$ & $40 \cdot 5$ & 0.2 & 0.5 & 8.0 & 14 & 0.57 & $79 \cdot 0$ & 116 & 0.68 & 0.9 & 1.5 \\
\hline Nov. 13 & $16 \cdot 8$ & $42 \cdot 0$ & $0 \cdot 1$ & 1.5 & $8 \cdot 5$ & 15 & 0.57 & $87 \cdot 5$ & 131 & $0 \cdot 67$ & $1 \cdot 0$ & $3 \cdot 0$ \\
\hline , 27 & $16 \cdot 8$ & $42 \cdot 0$ & nil & nil & $5 \cdot 5$ & 14 & $0 \cdot 39$ & $93 \cdot 0$ & 145 & 0.64 & $1 \cdot 0$ & $3 \cdot 0$ \\
\hline
\end{tabular}


TABLE 14: A6A.

\begin{tabular}{|c|c|c|c|c|c|c|c|c|c|c|c|c|}
\hline \multirow{2}{*}{$\begin{array}{l}\text { Date } \\
\text { (1929) }\end{array}$} & \multicolumn{2}{|c|}{$\begin{array}{c}\text { Size } \\
\text { of fish. }\end{array}$} & \multicolumn{2}{|c|}{$\begin{array}{l}\text { Growth } \\
\text { per } \\
\text { period. }\end{array}$} & \multirow{2}{*}{$\begin{array}{c}\text { Weight } \\
\text { of food } \\
\text { per } \\
\text { period. } \\
\text { (gm.) }\end{array}$} & \multirow[t]{2}{*}{$\begin{array}{c}\text { No. of } \\
\text { days } \\
\text { in } \\
\text { period. }\end{array}$} & \multirow{2}{*}{$\begin{array}{l}\text { Average } \\
\text { weight } \\
\text { of food } \\
\text { per day. } \\
\text { (gm.) }\end{array}$} & \multirow{2}{*}{$\begin{array}{c}\text { Total } \\
\text { wt. of } \\
\text { food } \\
\text { to date. } \\
\text { (gm.) }\end{array}$} & \multirow[t]{2}{*}{$\begin{array}{l}\text { sirce } \\
\text { commence- } \\
\text { ment cf } \\
\text { expt. }\end{array}$} & \multirow{2}{*}{$\begin{array}{c}\text { wt. of } \\
\text { food per } \\
\text { day } \\
\text { to date. } \\
\text { (gm.) }\end{array}$} & \multicolumn{2}{|c|}{$\begin{array}{c}\text { Cumulative } \\
\text { growth. }\end{array}$} \\
\hline & Lth. & Wt. & Lth. & wt. & & & & & & & Lth. & Wt. \\
\hline 5 & $15 \cdot 7$ & $38 \cdot 0$ & & & - & 一 & - & - & - & - & & - \\
\hline 19 & $15 \cdot 8$ & $34 \cdot 5$ & $0 \cdot 1$ & $-3 \cdot 5$ & $5 \cdot 6^{5}$ & 14 & $0 \cdot 40$ & $5 \cdot 6$ & 14 & $0 \cdot 40$ & $0 \cdot 1$ & $-3 \cdot 5$ \\
\hline g. 2 & $15 \cdot 8$ & $36 \cdot 5$ & nil & $2 \cdot 0$ & $8 \cdot 7$ & 14 & $0 \cdot 62$ & $14 \cdot 3$ & 28 & 0.51 & $0 \cdot 1$ & $-1 \cdot 5$ \\
\hline 16 & $15 \cdot 9$ & $37 \cdot 0$ & $0 \cdot 1$ & $0 \cdot 5$ & $9 \cdot 5^{5}$ & 14 & $0 \cdot 68$ & $23 \cdot 9$ & 42 & 0.57 & $0 \cdot 2$ & $-1 \cdot 0$ \\
\hline 30 & $16 \cdot 0$ & $38 \cdot 0$ & $0 \cdot 1$ & 1.0 & $10 \cdot 5$ & 14 & 0.75 & $34 \cdot 4$ & 56 & 0.61 & 0.3 & nil \\
\hline pt. 16 & $16 \cdot 2$ & $37 \cdot 0$ & $0 \cdot 2$ & $-1 \cdot 0$ & $12 \cdot 5$ & 17 & 0.73 & $46 \cdot 9$ & 73 & $0 \cdot 64$ & 0.5 & $-1 \cdot 0$ \\
\hline ct. 1 & $16 \cdot 4$ & $41 \cdot 0$ & $0 \cdot 2$ & $4 \cdot 0$ & $11 \cdot 0$ & 15 & 0.73 & $57 \cdot 9$ & 88 & 0.66 & 0.7 & $3 \cdot 0$ \\
\hline 15 & $16 \cdot 6$ & $42 \cdot 0$ & $0 \cdot 2$ & $1 \cdot 0$ & $10 \cdot 0$ & 14 & $0 \cdot 71$ & $67 \cdot 9$ & 102 & $0 \cdot 67$ & 0.9 & $4 \cdot 0$ \\
\hline 29 & $16 \cdot 7$ & $43 \cdot 5$ & $0 \cdot 1$ & 1.5 & $8 \cdot 0$ & 14 & 0.57 & $75 \cdot 9$ & 116 & 0.65 & 1.0 & $5 \cdot 5$ \\
\hline .13 & 16.9 & $45 \cdot 0$ & 0.2 & 1.5 & 8.0 & 15 & 0.53 & $83 \cdot 9$ & 131 & 0.64 & $1 \cdot 2$ & $7 \cdot 0$ \\
\hline 27 & 16.9 & $46 \cdot 0$ & nil & 1.0 & $5 \cdot 5$ & 14 & $0 \cdot 39$ & $89 \cdot 4$ & 145 & 0.62 & $1 \cdot 2$ & 8.0 \\
\hline
\end{tabular}

TABLE 15: A3A.

\begin{tabular}{|c|c|c|c|c|c|c|c|c|c|c|c|}
\hline July 12 & $17 \cdot 6$ & $55 \cdot 0$ & - & - & - & - & - & 一 & - & & - \\
\hline,$\quad 19$ & $17 \cdot 6$ & $54 \cdot 5$ & nil -0.5 & $3 \cdot 0$ & 7 & $0 \cdot 43$ & $3 \cdot 0$ & 7 & 0.43 & nil & -0.5 \\
\hline Aug. 2 & $17 \cdot 8$ & $54 \cdot 0$ & $0.2-0.5$ & $9 \cdot 8$ & 14 & 0.70 & $12 \cdot 8$ & 21 & 0.61 & $0 \cdot 2$ & $-1 \cdot 0$ \\
\hline,$\quad 16$ & $18 \cdot 0$ & $54 \cdot 5$ & $0.2 \quad 0.5$ & $13 \cdot 5$ & 14 & 0.96 & $26 \cdot 3$ & 35 & 0.75 & 0.4 & -0.5 \\
\hline 30 & $17 \cdot 9$ & $55 \cdot 0$ & $-0 \cdot 1$ & $12 \cdot 0$ & 14 & 0.86 & $38 \cdot 3$ & 49 & 0.78 & $0 \cdot 3$ & nil \\
\hline Sept. 16 & $17 \cdot 8$ & $55 \cdot 0$ & -0.1 & $13 \cdot 5$ & 17 & $0 \cdot 80$ & $51 \cdot 8$ & 66 & $0 \cdot 78$ & $0 \cdot 2$ & nil \\
\hline Oet. 1 & $17 \cdot 8$ & $57 \cdot 5$ & nil & $12 \cdot 0$ & 15 & $0 \cdot 80$ & $63 \cdot 8$ & 81 & $0 \cdot 79$ & $0 \cdot 2$ & $2 \cdot 5$ \\
\hline 15 & $17 \cdot 9$ & $60 \cdot 0$ & $0 \cdot 1$ & $19 \cdot 5$ & 14 & $1 \cdot 39$ & $83 \cdot 3$ & 95 & 0.88 & $0 \cdot 3$ & $5 \cdot 0$ \\
\hline$\Rightarrow \quad 29$ & $17 \cdot 9$ & $58 \cdot 5$ & nil -1.5 & $14 \cdot 5$ & 14 & $1 \cdot 04$ & 97.8 & 109 & 0.90 & $0 \cdot 3$ & $3 \cdot 5$ \\
\hline Nov. 13 & $17 \cdot 9$ & $60 \cdot 0$ & nil $\quad 1.5$ & $10 \cdot 0$ & 15 & $0 \cdot 67$ & $107 \cdot 8$ & 124 & 0.87 & $0 \cdot 3$ & $5 \cdot 0$ \\
\hline , 27 & $17 \cdot 9$ & $58 \cdot 0$ & nil $-2 \cdot 0$ & $5 \cdot 5$ & 14 & $0 \cdot 39$ & $113 \cdot 3$ & 138 & 0.82 & $0 \cdot 3$ & $3 \cdot 0$ \\
\hline
\end{tabular}

TABLE 16.

Data Obtained from the Experiments on the Maintenance Requirements of the Female Platce A4a, A6a, and A3a.

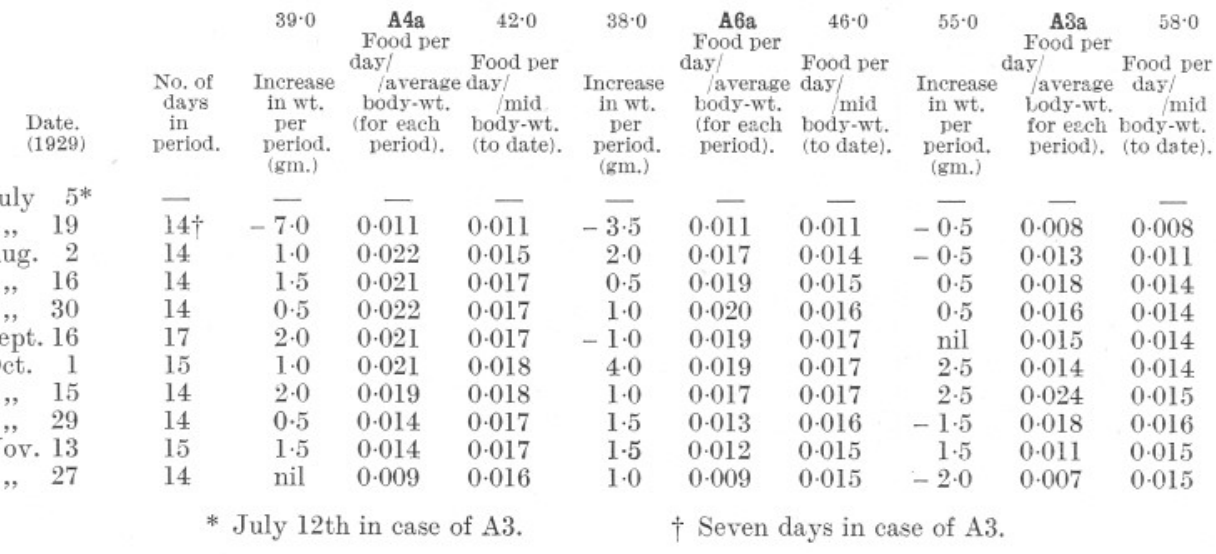


TABLE 17 .

Summarised Data from the Experiments on Maintenance in the Male Platce, C5a, C4a, and C6a, and in the Female Platce, A4a, A6a, and A3a.

\begin{tabular}{|c|c|c|c|c|c|c|c|c|c|c|c|}
\hline \multirow{2}{*}{$\begin{array}{l}\text { Fish } \\
\text { No. }\end{array}$} & \multirow[b]{2}{*}{ Sex. } & \multicolumn{2}{|c|}{$\begin{array}{c}\text { Initial } \\
\text { size. }\end{array}$} & \multicolumn{2}{|c|}{$\begin{array}{l}\text { Final } \\
\text { size. }\end{array}$} & \multicolumn{2}{|c|}{ Growth. } & \multirow{2}{*}{$\begin{array}{c}\text { Period. } \\
\text { (1929). } \\
\text { July 5th }\end{array}$} & \multirow{2}{*}{$\begin{array}{c}\text { Days } \\
\text { in } \\
\text { period. }\end{array}$} & \multirow{2}{*}{$\begin{array}{l}\text { Average } \\
\text { weight } \\
\text { of food } \\
\text { per day } \\
\text { for period. } \\
\text { (gm.). }\end{array}$} & \multirow{2}{*}{$\begin{array}{c}\text { Ratio } \\
\text { Food per } \\
\text { day/ } \\
\text { /averag } \\
\text { body- } \\
\text { weight } \\
\text { for period }\end{array}$} \\
\hline & & Lth. & Wt. & Lth. & Wt. & Lth. & Wt. & & & & \\
\hline C5a & $\hat{0}$ & $14 \cdot 4$ & $30 \cdot 5$ & $14 \cdot 8$ & $29 \cdot 5$ & 0.4 & $-1 \cdot 0$ & $\begin{array}{l}\text { July 5th } \\
\text { to Nov. 28th }\end{array}$ & 146 & $0 \cdot 56$ & $0 \cdot 019$ \\
\hline $\mathrm{C} 4 \mathrm{a}$ & $\tilde{\sigma}$ & $15 \cdot 6$ & $36 \cdot 0$ & $16 \cdot 2$ & $42 \cdot 0$ & $0 \cdot 6$ & $6 \cdot 0$ & $\begin{array}{l}\text { July } 12 \text { th } \\
\text { to Nov. 13th }\end{array}$ & 124 & $0 \cdot 60$ & $0 \cdot 015$ \\
\hline C6a & $\hat{\sigma}$ & $16 \cdot 3$ & $41 \cdot 5$ & $17 \cdot 0$ & $44 \cdot 5$ & 0.7 & $3 \cdot 0$ & $\begin{array}{l}\text { July 12th } \\
\text { to Nov. } 28 \text { th }\end{array}$ & 139 & $0 \cdot 69$ & $0 \cdot 016$ \\
\hline A4a & 우 & $15 \cdot 8$ & $39 \cdot 0$ & $16 \cdot 8$ & $42 \cdot 0$ & $1 \cdot 0$ & $3 \cdot 0$ & $\begin{array}{l}\text { July 5th } \\
\text { to Nov. } 27 \text { th }\end{array}$ & 145 & $0 \cdot 64$ & $0 \cdot 016$ \\
\hline A6a & q & $15 \cdot 7$ & $38 \cdot 0$ & $16 \cdot 9$ & $46 \cdot 0$ & $1 \cdot 2$ & $8 \cdot 0$ & $\begin{array}{l}\text { July 5th } \\
\text { to Nov. 27th }\end{array}$ & 145 & $0 \cdot 62$ & $0 \cdot 015$ \\
\hline A3a & 우 & $17 \cdot 6$ & $55 \cdot 0$ & $17 \cdot 9$ & $58 \cdot 0$ & $0 \cdot 3$ & $3 \cdot 0$ & $\begin{array}{l}\text { July } 12 \text { th } \\
\text { to Nov. } 27 \text { th }\end{array}$ & 138 & $0 \cdot 82$ & 0.015 \\
\hline
\end{tabular}




\section{TABLE 18.}

Showing how the Maintenance Requirements of Male and Female Platce vary with the size of Fish and how these Requirements Diminish During Late November.

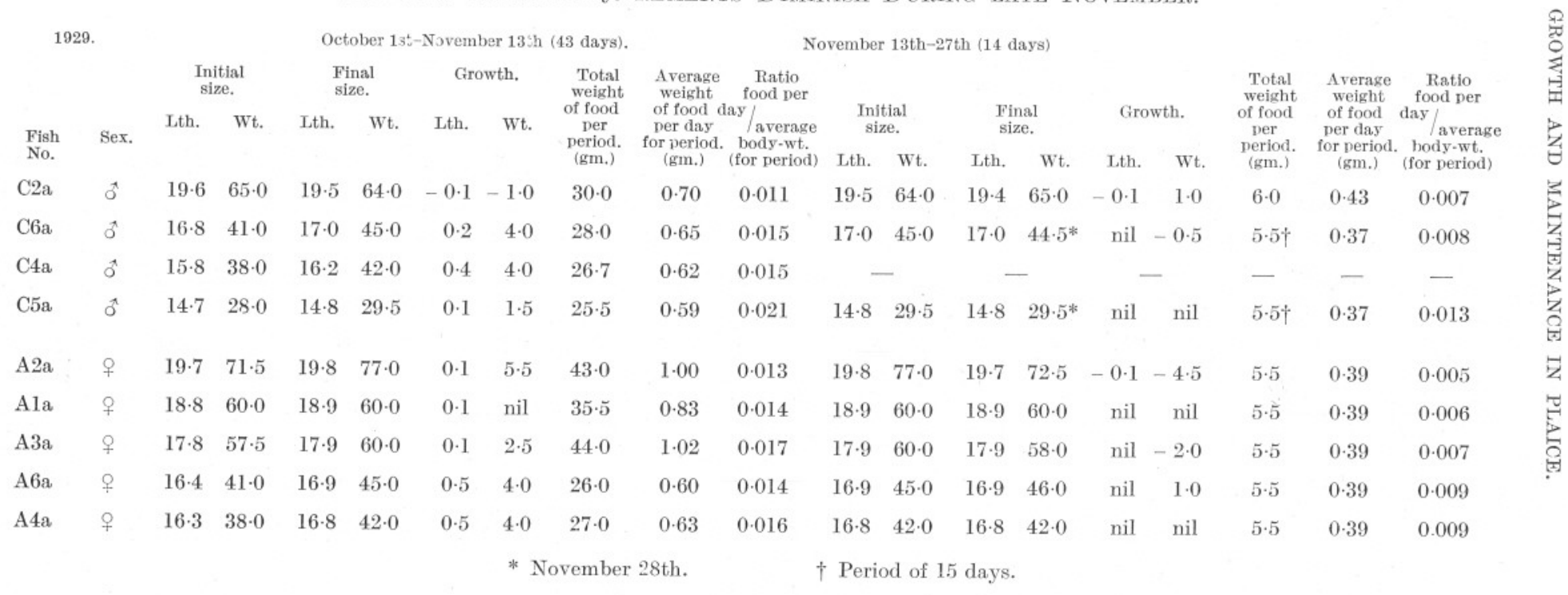


TABLE 19.

Summarised Data Concerning Maximum Requirements and Growth in Miale and Female Plaice.

\begin{tabular}{|c|c|c|c|c|c|c|c|c|c|c|c|}
\hline \multirow{2}{*}{$\begin{array}{l}\text { Fish } \\
\text { No. }\end{array}$} & \multirow[b]{2}{*}{ Sex. } & \multirow[b]{2}{*}{ Period. } & \multirow{2}{*}{$\begin{array}{l}\text { No. of } \\
\text { days in } \\
\text { period. }\end{array}$} & \multicolumn{2}{|c|}{$\begin{array}{c}\text { Initial } \\
\text { size. }\end{array}$} & \multicolumn{2}{|c|}{$\begin{array}{c}\text { Final } \\
\text { size. }\end{array}$} & \multicolumn{2}{|c|}{ Growth. } & \multirow{2}{*}{$\begin{array}{l}\text { Total } \\
\text { food } \\
\text { per the } \\
\text { period. } \\
\text { (gm.). }\end{array}$} & \multirow{2}{*}{$\begin{array}{c}\text { Average } \\
\text { weight } \\
\text { of food } \\
\text { per day } \\
\text { for period } \\
\text { (gm.). }\end{array}$} \\
\hline & & & & Lth. & Wt. & Lth. & Wt. & Lth. & Wt. & & \\
\hline D1 & $\hat{\sigma}$ & May $22-$ Oct. 29 & 160 & $12 \cdot 2$ & $14 \cdot 0$ & $15 \cdot 9$ & $40 \cdot 5$ & $3 \cdot 7$ & $26 \cdot 5$ & 420 & $2 \cdot 6$ \\
\hline D2 & $\hat{\sigma}$ & May 22-Nov. 13 & 175 & $12 \cdot 2$ & $15 \cdot 0$ & $17 \cdot 9$ & $64 \cdot 0$ & $5 \cdot 7$ & $49 \cdot 0$ & 471 & $2 \cdot 7$ \\
\hline D3 & $\hat{o}$ & June 6-Nov. 28 & 175 & $12 \cdot 0$ & $15 \cdot 5$ & $21 \cdot 0$ & $105 \cdot 0$ & $9 \cdot 0$ & $89 \cdot 5$ & 585 & $3 \cdot 3$ \\
\hline D4 & $\hat{o}$ & June 6-Nov. 28 & 175 & $12 \cdot 0$ & $13 \cdot 0$ & $17 \cdot 3$ & $56 \cdot 5$ & $5 \cdot 3$ & 43.5 & 475 & $2 \cdot 7$ \\
\hline D5 & $\hat{o}$ & May 22-Nov. 28 & 190 & $11 \cdot 9$ & $14 \cdot 5$ & $15 \cdot 8$ & $38 \cdot 0$ & $3 \cdot 9$ & $23 \cdot 5$ & 417 & $2 \cdot 2$ \\
\hline D6 & $\hat{\jmath}$ & Miay 22-Nov. 13 & 175 & $12 \cdot 0$ & $17 \cdot 0$ & $14 \cdot 5$ & $24 \cdot 0$ & $2 \cdot 5$ & $7 \cdot 0$ & 361 & $2 \cdot 1$ \\
\hline B1 & q & Viay 22-Nov. 27 & 189 & $13 \cdot 2$ & $24 \cdot 0$ & $21 \cdot 0$ & $105 \cdot 5$ & $7 \cdot 8$ & $81 \cdot 5$ & 618 & $3 \cdot 3$ \\
\hline B2 & 우 & May $22-$ Nov. 27 & 189 & $12 \cdot 7$ & $17 \cdot 0$ & $16 \cdot 9$ & $51 \cdot 0$ & $4 \cdot 2$ & $34 \cdot 0$ & 438 & $2 \cdot 3$ \\
\hline B3 & 우 & June 6-Nov. 27 & 174 & $12 \cdot 6$ & $18 \cdot 0$ & $14 \cdot 5$ & $32 \cdot 0$ & $1 \cdot 9$ & $14 \cdot 0$ & 379 & $2 \cdot 2$ \\
\hline B4 & 우 & May $22-$ Nov. 27 & 189 & $13 \cdot 2$ & $18 \cdot 5$ & $21 \cdot 3$ & $103 \cdot 5$ & $8 \cdot 1$ & $85 \cdot 0$ & 613 & $3 \cdot 3$ \\
\hline B5 & 우 & May 22-Sept. 16 & 117 & $12 \cdot 3$ & $15 \cdot 0$ & $13 \cdot 3$ & $20 \cdot 0$ & $1 \cdot 0$ & $5 \cdot 0$ & 190 & $1 \cdot 6$ \\
\hline B5a & 우 & Sept. 17 -Nov. 27 & 71 & $17 \cdot 9$ & $54 \cdot 0$ & $20 \cdot 1$ & $86 \cdot 0$ & $2 \cdot 2$ & $32 \cdot 0$ & 290 & $4 \cdot 1$ \\
\hline $\mathrm{B} 6$ & 우 & May $22-$ Nov. 27 & 189 & $12 \cdot 0$ & $16 \cdot 0$ & $16 \cdot 7$ & $51 \cdot 0$ & $4 \cdot 7$ & $35 \cdot 0$ & 448 & $2 \cdot 4$ \\
\hline
\end{tabular}


TABLES 20-22.

Maximum Requirements and Growth of Male Plaice.

TABLE 20: D3.

\begin{tabular}{|c|c|c|c|c|c|c|c|c|c|c|c|c|c|}
\hline \multirow{2}{*}{$\begin{array}{l}\text { Date. } \\
(1929)\end{array}$} & \multirow{2}{*}{\multicolumn{3}{|c|}{ Wt. $/$ Lth. $^{3}$}} & & & \multirow{2}{*}{\multicolumn{3}{|c|}{\begin{tabular}{ccc}
\multicolumn{3}{c}{$\begin{array}{c}\text { Gm. of } \\
\text { food }\end{array}$} \\
\multicolumn{3}{c}{ Der } \\
$1.0 \mathrm{gm}$. & \\
Total & increase & No. of \\
food & in & days \\
per & weight in \\
period. of fish. period. \\
(gm.)
\end{tabular}}} & \multirow{2}{*}{$\begin{array}{l}\text { Average } \\
\text { food } \\
\text { per day } \\
\text { during } \\
\text { each } \\
\text { period. } \\
\text { (gm.) }\end{array}$} & \multicolumn{2}{|c|}{$\begin{array}{c}\text { Cumulative } \\
\text { growth. }\end{array}$} & \multirow{2}{*}{$\begin{array}{l}\text { Total } \\
\text { food } \\
\text { to date } \\
\text { from } \\
\text { June } 6 \\
\text { (gm.) }\end{array}$} & \multirow{2}{*}{$\begin{array}{l}\mathrm{Gm} \text {. of } \\
\text { food per } \\
1 \cdot 0 \mathrm{gm} . \\
\text { increase } \\
\text { in wt. } \\
\text { of flsh } \\
\text { to date. }\end{array}$} \\
\hline & & & & Lth. & Wt. & & & & & Lth. & wt. & & \\
\hline June 6 & $12 \cdot 0$ & $15 \cdot 5$ & 0.009 & & & - & - & - & - & - & & - & - \\
\hline,,$\quad 20$ & $12 \cdot 2$ & $18 \cdot 0$ & $0 \cdot 010$ & $0 \cdot 2$ & $2 \cdot 5$ & $22 \cdot 0$ & $8 \cdot 8$ & 14 & $1 \cdot 6$ & $0 \cdot 2$ & $2 \cdot 5$ & 22 & $8 \cdot 8$ \\
\hline July 5 & $13 \cdot 1$ & $22 \cdot 5$ & 0.010 & 0.9 & $4 \cdot 5$ & $26 \cdot 0$ & $5 \cdot 8$ & 15 & 1.7 & $1 \cdot 1$ & $7 \cdot 0$ & 48 & $6 \cdot 9$ \\
\hline,$\quad 19$ & $14 \cdot 1$ & $30 \cdot 0$ & 0.011 & 1.0 & $7 \cdot 5$ & $36 \cdot 0$ & $4 \cdot 8$ & 14 & $2 \cdot 6$ & $2 \cdot 1$ & $14 \cdot 5$ & 84 & $5 \cdot 8$ \\
\hline Aug. 2 & $15 \cdot 0$ & $37 \cdot 0$ & 0.011 & $0 \cdot 9$ & $7 \cdot 0$ & $41 \cdot 4$ & $5 \cdot 9$ & 14 & 3.0 & 3.0 & 21.5 & 125 & $5 \cdot 8$ \\
\hline,,$\quad 16$ & $15 \cdot 9$ & $41 \cdot 5$ & 0.010 & 0.9 & $4 \cdot 5$ & $44 \cdot 2$ & $9 \cdot 8$ & 14 & $3 \cdot 1$ & 3.9 & $26 \cdot 0$ & 170 & $6 \cdot 5$ \\
\hline ,, 30 & $16 \cdot 6$ & $51 \cdot 5$ & 0.011 & 0.7 & $10 \cdot 0$ & $53 \cdot 2$ & $5 \cdot 3$ & 14 & 3.8 & $4 \cdot 6$ & $36 \cdot 0$ & 223 & $6 \cdot 2$ \\
\hline Sept. 16 & $17 \cdot 8$ & $65 \cdot 5$ & 0.012 & $1 \cdot 2$ & $14 \cdot 0$ & $68 \cdot 5$ & $4 \cdot 9$ & 17 & $4 \cdot 0$ & $5 \cdot 8$ & $50 \cdot 0$ & 291 & $5 \cdot 8$ \\
\hline Oct. 1 & $18 \cdot 9$ & $79 \cdot 0$ & 0.012 & $1 \cdot 1$ & $13 \cdot 5$ & $65 \cdot 2$ & $4 \cdot 8$ & 15 & $4 \cdot 3$ & $6 \cdot 9$ & $63 \cdot 5$ & 356 & $5 \cdot 6$ \\
\hline,,$\quad 15$ & $19 \cdot 7$ & $90 \cdot 0$ & 0.012 & 0.8 & 11.0 & 76.5 & $7 \cdot 0$ & 14 & $5 \cdot 5$ & $7 \cdot 7$ & $74 \cdot 5$ & 433 & $5 \cdot 8$ \\
\hline,$\quad 29$ & $20 \cdot 3$ & $95 \cdot 5$ & 0.011 & 0.6 & $5 \cdot 5$ & 63.0 & $11 \cdot 5$ & 14 & $4 \cdot 5$ & $8 \cdot 3$ & $80 \cdot 0$ & 496 & $6 \cdot 2$ \\
\hline Nov. 13 & $20 \cdot 7$ & $103 \cdot 0$ & 0.012 & 0.4 & $7 \cdot 5$ & $50 \cdot 0$ & $6 \cdot 7$ & 15 & $3 \cdot 3$ & $8 \cdot 7$ & $87 \cdot 5$ & 546 & $6 \cdot 2$ \\
\hline , $\quad 28$ & $21 \cdot 0$ & $105 \cdot 0$ & 0.011 & 0.3 & $2 \cdot 0$ & $39 \cdot 0$ & $19 \cdot 5$ & 15 & $2 \cdot 6$ & $9 \cdot 0$ & $89 \cdot 5$ & 585 & $6 \cdot 5$ \\
\hline
\end{tabular}

TABle 21: D2.

\begin{tabular}{|c|c|c|c|c|c|c|c|c|c|c|c|c|c|c|}
\hline May & 22 & $12 \cdot 2$ & $15 \cdot 0$ & 0.008 & - & & - & 一 & - & $\perp$ & \multicolumn{2}{|c|}{ - } & - & - \\
\hline June & 6 & $12 \cdot 6$ & $19 \cdot 5$ & 0.010 & 0.4 & $4 \cdot 5$ & $40 \cdot 0$ & $8 \cdot 9$ & 15 & $2 \cdot 7$ & 0.4 & $4 \cdot 5$ & 40 & 8.9 \\
\hline & 20 & $12 \cdot 9$ & $21 \cdot 0$ & 0.010 & $0 \cdot 3$ & 1.5 & 22.0 & $14 \cdot 7$ & 14 & $1 \cdot 6$ & 0.7 & $6 \cdot 0$ & 62 & $10 \cdot 3$ \\
\hline July & 5 & $13 \cdot 1$ & $22 \cdot 0$ & 0.010 & $0 \cdot 2$ & 1.0 & $26 \cdot 0$ & $26 \cdot 0$ & 15 & $1 \cdot 7$ & 0.9 & $7 \cdot 0$ & 88 & $12 \cdot 6$ \\
\hline & 19 & $13 \cdot 9$ & $27 \cdot 0$ & 0.010 & $0 \cdot 8$ & $5 \cdot 0$ & $33 \cdot 9$ & $6 \cdot 8$ & 14 & $2 \cdot 4$ & $1 \cdot 7$ & $12 \cdot 0$ & 122 & $10 \cdot 2$ \\
\hline Aug. & 2 & $14 \cdot 6$ & $32 \cdot 0$ & 0.010 & $0 \cdot 7$ & $5 \cdot 0$ & $38 \cdot 4$ & $7 \cdot 7$ & 14 & $2 \cdot 7$ & $2 \cdot 4$ & $17 \cdot 0$ & 160 & $9 \cdot 4$ \\
\hline , & 16 & $15 \cdot 3$ & $32 \cdot 5$ & 0.009 & 0.7 & 0.5 & $43 \cdot 1$ & $86 \cdot 2$ & 14 & $3 \cdot 1$ & $3 \cdot 1$ & $17 \cdot 5$ & 203 & $11 \cdot 6$ \\
\hline & 30 & $15 \cdot 8$ & $33 \cdot 0$ & 0.008 & 0.5 & 0.5 & $47 \cdot 0$ & $94 \cdot 0$ & 14 & $3 \cdot 4$ & $3 \cdot 6$ & $18 \cdot 0$ & 250 & $13 \cdot 9$ \\
\hline Sept. & 16 & $16 \cdot 6$ & $49 \cdot 0$ & 0.010 & 0.8 & 16.0 & $58 \cdot 4$ & $3 \cdot 6$ & 17 & $3 \cdot 4$ & $4 \cdot 4$ & $34 \cdot 0$ & 309 & $9 \cdot 1$ \\
\hline Oct. & 1 & $16 \cdot 9$ & $53 \cdot 5$ & 0.011 & $0 \cdot 3$ & $4 \cdot 5$ & $56 \cdot 6$ & $12 \cdot 6$ & 15 & $3 \cdot 8$ & $4 \cdot 7$ & $38 \cdot 5$ & 365 & $9 \cdot 5$ \\
\hline , & 15 & $17 \cdot 4$ & $58 \cdot 0$ & 0.011 & 0.5 & $4 \cdot 5$ & $42 \cdot 5$ & $9 \cdot 4$ & 14 & $3 \cdot 0$ & $5 \cdot 2$ & $43 \cdot 0$ & 408 & $9 \cdot 5$ \\
\hline & 29 & $17 \cdot 6$ & $60 \cdot 5$ & 0.011 & $0 \cdot 2$ & $2 \cdot 5$ & $39 \cdot 0$ & $15 \cdot 6$ & 14 & $2 \cdot 8$ & $5 \cdot 4$ & $45 \cdot 5$ & 447 & $9 \cdot 8$ \\
\hline & 13 & 17 & $64 \cdot 0$ & 0.011 & 0.3 & $3 \cdot 5$ & $\begin{array}{l}24 \cdot 0 \\
2 \cdot 0\end{array}$ & $6 \cdot 9$ & 15 & $1 \cdot 6$ & $5 \cdot 7$ & $49 \cdot 0$ & 471 & $9 \cdot 6$ \\
\hline & & & 63.0 & 0.011 & nil & $-1 \cdot 0$ & $23 \cdot 0-$ & - & 15 & $1 \cdot 5-$ & $5 \cdot 7$ & $48 \cdot 0$ & 494 & $10 \cdot+$ \\
\hline
\end{tabular}

TABLE 22: D4.

\begin{tabular}{|c|c|c|c|c|c|c|c|c|c|c|c|c|c|c|}
\hline June & 6 & $12 \cdot 0$ & $13 \cdot 0$ & 0.008 & & & - & - & - & - & \multicolumn{2}{|c|}{ - } & - & - \\
\hline & 20 & $12 \cdot 1$ & $14 \cdot 0$ & 0.008 & $0 \cdot 1$ & 1.0 & $22 \cdot 0$ & $22 \cdot 0$ & 14 & $1 \cdot 6$ & 0.1 & 1.0 & 22 & $22 \cdot 0$ \\
\hline July & 5 & $12 \cdot 8$ & $19 \cdot 5$ & 0.009 & 0.7 & $5 \cdot 5$ & $26 \cdot 0$ & $4 \cdot 7$ & 15 & $1 \cdot 7$ & 0.8 & 6.5 & 48 & $7 \cdot 4$ \\
\hline & 19 & 13.5 & $24 \cdot 0$ & 0.010 & $0 \cdot 7$ & 4.5 & 33.5 & $7 \cdot 4$ & 14 & $2 \cdot 4$ & 1.5 & $11 \cdot 0$ & 81 & $7 \cdot 4$ \\
\hline Aug. & 2 & $14 \cdot 2$ & $29 \cdot 0$ & 0.010 & $0 \cdot 7$ & $5 \cdot 0$ & 42.5 & 8.5 & 14 & $3 \cdot 0$ & $2 \cdot 2$ & $16 \cdot 0$ & 124 & $7 \cdot 7$ \\
\hline,$\quad 1$ & 16 & $14 \cdot 7$ & $32 \cdot 5$ & 0.010 & 0.5 & $3 \cdot 5$ & $42 \cdot 0$ & $12 \cdot 0$ & 14 & $3 \cdot 0$ & $2 \cdot 7$ & $19 \cdot 5$ & 166 & $8 \cdot 5$ \\
\hline & 30 & $15 \cdot 1$ & $36 \cdot 0$ & 0.010 & 0.4 & $3 \cdot 5$ & $47 \cdot 5$ & 13.5 & 14 & $3 \cdot 4$ & $3 \cdot 1$ & $23 \cdot 0$ & 213 & $9 \cdot 3$ \\
\hline Sept. 1 & 16 & $15 \cdot 6$ & $40 \cdot 0$ & 0.011 & 0.5 & $4 \cdot 0$ & $59 \cdot 9$ & $15 \cdot 0$ & 17 & $4 \cdot 0$ & $3 \cdot 6$ & $27 \cdot 0$ & 273 & $10 \cdot 1$ \\
\hline Oet. & 1 & $16 \cdot 2$ & $47 \cdot 0$ & 0.011 & $0 \cdot 6$ & $7 \cdot 0$ & $51 \cdot 0$ & $7 \cdot 3$ & 15 & $3 \cdot 4$ & $4 \cdot 2$ & $34 \cdot 0$ & 324 & $9 \cdot 5$ \\
\hline , & 15 & $16 \cdot 7$ & $51 \cdot 0$ & 0.011 & 0.5 & $4 \cdot 0$ & $51 \cdot 5$ & $12 \cdot 9$ & 14 & $3 \cdot 7$ & $4 \cdot 7$ & $38 \cdot 0$ & 376 & $9 \cdot 9$ \\
\hline ," & 29 & $17 \cdot 0$ & $55 \cdot 0$ & 0.011 & $0 \cdot 3$ & $4 \cdot 0$ & $46 \cdot 0$ & 11.5 & 14 & $3 \cdot 3$ & $5 \cdot 0$ & $42 \cdot 0$ & 422 & 10.0 \\
\hline Nov. & 13 & $17 \cdot 3$ & $57 \cdot 0$ & 0.011 & $0 \cdot 3$ & $2 \cdot 0$ & $30 \cdot 5$ & $15 \cdot 2$ & 15 & $2 \cdot 0$ & $5 \cdot 3$ & $44 \cdot 0$ & 452 & $10 \cdot 3$ \\
\hline ", & 28 & $17 \cdot 3$ & $56 \cdot 5$ & 0.011 & nil & $-0 \cdot 5$ & $23-$ & - & 15 & $1.5-$ & $5 \cdot 3$ & 43.5 & $475-$ & $10 \cdot 9$ \\
\hline
\end{tabular}

NEW SERIES.-VOL. XVII. No. 1. SEPTEMBER, 1930. 
TABLES 23-27.

Maximum Requirements and Growth of Female Plaice.

TABle 23: B1.

\begin{tabular}{|c|c|c|c|c|c|c|c|c|c|c|c|c|c|}
\hline \multirow{2}{*}{$\begin{array}{l}\text { Date. } \\
(1929)\end{array}$} & \multicolumn{2}{|c|}{$\begin{array}{l}\text { Size } \\
\text { of } \\
\text { fish. }\end{array}$} & \multirow[t]{2}{*}{ Wt. $/$ Lth. $^{3}$} & \multicolumn{2}{|c|}{$\begin{array}{c}\text { Growth } \\
\text { per } \\
\text { period. }\end{array}$} & \multirow[t]{2}{*}{$\begin{array}{c} \\
\begin{array}{c}\text { Total } \\
\text { food } \\
\text { per } \\
\text { period. } \\
\text { (gin.) }\end{array}\end{array}$} & \multirow[t]{2}{*}{$\begin{array}{c}\text { Gm. of } \\
\text { food } \\
\text { per } \\
1.0 \mathrm{gm} . \\
\text { increase } \\
\text { in } \\
\text { weight } \\
\text { of fish. }\end{array}$} & \multirow[t]{2}{*}{$\begin{array}{l}\text { No. of } \\
\text { days } \\
\text { in } \\
\text { reriod. }\end{array}$} & \multirow{2}{*}{$\begin{array}{l}\text { Average } \\
\text { food } \\
\text { per day } \\
\text { during } \\
\text { each } \\
\text { period. } \\
\text { (gm.) }\end{array}$} & \multicolumn{2}{|c|}{$\begin{array}{l}\text { Cumulative } \\
\text { growth. }\end{array}$} & \multirow{2}{*}{$\begin{array}{l}\text { Total } \\
\text { food } \\
\text { to date } \\
\text { from } \\
\text { May 22 } \\
\text { (gm.) }\end{array}$} & \multirow[t]{2}{*}{$\begin{array}{l}\text { Gm. of } \\
\text { food per } \\
1.0 \mathrm{gm} \text {. } \\
\text { increase } \\
\text { in wt. } \\
\text { of fish } \\
\text { to date. }\end{array}$} \\
\hline & Lth. & Wt. & & Lth. & Wt. & & & & & Lth. & wt. & & \\
\hline May 22 & $13 \cdot 2$ & $24 \cdot 0$ & 0.010 & & & - & - & - & - & - & - & - & - \\
\hline June 6 & 14.0 & $31 \cdot 0$ & 0.011 & $0 \cdot 8$ & $7 \cdot 0$ & $40 \cdot 0$ & $5 \cdot 7$ & 15 & $2 \cdot 7$ & 0.8 & $7 \cdot 0$ & 40 & $5 \cdot 7$ \\
\hline & $14 \cdot 7$ & $35 \cdot 0$ & 0.011 & 0.7 & $4 \cdot 0$ & $22 \cdot 0$ & $5 \cdot 5$ & 14 & $1 \cdot 6$ & $1 \cdot 5$ & $11 \cdot 0$ & 62 & $5 \cdot 6$ \\
\hline July 5 & $15 \cdot 4$ & $40 \cdot 0$ & 0.011 & 0.7 & $5 \cdot 0$ & $26 \cdot 0$ & $5 \cdot 2$ & 15 & $1 \cdot 7$ & $2 \cdot 2$ & $16 \cdot 0$ & 88 & $5 \cdot 5$ \\
\hline,$\quad 19$ & $16 \cdot 2$ & $47 \cdot 0$ & 0.011 & 0.8 & $7 \cdot 0$ & $38 \cdot 0$ & $5 \cdot 4$ & 14 & $2 \cdot 7$ & $3 \cdot 0$ & $23 \cdot 0$ & 126 & $5 \cdot 5$ \\
\hline Aug. 2 & $16 \cdot 8$ & $53 \cdot 5$ & 0.011 & $0 \cdot 6$ & $6 \cdot 5$ & $44 \cdot 3$ & $6 \cdot 8$ & 14 & $3 \cdot 2$ & $3 \cdot 6$ & $29 \cdot 5$ & 170 & $5 \cdot 8$ \\
\hline ," 16 & $17 \cdot 5$ & $61 \cdot 0$ & 0.011 & 0.7 & $7 \cdot 5$ & $46 \cdot 2$ & $6 \cdot 2$ & 14 & $3 \cdot 3$ & $4 \cdot 3$ & $37 \cdot 0$ & 216 & $5 \cdot 8$ \\
\hline & $18 \cdot 2$ & $69 \cdot 0$ & 0.011 & $0 \cdot 7$ & $8 \cdot 0$ & $57 \cdot 0$ & $7 \cdot 1$ & 14 & $4 \cdot 1$ & $5 \cdot 0$ & $45 \cdot 0$ & 273 & $6 \cdot 1$ \\
\hline Sept. 16 & $19 \cdot 0$ & $79 \cdot 5$ & 0.012 & 0.8 & $10 \cdot 5$ & $69 \cdot 0$ & $6 \cdot 6$ & 17 & $4 \cdot 1$ & $5 \cdot 8$ & $55 \cdot 5$ & 342 & $6 \cdot 2$ \\
\hline Oct. 1 & $19 \cdot 8$ & $89 \cdot 5$ & 0.012 & 0.8 & $10 \cdot 0$ & $66 \cdot 9$ & $6 \cdot 7$ & 15 & $4 \cdot 5$ & $6 \cdot 6$ & $65 \cdot 5$ & 409 & $6 \cdot 2$ \\
\hline,$\quad 15$ & $20 \cdot 2$ & $96 \cdot 0$ & 0.012 & 0.4 & $6 \cdot 5$ & $63 \cdot 0$ & $9 \cdot 7$ & 14 & $4 \cdot 5$ & $7 \cdot 0$ & $72 \cdot 0$ & 472 & $6 \cdot 6$ \\
\hline & $20 \cdot 5$ & $98 \cdot 5$ & 0.011 & $0 \cdot 3$ & $2 \cdot 5$ & $49 \cdot 0$ & $19 \cdot 6$ & 14 & $3 \cdot 5$ & $7 \cdot 3$ & $74 \cdot 5$ & 521 & $7 \cdot 0$ \\
\hline Nov. 13 & $20 \cdot 8$ & $104 \cdot 0$ & 0.012 & $0 \cdot 3$ & $5 \cdot 5$ & $54 \cdot 0$ & $9 \cdot 8$ & 15 & $3 \cdot 6$ & $7 \cdot 6$ & $80 \cdot 0$ & 575 & $7 \cdot 2$ \\
\hline , 27 & $21 \cdot 0$ & $105 \cdot 5$ & 0.011 & $0 \cdot 2$ & 1.5 & $43-$ & $28 \cdot 7$ & 14 & $3 \cdot 1-$ & $7 \cdot 8$ & $81 \cdot 5$ & 618 & $7 \cdot 6$ \\
\hline Dec. 11 & $21 \cdot 0$ & 105.5 & 0.011 & nil & nil & $28 \cdot 5-$ & $-\quad-$ & 14 & $2 \cdot 0-$ & $7 \cdot 8$ & $81 \cdot 5$ & 646 & - \\
\hline
\end{tabular}

TABle 24: B4.

\begin{tabular}{|c|c|c|c|c|c|c|c|c|c|c|c|c|c|}
\hline May 22 & $13 \cdot 2$ & $18 \cdot 5$ & $0 \cdot 008$ & & & 一 & - & - & - & - & - & - & - \\
\hline June 6 & 13.9 & $26 \cdot 0$ & 0.009 & 0.7 & $7 \cdot 5$ & $40 \cdot 0$ & $5 \cdot 3$ & 15 & $2 \cdot 7$ & 0.7 & $7 \cdot 5$ & 40 & $5 \cdot 3$ \\
\hline,,$\quad 20$ & $14 \cdot 7$ & $32 \cdot 0$ & 0.010 & 0.8 & $6 \cdot 0$ & $22 \cdot 0$ & $3 \cdot 6$ & 14 & $1 \cdot 6$ & 1.5 & $13 \cdot 5$ & 62 & $4 \cdot 6$ \\
\hline July & $15 \cdot 3$ & $36 \cdot 5$ & $0 \cdot 010$ & $0 \cdot 6$ & $4 \cdot 5$ & $26 \cdot 0$ & $5 \cdot 8$ & 15 & $1 \cdot 7$ & $2 \cdot 1$ & $18 \cdot 0$ & 88 & $4 \cdot 9$ \\
\hline 19 & $16 \cdot 1$ & $43 \cdot 0$ & $0 \cdot 010$ & $0 \cdot 8$ & $6 \cdot 5$ & 36.5 & $5 \cdot 6$ & 14 & $2 \cdot 6$ & $2 \cdot 9$ & $24 \cdot 5$ & 124 & $5 \cdot 1$ \\
\hline Aug. 2 & $16 \cdot 9$ & $50 \cdot 5$ & 0.010 & $0 \cdot 8$ & $7 \cdot 5$ & $48 \cdot 7$ & $6 \cdot 5$ & 14 & $3 \cdot 5$ & $3 \cdot 7$ & $32 \cdot 0$ & 173 & $5 \cdot 4$ \\
\hline ,, 16 & $17 \cdot 7$ & $60 \cdot 5$ & $0 \cdot 011$ & $0 \cdot 8$ & $10 \cdot 0$ & $51 \cdot 4$ & $5 \cdot 1$ & 14 & $3 \cdot 7$ & $4 \cdot 5$ & $42 \cdot 0$ & 224 & $5 \cdot 3$ \\
\hline 30 & $18 \cdot 4$ & $66 \cdot 0$ & 0.011 & 0.7 & $5 \cdot 5$ & $54 \cdot 3$ & $9 \cdot 9$ & 14 & $3 \cdot 9$ & $5 \cdot 2$ & $47 \cdot 5$ & 279 & $5 \cdot 9$ \\
\hline Sept. 16 & $19 \cdot 0$ & $76 \cdot 0$ & 0.011 & $0 \cdot 6$ & $10 \cdot 0$ & $65 \cdot 5$ & $6 \cdot 5$ & 17 & $3 \cdot 9$ & $5 \cdot 8$ & $57 \cdot 5$ & 344 & $6 \cdot 0$ \\
\hline Oct. 1 & $19 \cdot 6$ & $83 \cdot 5$ & 0.011 & $0 \cdot 6$ & $7 \cdot 5$ & $55 \cdot 2$ & $7 \cdot 4$ & 15 & $3 \cdot 7$ & $6 \cdot 4$ & $65 \cdot 0$ & 400 & $6 \cdot 2$ \\
\hline 15 & $20 \cdot 2$ & $90 \cdot 0$ & 0.011 & $0 \cdot 6$ & $6 \cdot 5$ & $59 \cdot 0$ & $9 \cdot 1$ & 14 & $4 \cdot 2$ & $7 \cdot 0$ & $71 \cdot 5$ & 459 & $6 \cdot 4$ \\
\hline , $\quad 29$ & $20 \cdot 7$ & $102 \cdot 0$ & 0.011 & $0 \cdot 5$ & $12 \cdot 0$ & $63 \cdot 0$ & $5 \cdot 2$ & 14 & $4 \cdot 5$ & $7 \cdot 5$ & $83 \cdot 5$ & 522 & $6 \cdot 3$ \\
\hline Nov. 13 & $21 \cdot 2$ & $108 \cdot 0$ & $0 \cdot 011$ & 0.5 & $6 \cdot 0$ & $52 \cdot 5$ & $8 \cdot 7$ & 15 & $3 \cdot 5$ & $8 \cdot 0$ & $89 \cdot 5$ & 574 & $6 \cdot 4$ \\
\hline & $21 \cdot 3$ & $103 \cdot 5$ & 0.011 & $0 \cdot 1$ & $-4 \cdot 5$ & $38 \cdot 5-$ & - & 14 & $2 \cdot 7$ & $8 \cdot 1$ & $85 \cdot 0$ & 613 & $7 \cdot 2$ \\
\hline
\end{tabular}

TABle 25: B5A.

\begin{tabular}{|c|c|c|c|c|c|c|c|c|c|c|c|c|c|}
\hline Sept. 17 & $17 \cdot 9$ & 54.0 & 0.009 & & - & - & - & - & - & - & - & - & - \\
\hline Oct. 1 & $18 \cdot 1$ & $59 \cdot 0$ & 0.010 & 0.2 & $5 \cdot 0$ & $42 \cdot 2$ & $8 \cdot 4$ & 14 & $3 \cdot 0$ & $0 \cdot 2$ & $5 \cdot 0$ & 42 & $8 \cdot 4$ \\
\hline 15 & $18 \cdot 9$ & $72 \cdot 5$ & 0.011 & 0.8 & $13 \cdot 5$ & $77 \cdot 5$ & $5 \cdot 7$ & 14 & $5 \cdot 5$ & $1 \cdot 0$ & $18 \cdot 5$ & 120 & 5 \\
\hline , $\quad 29$ & $19 \cdot 7$ & $86 \cdot 0$ & 0.011 & $0 \cdot 8$ & 13.5 & $76 \cdot 5$ & $5 \cdot 7$ & 14 & $5 \cdot 5$ & $1 \cdot 8$ & $32 \cdot 0$ & 196 & 1 \\
\hline Nov. 13 & $20 \cdot 1$ & 89.0 & 0.011 & 0.4 & $3 \cdot 0$ & $57 \cdot 5$ & $19 \cdot 2$ & 15 & $3 \cdot 8$ & $2 \cdot 2$ & $35 \cdot 0$ & 254 & $\cdot 3$ \\
\hline & $20 \cdot 1$ & 86.0 & $0 \cdot 011$ & nil & $-3 \cdot 0$ & $37-$ & - & 14 & $2 \cdot 6$ & $2 \cdot 2$ & $32 \cdot 0$ & $291-$ & \\
\hline
\end{tabular}


Table 26: B2.

\begin{tabular}{|c|c|c|c|c|c|c|c|c|c|c|c|c|c|}
\hline \multirow[b]{2}{*}{$\begin{array}{l}\text { Date. } \\
\text { (1929) }\end{array}$} & \multicolumn{2}{|c|}{$\begin{array}{l}\text { Size } \\
\text { of } \\
\text { fish. }\end{array}$} & \multirow[t]{2}{*}{ Wt. / Lth. ${ }^{3}$} & \multicolumn{2}{|c|}{$\begin{array}{l}\text { Growth } \\
\text { per } \\
\text { period. }\end{array}$} & \multirow{2}{*}{$\begin{array}{c}\text { Total } \\
\text { food } \\
\text { per } \\
\text { period. } \\
\text { (gm.) }\end{array}$} & \multirow[t]{2}{*}{$\begin{array}{c}\text { food } \\
\text { per } \\
1.0 \mathrm{gm} . \\
\text { increase } \\
\text { in } \\
\text { weight } \\
\text { of fish. }\end{array}$} & \multirow[t]{2}{*}{$\begin{array}{c}\text { No. of } \\
\text { days } \\
\text { in } \\
\text { period. }\end{array}$} & \multirow{2}{*}{$\begin{array}{c}\text { A verage } \\
\text { food } \\
\text { per day } \\
\text { during } \\
\text { each } \\
\text { period. } \\
\text { (gm.) }\end{array}$} & \multicolumn{2}{|c|}{$\begin{array}{l}\text { Cumulative } \\
\text { growth. }\end{array}$} & \multirow{2}{*}{\multicolumn{2}{|c|}{$\begin{array}{l}\text { Total 1.0 gm. } \\
\text { food increas } \\
\text { to date in wt. } \\
\text { from of fish } \\
\text { May } 22 \text { to date. } \\
\text { (gm.) }\end{array}$}} \\
\hline & Lth. & Wt. & & Lth. & Wt. & & & & & Lth. & Wt. & & \\
\hline May 22 & $12 \cdot 7$ & $17 \cdot 0$ & 0.008 & & & - & - & - & - & - & - & - & - \\
\hline June 6 & $13 \cdot 3$ & $23 \cdot 0$ & 0.010 & $0 \cdot 6$ & $6 \cdot 0$ & $40 \cdot 0$ & $6 \cdot 7$ & 15 & $2 \cdot 7$ & 0.6 & 6.0 & 40 & $6 \cdot 7$ \\
\hline,$\quad 20$ & $14 \cdot 0$ & $27 \cdot 0$ & 0.010 & 0.7 & $4 \cdot 0$ & $22 \cdot 0$ & $5 \cdot 5$ & 14 & $1 \cdot 6$ & $1 \cdot 3$ & $10 \cdot 0$ & 62 & $6 \cdot 2$ \\
\hline July 5 & $14 \cdot 2$ & $27 \cdot 0$ & 0.009 & $0 \cdot 2$ & nil & 26.0 & - & 15 & $1 \cdot 7$ & 1.5 & $10 \cdot 0$ & 88 & 8.8 \\
\hline,,$\quad 19$ & $14 \cdot 5$ & $28 \cdot 5$ & 0.009 & $0 \cdot 3$ & $1 \cdot 5$ & $23 \cdot 0$ & $15 \cdot 3$ & 14 & $1 \cdot 6$ & 1.8 & $11 \cdot 5$ & 111 & $9 \cdot 7$ \\
\hline Aug. 2 & $14 \cdot 8$ & $30 \cdot 0$ & 0.009 & $0 \cdot 3$ & $1 \cdot 5$ & $30 \cdot 2$ & $20 \cdot 1$ & 14 & $2 \cdot 2$ & $2 \cdot 1$ & $13 \cdot 0$ & 141 & $10 \cdot 8$ \\
\hline , $\quad 16$ & $14 \cdot 9$ & $30 \cdot 5$ & 0.009 & $0 \cdot 1$ & $0 \cdot 5$ & $29 \cdot 7$ & $59 \cdot 4$ & 14 & $2 \cdot 1$ & $2 \cdot 2$ & $13 \cdot 5$ & 171 & $12 \cdot 7$ \\
\hline , 30 & $15 \cdot 2$ & $34 \cdot 0$ & 0.010 & $0 \cdot 3$ & $3 \cdot 5$ & $37 \cdot 8$ & $10 \cdot 8$ & 14 & $2 \cdot 7$ & $2 \cdot 5$ & $17 \cdot 0$ & 209 & $12 \cdot 3$ \\
\hline Sept. 16 & $15 \cdot 5$ & $36 \cdot 5$ & 0.010 & $0 \cdot 3$ & $2 \cdot 5$ & $45 \cdot 6$ & $18 \cdot 2$ & 17 & $2 \cdot 7$ & $2 \cdot 8$ & $19 \cdot 5$ & 254 & $13 \cdot 0$ \\
\hline Oct. 1 & $15 \cdot 7$ & $39 \cdot 5$ & 0.010 & $0 \cdot 2$ & $3 \cdot 0$ & $45 \cdot 3$ & $15 \cdot 1$ & 15 & $3 \cdot 0$ & $3 \cdot 0$ & $22 \cdot 5$ & 300 & $13 \cdot 3$ \\
\hline,,$\quad 15$ & $15 \cdot 8$ & $40 \cdot 0$ & 0.010 & $0 \cdot 1$ & 0.5 & $42 \cdot 0$ & $84 \cdot 0$ & 14 & $3 \cdot 0$ & $3 \cdot 1$ & $23 \cdot 0$ & 342 & $14 \cdot 9$ \\
\hline , $\quad 29$ & $16 \cdot 3$ & $45 \cdot 0$ & & 0.5 & $5 \cdot 0$ & $42 \cdot 5$ & $8 \cdot 5$ & 14 & $3 \cdot 0$ & $3 \cdot 6$ & $28 \cdot 0$ & 384 & $13 \cdot 7$ \\
\hline Nov. 13 & $16 \cdot 7$ & $49 \cdot 5$ & 0.011 & 0.4 & $4 \cdot 5$ & $29 \cdot 5$ & $6 \cdot 6$ & 15 & $2 \cdot 0$ & $4 \cdot 0$ & $32 \cdot 5$ & 414 & $12 \cdot 7$ \\
\hline,$\quad 27$ & $16 \cdot 9$ & $51 \cdot 0$ & 0.011 & $0 \cdot 2$ & 1.5 & $24 \cdot 5$ & $-16 \cdot 3$ & 14 & $1 \cdot 7$ & $4 \cdot 2$ & $34 \cdot 0$ & $438-$ & $12 \cdot 9$ \\
\hline
\end{tabular}

Table 27: B6.

\begin{tabular}{|c|c|c|c|c|c|c|c|c|c|c|c|c|c|c|}
\hline May & 22 & $12 \cdot 0$ & $16 \cdot 0$ & 0.009 & \multicolumn{2}{|c|}{ - } & - & - & - & - & - & - & - & - \\
\hline June & 6 & $12 \cdot 7$ & $23 \cdot 0$ & 0.011 & 0.7 & 7.0 & $40 \cdot 0$ & $5 \cdot 7$ & 15 & $2 \cdot 7$ & 0.7 & 7.0 & 40 & 5.7 \\
\hline & 20 & $13 \cdot 3$ & $25 \cdot 0$ & 0.011 & 0.6 & $2 \cdot 0$ & 22.0 & $11 \cdot 0$ & 14 & $1 \cdot 6$ & $1 \cdot 3$ & $9 \cdot 0$ & 62 & 6.8 \\
\hline July & 5 & $13 \cdot 8$ & $28 \cdot 0$ & 0.011 & 0.5 & 3.0 & $26 \cdot 0$ & $8 \cdot 7$ & 15 & 1.7 & 1.8 & 12.0 & 88 & $7 \cdot 3$ \\
\hline & 19 & $14 \cdot 5$ & $29 \cdot 0$ & 0.010 & 0.7 & $1 \cdot 0$ & $34 \cdot 0$ & $34 \cdot 0$ & 14 & $2 \cdot 4$ & $2 \cdot 5$ & $13 \cdot 0$ & 122 & $9 \cdot 4$ \\
\hline Aug. & 2 & $15 \cdot 1$ & $36 \cdot 0$ & 0.010 & 0.6 & $7 \cdot 0$ & 31.6 & $4 \cdot 5$ & 14 & $2 \cdot 3$ & $3 \cdot 1$ & $20 \cdot 0$ & 154 & $7 \cdot 7$ \\
\hline ," & 16 & $15 \cdot 2$ & $37 \cdot 0$ & 0.011 & $0 \cdot 1$ & $1 \cdot 0$ & $34 \cdot 0$ & $34 \cdot 0$ & 14 & $2 \cdot 4$ & $3 \cdot 2$ & $21 \cdot 0$ & 188 & $9 \cdot 0$ \\
\hline & 30 & $15 \cdot 4$ & $38 \cdot 5$ & 0.011 & 0.2 & 1.5 & $36 \cdot 5$ & $24 \cdot 3$ & 14 & $2 \cdot 6$ & $3 \cdot 4$ & 22.5 & 224 & $10 \cdot 0$ \\
\hline Sept. & .16 & $15 \cdot 7$ & $41 \cdot 5$ & 0.011 & $0 \cdot 3$ & $3 \cdot 0$ & $47 \cdot 1$ & $15 \cdot 7$ & 17 & $2 \cdot 8$ & $3 \cdot 7$ & $25 \cdot 5$ & 271 & $10 \cdot 6$ \\
\hline Oct. & 1 & $15 \cdot 9$ & $44 \cdot 0$ & 0.011 & 0.2 & $2 \cdot 5$ & $44 \cdot 0$ & $17 \cdot 6$ & 15 & $2 \cdot 9$ & 3.9 & $28 \cdot 0$ & 315 & $11 \cdot 2$ \\
\hline , & 15 & $16 \cdot 4$ & $49 \cdot 0$ & 0.011 & 0.5 & $5 \cdot 0$ & $47 \cdot 5$ & $9 \cdot 5$ & 14 & $3 \cdot 4$ & $4 \cdot 4$ & $33 \cdot 0$ & 363 & $11 \cdot 0$ \\
\hline & 29 & 16.5 & $50 \cdot 0$ & 0.011 & $0 \cdot 1$ & $1 \cdot 0$ & $38 \cdot 5$ & $38 \cdot 5$ & 14 & $2 \cdot 7$ & $4 \cdot 5$ & $34 \cdot 0$ & 401 & $11 \cdot 8$ \\
\hline Nov. & 13 & $\begin{array}{l}16.7 \\
16.7\end{array}$ & $\begin{array}{l}53.5 \\
51.0\end{array}$ & 0.011 & 0.2 & $3 \cdot 5$ & $23 \cdot 0$ & $6 \cdot 6$ & 15 & 1.5 & $4 \cdot 7$ & $37 \cdot 5$ & 424 & $11 \cdot 3$ \\
\hline & 27 & $16 \cdot 7$ & 11.0 & 0.011 & nil & $-2 \cdot 5$ & $24-$ & - & 14 & $1 \cdot 7-$ & $4 \cdot 7$ & $35 \cdot 0$ & 448 & $12 \cdot 8$ \\
\hline
\end{tabular}

TABLES 28-31.

Maintenance Requirements of Male Plaice.

TABle 28: Ll.

\begin{tabular}{|c|c|c|c|c|c|c|c|c|c|c|c|c|}
\hline \multirow{2}{*}{$\begin{array}{l}\text { Date. } \\
\text { (1929) }\end{array}$} & \multicolumn{2}{|c|}{$\begin{array}{l}\text { Size } \\
\text { of } \\
\text { flish. }\end{array}$} & \multicolumn{2}{|c|}{$\begin{array}{c}\text { Growth } \\
\text { Der } \\
\text { period. }\end{array}$} & \multirow{2}{*}{$\begin{array}{l}\text { Weight } \\
\text { of food } \\
\text { per } \\
\text { period. } \\
\text { (gm.) }\end{array}$} & \multirow[t]{2}{*}{$\begin{array}{c}\text { No. of } \\
\text { days } \\
\text { in } \\
\text { period. }\end{array}$} & \multirow{2}{*}{$\begin{array}{l}\text { Average } \\
\text { wt. of } \\
\text { food } \\
\text { per day } \\
\text { for each } \\
\text { period. } \\
\text { (gm.) }\end{array}$} & \multirow{2}{*}{$\begin{array}{c}\text { Total } \\
\text { food } \\
\text { to date. } \\
\text { (gm.) }\end{array}$} & \multirow[t]{2}{*}{$\begin{array}{l}\text { No.of } \\
\text { days } \\
\text { since } \\
\text { commence- } \\
\text { ment } \\
\text { of expt. }\end{array}$} & \multirow{2}{*}{$\begin{array}{l}\text { Average } \\
\text { wt. of } \\
\text { food } \\
\text { per day } \\
\text { to date. } \\
\text { (gm.) }\end{array}$} & \multicolumn{2}{|c|}{$\begin{array}{l}\text { Cumulative } \\
\text { growth. }\end{array}$} \\
\hline & Lth. & Wt. & Lth. & Wt. & & & & & & & Lth. & Wt. \\
\hline Aug. 22 & $17 \cdot 0$ & $50 \cdot 3$ & & - & - & - & - & - & - & - & & - \\
\hline Sept. 2 & $17 \cdot 0$ & $49 \cdot 0$ & nil & $-1 \cdot 3$ & $8 \cdot 2$ & 11 & 0.74 & $8 \cdot 2$ & 11 & 0.74 & nil & $-1 \cdot 3$ \\
\hline ," 16 & $17 \cdot 0$ & $47 \cdot 7$ & nil & $-1 \cdot 3$ & $11 \cdot 9$ & 14 & 0.85 & $20 \cdot 1$ & 25 & 0.80 & nil & $-2 \cdot 6$ \\
\hline , 30 & $17 \cdot 0$ & $49 \cdot 9$ & nil & $2 \cdot 2$ & $13 \cdot 3$ & 14 & 0.95 & $33 \cdot 4$ & 39 & 0.86 & nil & -0.4 \\
\hline Oct. 14 & $17 \cdot 2$ & $53 \cdot 1$ & 0.2 & $3 \cdot 2$ & $13 \cdot 4$ & 14 & 0.96 & $46 \cdot 8$ & 53 & 0.88 & $0 \cdot 2$ & $2 \cdot 8$ \\
\hline $\begin{array}{l}, \quad 28 \\
\text {, }\end{array}$ & $17 \cdot 6$ & $52 \cdot 7$ & 0.4 & -0.4 & $12 \cdot 7$ & 14 & 0.91 & $59 \cdot 5$ & 67 & 0.89 & 0.6 & $2 \cdot 4$ \\
\hline Nov. 11 & $17 \cdot 6$ & $54 \cdot 5$ & nil & $1 \cdot 8$ & $13 \cdot 2$ & 14 & 0.94 & $72 \cdot 7$ & 81 & 0.90 & $0 \cdot 6$ & $4 \cdot 2$ \\
\hline ," 25 & $17 \cdot 6$ & $54 \cdot 1$ & nil & -0.4 & 12.6 & 14 & 0.90 & $85 \cdot 3$ & 95 & 0.90 & 0.6 & $3 \cdot 8$ \\
\hline Dec. 9 & $17 \cdot 6$ & $54 \cdot 4$ & nil & 0.3 & $8 \cdot 3$ & 14 & 0.59 & $93 \cdot 6$ & 109 & 0.86 & 0.6 & $4 \cdot 1$ \\
\hline , 23 & $17 \cdot 6$ & $53 \cdot 7$ & nil & -0.7 & 10.5 & 14 & 0.75 & $104 \cdot 1$ & 123 & 0.85 & $0 \cdot 6$ & $3 \cdot 4$ \\
\hline
\end{tabular}


TABle 29: L4a ABove, L4b Below.

\begin{tabular}{|c|c|c|c|c|c|c|c|c|c|c|c|c|}
\hline \multirow{2}{*}{$\begin{array}{l}\text { Date. } \\
\text { (1929) }\end{array}$} & \multicolumn{2}{|c|}{$\begin{array}{l}\text { Size } \\
\text { of } \\
\text { fish. }\end{array}$} & \multicolumn{2}{|c|}{$\begin{array}{l}\text { Growth } \\
\text { per } \\
\text { period. }\end{array}$} & \multirow{2}{*}{$\begin{array}{c}\text { Weight } \\
\text { of food } \\
\text { per } \\
\text { period. } \\
\text { (gm.) }\end{array}$} & \multirow{2}{*}{$\begin{array}{c}\text { No. of } \\
\text { days } \\
\text { in } \\
\text { period. }\end{array}$} & \multirow{2}{*}{$\begin{array}{l}\text { Average } \\
\text { wt. of } \\
\text { food } \\
\text { per day } \\
\text { for each } \\
\text { period. } \\
\text { (gm.) }\end{array}$} & \multirow{2}{*}{$\begin{array}{c}\text { Total } \\
\text { food } \\
\text { to date. } \\
\text { (gm.) }\end{array}$} & \multirow{2}{*}{$\begin{array}{c}\text { No. of } \\
\text { days } \\
\text { since } \\
\text { commence- } \\
\text { ment } \\
\text { of expt. }\end{array}$} & \multirow{2}{*}{$\begin{array}{c}\text { Average } \\
\text { wt. of } \\
\text { food } \\
\text { per day } \\
\text { to date. } \\
\text { (gm.) }\end{array}$} & \multicolumn{2}{|c|}{$\begin{array}{l}\text { Cumulative } \\
\text { growth. }\end{array}$} \\
\hline & Lth. & Wt. & Lth. & Wt. & & & & & & & Lth. & Wt. \\
\hline Aug. 19 & $20 \cdot 8$ & $84 \cdot 7$ & & - & - & - & - & - & - & - & & - \\
\hline Sept. 2 & $20 \cdot 8$ & $83 \cdot 0$ & nil & $-1 \cdot 7$ & $11 \cdot 9$ & 14 & $0 \cdot 85$ & $11 \cdot 9$ & 14 & 0.85 & nil & $-1 \cdot 7$ \\
\hline,,$\quad 16$ & $20 \cdot 8$ & $83 \cdot 7$ & nil & 0.7 & $12 \cdot 3$ & 14 & $0 \cdot 88$ & $24 \cdot 2$ & 28 & $0 \cdot 86$ & nil & $-1 \cdot 0$ \\
\hline Sept. 30 & $20 \cdot 8$ & $75 \cdot 1$ & - & - & - & - & - & - & - & - & & - \\
\hline Oct. 14 & $20 \cdot 9$ & $77 \cdot 7$ & 0.1 & $2 \cdot 6$ & $14 \cdot 0$ & 14 & 1.00 & $14 \cdot 0$ & 14 & $1 \cdot 0$ & 0.1 & $2 \cdot 6$ \\
\hline$\Rightarrow \quad 28$ & $20 \cdot 9$ & $75 \cdot 1$ & nil & $-2 \cdot 6$ & $10 \cdot 6$ & 14 & $0 \cdot 76$ & $24 \cdot 6$ & 28 & $0 \cdot 88$ & $0 \cdot 1$ & nil \\
\hline Nov. 11 & $21 \cdot 0$ & $77 \cdot 2$ & $0 \cdot 1$ & $2 \cdot 1$ & $19 \cdot 6$ & 14 & 1.40 & $44 \cdot 2$ & 42 & 1.05 & $0 \cdot 2$ & $2 \cdot 1$ \\
\hline , $\quad 25$ & $1 \cdot 0$ & $76 \cdot 9$ & nil & $-0 \cdot 3$ & $18 \cdot 2$ & 14 & $1 \cdot 30$ & $62 \cdot 4$ & 56 & $1 \cdot 11$ & 0.2 & 1.8 \\
\hline Dec. 9 & 1.0 & $77 \cdot 2$ & nil & $0 \cdot 3$ & $11 \cdot 9$ & 14 & 0.85 & $74 \cdot 3$ & 70 & 1.06 & $0 \cdot 2$ & $2 \cdot 1$ \\
\hline ,, 23 & $21 \cdot 0$ & $78 \cdot 0$ & nil & 0.8 & $16 \cdot 2$ & 14 & $1 \cdot 16$ & 90.5 & 84 & 1.08 & $0 \cdot 2$ & $2 \cdot 9$ \\
\hline
\end{tabular}

Table 30: L3.

Sept. $8 \quad 21 \cdot 4 \quad 105 \cdot 3$

$\begin{array}{llll},, & 16 & 21.4 & 102.5\end{array}$

$\begin{array}{llll},, & 30 & 21.5 & 104 \cdot 2\end{array}$

Oct. $14 \quad 21.6 \quad 108.2$

$\begin{array}{llll}, \quad & 28 & 21.7 & 106.0\end{array}$

Nov. $11 \quad 22.0 \quad 110.2$

$\begin{array}{llll},, & 25 & 22.0 & 109 \cdot 4\end{array}$

$\begin{array}{lrrr}\text { Dec. } & 9 & 22.0 & 110.4\end{array}$

$\begin{array}{llll}\text {,, } & 23 & 22.1 & 111.9\end{array}$

\begin{tabular}{|c|c|c|c|c|}
\hline nil & $-2 \cdot 8$ & $10 \cdot 4$ & 8 & $1 \cdot 30$ \\
\hline $0 \cdot 1$ & $1 \cdot 7$ & $21 \cdot 1$ & 14 & $1 \cdot 51$ \\
\hline $0 \cdot 1$ & $4 \cdot 0$ & $21 \cdot 1$ & 14 & $1 \cdot 51$ \\
\hline $0 \cdot 1$ & $-2 \cdot 2$ & $16 \cdot 5$ & 14 & $1 \cdot 16$ \\
\hline $0 \cdot 3$ & $4 \cdot 2$ & $19 \cdot 4$ & 14 & $1 \cdot 39$ \\
\hline nil & -0.8 & $14 \cdot 8$ & 14 & 1.06 \\
\hline nil & $1 \cdot 0$ & $12 \cdot 1$ & 14 & 0.86 \\
\hline $0 \cdot 1$ & $1 \cdot 5$ & 18.9 & 14 & $1 \cdot 35$ \\
\hline
\end{tabular}

Tabie 31: L2.

\begin{tabular}{rrrrr}
\multicolumn{2}{r}{ nil -0.8} & $\overline{17 \cdot 5}$ & $\overline{14}$ & $1 \cdot 25$ \\
nil & $-5 \cdot 8$ & $17 \cdot 6$ & 14 & 1.26 \\
nil & $3 \cdot 4$ & $23 \cdot 4$ & 14 & $1 \cdot 67$ \\
$0 \cdot 1$ & $3 \cdot 0$ & $23 \cdot 5$ & 14 & $1 \cdot 68$ \\
$0 \cdot 1$ & $-6 \cdot 5$ & $16 \cdot 8$ & 14 & $1 \cdot 20$ \\
nil & $7 \cdot 3$ & $24 \cdot 3$ & 14 & $1 \cdot 74$ \\
$0 \cdot 1$ & $-1 \cdot 1$ & $18 \cdot 1$ & 14 & $1 \cdot 29$ \\
nil & $1 \cdot 3$ & $12 \cdot 9$ & 14 & $0 \cdot 92$ \\
nil & $0 \cdot 2$ & $20 \cdot 4$ & 14 & $1 \cdot 46$
\end{tabular}

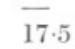

$35 \cdot 1$

$58 \cdot 5$

$82 \cdot 0$

$98 \cdot 8$

$123 \cdot 1$

$141 \cdot 2$

$154 \cdot 1$

$174 \cdot 5$

$10 \cdot 4$
$31 \cdot 5$
$52 \cdot 6$
$69 \cdot 1$
$88 \cdot 5$
$103 \cdot 3$
$115 \cdot 4$
$134 \cdot 3$

-
22
36
50
64
78
92
106

$\overline{1 \cdot 30}$

1.43

$1 \cdot 46$

1. 38

$1 \cdot 38$

$1 \cdot 32$

$1 \cdot 25$

$1 \cdot 27$

nil -2.8

$0 \cdot 1-1 \cdot 1$

$0 \cdot 2 \quad 2 \cdot 9$

$0.3 \quad 0.7$

$0 \cdot 6 \quad 4 \cdot 9$

$0 \cdot 6 \quad 4 \cdot 1$

$0 \cdot 6 \quad 5 \cdot 1$

$\begin{array}{ll}0.7 & 6 \cdot 6\end{array}$

\section{TABLE 32.}

Maintenance in the Male Plaice, L2a and L1a.

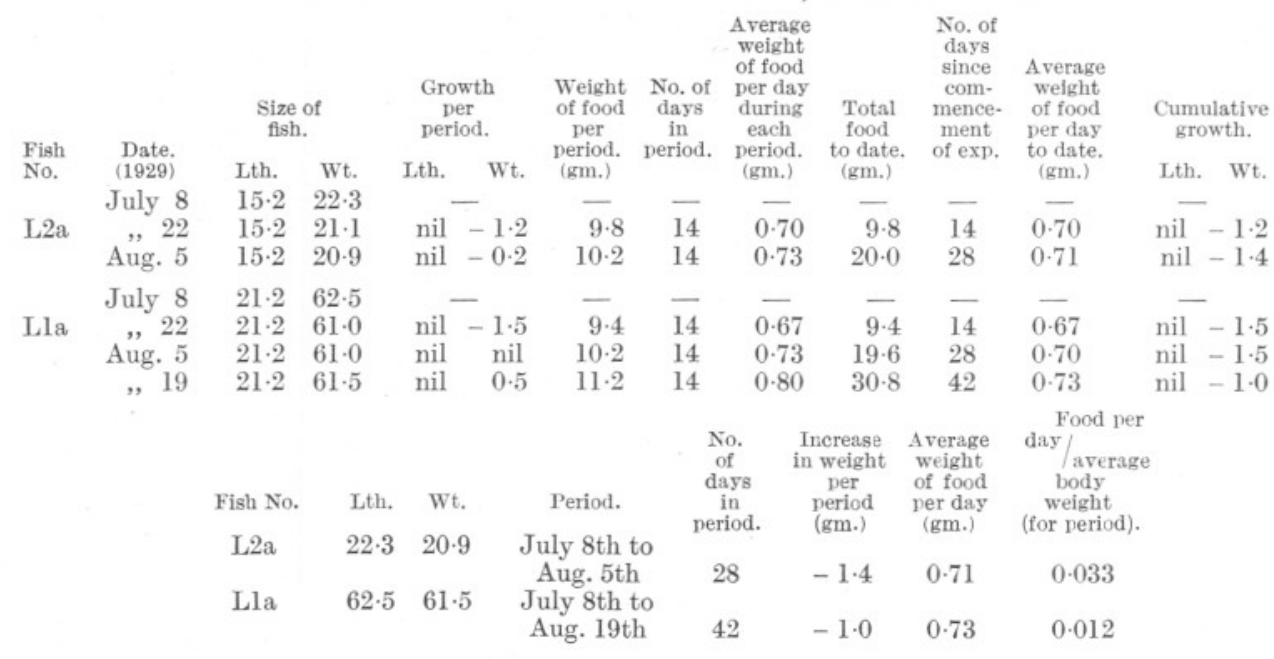


TABLE 33.

Maintenance in the Male Plaice, L1, L4b, L3, and L2.

\begin{tabular}{|c|c|c|c|c|c|c|c|c|c|c|c|c|c|}
\hline & & $50 \cdot 3$ & L1 & $53 \cdot 7$ & $75 \cdot 1$ & L4B & $78 \cdot 0$ & $105 \cdot 3$ & L3 & 111.9 & $129 \cdot 9$ & L2 & $130 \cdot 9$ \\
\hline $\begin{array}{l}\text { Date. } \\
(1929)\end{array}$ & $\begin{array}{l}\text { No. of } \\
\text { days } \\
\text { in } \\
\text { period. }\end{array}$ & $\begin{array}{c}\text { Inerease } \\
\text { in } \\
\text { weight } \\
\text { per } \\
\text { period. } \\
\text { (gm.) }\end{array}$ & $\begin{array}{c}\text { Food per } \\
\text { day/ } \\
\text { /average } \\
\text { body-wt. } \\
\text { (for period). }\end{array}$ & $\begin{array}{c}\text { Food per } \\
\text { day//mid } \\
\text { body-wt. } \\
\text { (to date). }\end{array}$ & $\begin{array}{c}\text { Increase } \\
\text { in } \\
\text { weight } \\
\text { per } \\
\text { period. } \\
\text { (gm.) }\end{array}$ & $\begin{array}{c}\text { Food per } \\
\text { day/ } \\
\text { /average } \\
\text { body-wt. } \\
\text { (for period). }\end{array}$ & $\begin{array}{l}\text { Food per } \\
\text { day } / \text { mid } \\
\text { body-wt. } \\
\text { (to date). }\end{array}$ & $\begin{array}{c}\text { Increase } \\
\text { in } \\
\text { weight } \\
\text { per } \\
\text { period. } \\
\text { (gm.) }\end{array}$ & $\begin{array}{l}\text { Focd per } \\
\text { day/ } \\
\text { body-wt. } \\
\text { (for period). }\end{array}$ & $\begin{array}{l}\text { Food per } \\
\text { day/ } / \text { mid } \\
\text { body-wt. } \\
\text { (to date). }\end{array}$ & $\begin{array}{c}\text { Increase } \\
\text { in } \\
\text { weight } \\
\text { per } \\
\text { period. } \\
\text { (gm.) }\end{array}$ & $\begin{array}{c}\text { Food per } \\
\text { day/ } \\
\text { bodyerage } \\
\text { bodt. } \\
\text { (for period). }\end{array}$ & $\begin{array}{l}\text { Food per } \\
\text { day//mid } \\
\text { body-wt. } \\
\text { (to date). }\end{array}$ \\
\hline Aug. 19* & - & - & - & - & - & - & - & - & - & - & - & - & - \\
\hline Sept. $2 \dagger$ & 14 & $-1 \cdot 3$ & 0.015 & 0.015 & - & - & - & - & - & - & -0.8 & 0.010 & 0.010 \\
\hline$\Rightarrow \quad 16$ & 14 & $-1 \cdot 3$ & 0.018 & 0.016 & - & - & - & $-2 \cdot 8$ & 0.013 & 0.013 & $-5 \cdot 8$ & 0.010 & 0.010 \\
\hline 30 & 14 & $2 \cdot 2$ & 0.019 & 0.017 & - & - & - & $1 \cdot 7$ & 0.015 & $0 \cdot 014$ & $3 \cdot 4$ & 0.013 & 0.011 \\
\hline Oct. 14 & 14 & $3 \cdot 2$ & 0.019 & 0.017 & $2 \cdot 6$ & 0.013 & 0.013 & $4 \cdot 0$ & 0.014 & 0.014 & $3 \cdot 0$ & 0.013 & 0.011 \\
\hline 28 & 14 & $-0 \cdot 4$ & $0 \cdot 017$ & 0.017 & $-2 \cdot 6$ & 0.010 & 0.012 & $-2 \cdot 2$ & $0 \cdot 011$ & 0.013 & -6.5 & $0 \cdot 009$ & 0.011 \\
\hline Nov. 11 & 14 & $1 \cdot 8$ & 0.018 & 0.017 & $2 \cdot 1$ & $0 \cdot 018$ & $0 \cdot 014$ & $4 \cdot 2$ & $0 \cdot 013$ & 0.013 & $7 \cdot 3$ & $0 \cdot 014$ & $0 \cdot 011$ \\
\hline 25 & 14 & $-0 \cdot 4$ & $0 \cdot 017$ & 0.017 & $-0 \cdot 3$ & $0 \cdot 017$ & 0.015 & -0.8 & $0 \cdot 010$ & 0.012 & $-1 \cdot 1$ & $0 \cdot 010$ & $0 \cdot 011$ \\
\hline Dec. 9 & 14 & $0 \cdot 3$ & $0 \cdot 011$ & 0.016 & $0 \cdot 3$ & 0.011 & 0.014 & $1 \cdot 0$ & $0 \cdot 008$ & 0.013 & $1 \cdot 3$ & 0.007 & 0.011 \\
\hline , 23 & 14 & -0.7 & 0.014 & 0.016 & 0.8 & 0.015 & $0 \cdot 014$ & $1 \cdot 5$ & 0.012 & 0.012 & $0 \cdot 2$ & 0.011 & 0.011 \\
\hline
\end{tabular}

* August 22nd for L1. † September 8th for L3. 
TABLES 34-37.

\section{Maintenance in Female Plaice.}

Table 34: L5.

\begin{tabular}{|c|c|c|c|c|c|c|c|c|c|c|c|c|}
\hline \multirow{2}{*}{$\begin{array}{l}\text { Date. } \\
(1929)\end{array}$} & \multicolumn{2}{|c|}{$\begin{array}{l}\text { Size } \\
\text { of } \\
\text { fish. }\end{array}$} & \multicolumn{2}{|c|}{$\begin{array}{c}\text { Growth } \\
\text { Der } \\
\text { period. }\end{array}$} & \multirow{2}{*}{$\begin{array}{c}\text { Weight } \\
\text { of food } \\
\text { per } \\
\text { period. } \\
\text { (gm.) }\end{array}$} & \multirow[t]{2}{*}{$\begin{array}{c}\text { No. of } \\
\text { days } \\
\text { in } \\
\text { period. }\end{array}$} & \multirow{2}{*}{$\begin{array}{l}\text { Average } \\
\text { wt. of } \\
\text { food } \\
\text { per day } \\
\text { for each } \\
\text { period. } \\
\text { (gm.) }\end{array}$} & \multirow{2}{*}{$\begin{array}{c}\text { Total } \\
\text { food } \\
\text { to date. } \\
\text { (gm.) }\end{array}$} & \multirow[t]{2}{*}{$\begin{array}{c}\text { No. of } \\
\text { days } \\
\text { since } \\
\text { commence- } \\
\text { ment } \\
\text { of expt. }\end{array}$} & \multirow{2}{*}{$\begin{array}{c}\text { A verage } \\
\text { wt. of } \\
\text { food } \\
\text { per day } \\
\text { to date. } \\
\text { (gm.) }\end{array}$} & \multicolumn{2}{|c|}{$\begin{array}{l}\text { Cumulative } \\
\text { growth. }\end{array}$} \\
\hline & Lth. & Wt. & Lth. & Wt. & & & & & & & Lth. & wt. \\
\hline Aug. 8 & $18 \cdot 5$ & $62 \cdot 8$ & & - & - & - & - & - & - & - & & \\
\hline , 19 & $18 \cdot 5$ & $60 \cdot 5$ & nil & $-2 \cdot 3$ & 8.8 & 11 & 0.80 & 8.8 & 11 & 0.80 & nil & $-2 \cdot 3$ \\
\hline Sept. 2 & $18 \cdot 5$ & $59 \cdot 3$ & nil & $-1 \cdot 2$ & $11 \cdot 8$ & 14 & $0 \cdot 84$ & $20 \cdot 6$ & 25 & 0.82 & nil & $-3 \cdot 5$ \\
\hline , 16 & & & & $=$ & $13 \cdot 2$ & 14 & 0.94 & 33.8 & 39 & 0.87 & & \\
\hline , 30 & $18 \cdot 4$ & $62 \cdot 2$ & $-0 \cdot 1$ & $2 \cdot 9$ & $13 \cdot 2$ & 14 & 0.94 & $47 \cdot 0$ & 53 & 0.89 & -0.1 & $-0 \cdot 6$ \\
\hline ct. 14 & $18 \cdot 4$ & $65 \cdot 7$ & nil & $3 \cdot 5$ & $15 \cdot 3$ & 14 & 1.09 & $62 \cdot 3$ & 67 & 0.93 & -0.1 & $2 \cdot 9$ \\
\hline , $\quad 28$ & $18 \cdot 5$ & $65 \cdot 3$ & $0 \cdot 1$ & -0.4 & $11 \cdot 1$ & 14 & $0 \cdot 79$ & $73 \cdot 4$ & 81 & 0.91 & nil & $2 \cdot 5$ \\
\hline Nov. 11 & 18.6 & $65 \cdot 6$ & 0.1 & 0.3 & $11 \cdot 3$ & 14 & 0.81 & $84 \cdot 7$ & 95 & $0 \cdot 89$ & $0 \cdot 1$ & $2 \cdot 8$ \\
\hline,$\quad 25$ & $18 \cdot 6$ & $66 \cdot 9$ & nil & $1 \cdot 3$ & $11 \cdot 3$ & 14 & $0 \cdot 81$ & $96 \cdot 0$ & 109 & $0 \cdot 88$ & $0 \cdot 1$ & $4 \cdot 1$ \\
\hline Dec. 9 & $18 \cdot 7$ & $67 \cdot 0$ & $0 \cdot 1$ & 0.1 & $6 \cdot 2$ & 14 & 0.44 & $102 \cdot 2$ & 123 & $0 \cdot 83$ & $0 \cdot 2$ & $4 \cdot 2$ \\
\hline,,$\quad 23$ & $18 \cdot 7$ & $67 \cdot 5$ & nil & 0.5 & $10 \cdot 4$ & 14 & $0 \cdot 74$ & $112 \cdot 6$ & 137 & $0-82$ & $0 \cdot 2$ & $4 \cdot 7$ \\
\hline
\end{tabular}

TABLe 35: L6.

Sept. $16 \quad 19 \cdot 2 \quad 71 \cdot 2$ $\begin{array}{llll}\text {, } & 30 & 19 \cdot 2 & 70 \cdot 5\end{array}$

$\begin{array}{llll}\text { Oct. } & 14 & 19 \cdot 2 & 73.5\end{array}$ $\begin{array}{rrr},, & 28 & 19 \cdot 2 \quad 70 \cdot 3\end{array}$

$\begin{array}{lll}\text { Nov. } 11 & 19 \cdot 2 & 71 \cdot 7\end{array}$

$\begin{array}{llll}\quad & 25 & 19 \cdot 3 & 70 \cdot 1\end{array}$

$\begin{array}{lrrr}\text { Dec. } & 9 & 19 \cdot 3 & 69 \cdot 9\end{array}$

$\begin{array}{llll}\text {, } & 23 & 19 \cdot 3 & 70 \cdot 4\end{array}$

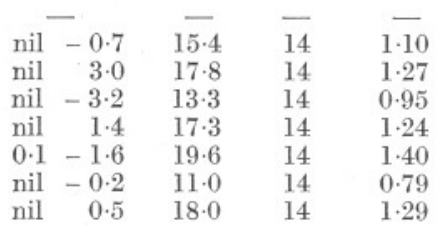

TABLe $36: \mathrm{L} 7$.

Sept. $4 \quad 22 \cdot 3 \quad 104 \cdot 8$ $\begin{array}{llll},, & 16 & 22 \cdot 3 & 100 \cdot 1\end{array}$ $\begin{array}{llll}\text {," } & 30 & 22.4 & 97 \cdot 5\end{array}$

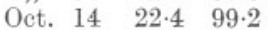

$\begin{array}{llll}\text {, } & 28 & 22.4 & 94.4\end{array}$

Nov. $11 \quad 22.5 \quad 99.5$

$\begin{array}{llll}\text {, } & 25 & 22.7 & 100 \cdot 6\end{array}$

$\begin{array}{lrrr}\text { Dec. } \quad 9 & 22.7 & 99 \cdot 8\end{array}$

$\begin{array}{lrrr}\text {,, } 2322.7 & 100.0\end{array}$

$1 \cdot 30$
$1 \cdot 30$
$1 \cdot 40$
$1 \cdot 17$
$1 \cdot 46$
$1 \cdot 26$
$0 \cdot 76$
$1 \cdot 19$

$\overline{15 \cdot 6}$

$33 \cdot 8$

$53 \cdot 4$

$69 \cdot 8$

$90 \cdot 3$

$108 \cdot 0$

$118 \cdot 6$

$135 \cdot 2$

714
28
42
56
70
84
98

$\overline{1.10}$

1.19 nil 2.3

1.11 nil -0.9

1.14 nil 0.5

$\begin{array}{lll}1.19 & 0.1 & -1.1\end{array}$

$\begin{array}{lll}1.12 & 0.1 & -1.3\end{array}$

$\begin{array}{lll}1.15 & 0.1 & -0.8\end{array}$

Table 37: L8.

Aug. $22 \quad 21.9 \quad 102.0$

Sept. $2 \quad 22.0 \quad 102.1$

$\begin{array}{lllll}\text {, } & 16 & 22.0 & 102.8\end{array}$

$\begin{array}{llll}\text {, } & 30 & 22.1 & 104.5\end{array}$

Oct. $16 \quad 23.0 \quad 114 \cdot 0$

, $28 \quad 23 \cdot 1 \quad 111 \cdot 3$

Nov. $11 \quad 23.2114 .0$

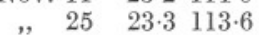

$\begin{array}{lrll}\text { Dec. } 9 & 93.3 & 114 \cdot 2\end{array}$

, 2323.3116 .5

$\begin{array}{lll}0 \cdot 1 & 0 \cdot 1 & 14 \cdot 3 \\ \text { nil } & 0 \cdot 7 & 18 \cdot 2 \\ 0 \cdot 1 & 1 \cdot 7 & 19 \cdot 0\end{array}$

-11
14
14
-
12
14
14
14
14

$\begin{array}{rrrr}0 \cdot 1 & -2 \cdot 7 & 16 \cdot 8 & 12 \\ 0 \cdot 1 & 2 \cdot 7 & 23 \cdot 4 & 14 \\ 0 \cdot 1 & -0 \cdot 4 & 20 \cdot 2 & 14 \\ \text { nil } & 0 \cdot 6 & 13 \cdot 4 & 14 \\ \text { nil } & 2 \cdot 3 & 20 \cdot 8 & 14\end{array}$

$\overline{14 \cdot 3}$

$32 \cdot 5$

$51 \cdot 5$

$\overline{1 \cdot 40}$

$\overline{16 \cdot 8}$

$40 \cdot 2$

$60 \cdot 4$

$73 \cdot 8$

$94 \cdot 6$
1.67
1.44

0.96

$1 \cdot 49$

-12
26
40
54
68
82
96
110

1.30

$1 \cdot 30$

$1 \cdot 33$

$1 \cdot 29$

$1 \cdot 33$

$1 \cdot 32$

1.24

1. 23

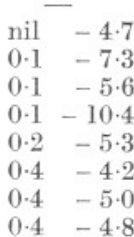

11
25
39
-
12
2
4
5

1. 30

$1 \cdot 30$

$1 \cdot 32$

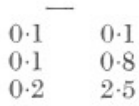

$\overline{1.40}$

$1 \cdot 55$

1.51

$1 \cdot 37$

$1 \cdot 39$

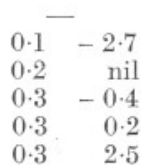


TABLE 38.

Matntenance in the Female Plaice, L5, L6, L7, and L8

(a \& b).

\begin{tabular}{|c|c|c|c|c|c|c|c|c|c|c|c|c|c|}
\hline & & $62 \cdot 8$ & L5 & $67 \cdot 5$ & $71 \cdot 2$ & L6 & $70 \cdot 4$ & $104 \cdot 8$ & L7 & $100 \cdot 0$ & $\begin{array}{l}\begin{array}{l}102 \cdot 0 \\
114 \cdot 0\end{array}\end{array}$ & $L 8_{\mathrm{b}}^{\mathrm{a}}$ & $\begin{array}{l}104 \cdot 5 \\
116 \cdot 5\end{array}$ \\
\hline $\begin{array}{l}\text { Date. } \\
(1929)\end{array}$ & $\begin{array}{c}\text { No. of } \\
\text { days } \\
\text { in } \\
\text { period. }\end{array}$ & $\begin{array}{c}\text { Increase } \\
\text { in } \\
\text { weight } \\
\text { per } \\
\text { period. } \\
\text { (gm.) }\end{array}$ & $\begin{array}{c}\text { Food per } \\
\text { day//2verage } \\
\text { body-wt. } \\
\text { (for period). }\end{array}$ & $\begin{array}{l}\text { Food per } \\
\text { day } / \text { mid } \\
\text { body-wt. } \\
\text { (to date). }\end{array}$ & $\begin{array}{c}\text { Increase } \\
\text { in } \\
\text { weight } \\
\text { per } \\
\text { period. } \\
\text { (gm.) }\end{array}$ & $\begin{array}{l}\text { Food per } \\
\text { day// } \\
\text { /average } \\
\text { body-wt. } \\
\text { (for period). }\end{array}$ & $\begin{array}{l}\text { Food per } \\
\text { day/ } \\
\text { /mid } \\
\text { body-wt. } \\
\text { (to date). }\end{array}$ & $\begin{array}{c}\text { Increase } \\
\text { in } \\
\text { weight } \\
\text { per } \\
\text { period. } \\
\text { (gm.) }\end{array}$ & $\begin{array}{l}\text { Food per } \\
\text { daly / } \\
\text { /average } \\
\text { body-wt. } \\
\text { (for period). }\end{array}$ & $\begin{array}{l}\text { Food per } \\
\text { day/mid } \\
\text { body-wt. } \\
\text { bodte date). }\end{array}$ & $\begin{array}{c}\text { Increase } \\
\text { in } \\
\text { weight } \\
\text { per } \\
\text { period. } \\
\text { (gm.) }\end{array}$ & $\begin{array}{l}\text { Food per } \\
\text { day/ } \\
\text { /average } \\
\text { body-wt. } \\
\text { (for period). }\end{array}$ & $\begin{array}{l}\text { Food per } \\
\text { day/mid } \\
\text { body-wt. } \\
\text { (to date). }\end{array}$ \\
\hline Aug. 8 & - & & & & - & & & - & & & - & & \\
\hline$\Rightarrow \quad 19 \dagger$ & 11 & $-2 \cdot 3$ & 0.013 & 0.013 & & & & & & & - & & \\
\hline Sept. $2^{*}$ & 14 & $-1 \cdot 2$ & 0.014 & 0.013 & & & & - & & & $0 \cdot 1$ & 0.013 & 0.013 \\
\hline$\Rightarrow \quad 16$ & 14 & - & - & - & - & & & $-4 \cdot 7$ & 0.013 & 0.013 & $0 \cdot 7$ & 0.013 & 0.013 \\
\hline 30 & 14 & 2.9 & 0.015 & 0.014 & -0.7 & $0 \cdot 016$ & 0.016 & $-2 \cdot 6$ & 0.013 & 0.013 & 1.7 & 0.013 & 0.013 \\
\hline Oct. $14 \ddagger$ & 14 & $3 \cdot 5$ & 0.017 & 0.014 & $3 \cdot 0$ & 0.018 & 0.016 & 1.7 & 0.014 & 0.013 & - & & \\
\hline$\Rightarrow \quad 28$ & 14 & $-0 \cdot 4$ & 0.012 & 0.014 & $-3 \cdot 2$ & 0.013 & 0.016 & $-4 \cdot 8$ & 0.012 & 0.013 & $-2 \cdot 7$ & $0 \cdot 012$ & 0.012 \\
\hline Nov. 11 & 14 & $0 \cdot 3$ & 0.012 & 0.014 & $1 \cdot 4$ & 0.017 & 0.016 & $5 \cdot 1$ & 0.015 & 0.013 & $2 \cdot 7$ & 0.015 & 0.014 \\
\hline 25 & 14 & $1 \cdot 3$ & 0.012 & 0.014 & $-1 \cdot 6$ & 0.020 & 0.017 & $1 \cdot 1$ & 0.013 & 0.013 & $-0 \cdot 4$ & 0.013 & 0.013 \\
\hline Dec. 9 & 14 & $0 \cdot 1$ & 0.007 & 0.013 & $-0 \cdot 2$ & 0.011 & $0 \cdot 016$ & $-0 \cdot 8$ & 0.008 & 0.012 & $0 \cdot 6$ & 0.008 & 0.012 \\
\hline$\Rightarrow \quad 23$ & 14 & 0.5 & $0 \cdot 011$ & 0.013 & 0.5 & 0.018 & $0 \cdot 016$ & $0 \cdot 2$ & 0.012 & 0.012 & $2 \cdot 3$ & 0.013 & 0.012 \\
\hline
\end{tabular}


TABLE 39.

Maintenance in the Female Plaice, L6a, L5a, L8c, and L7a.

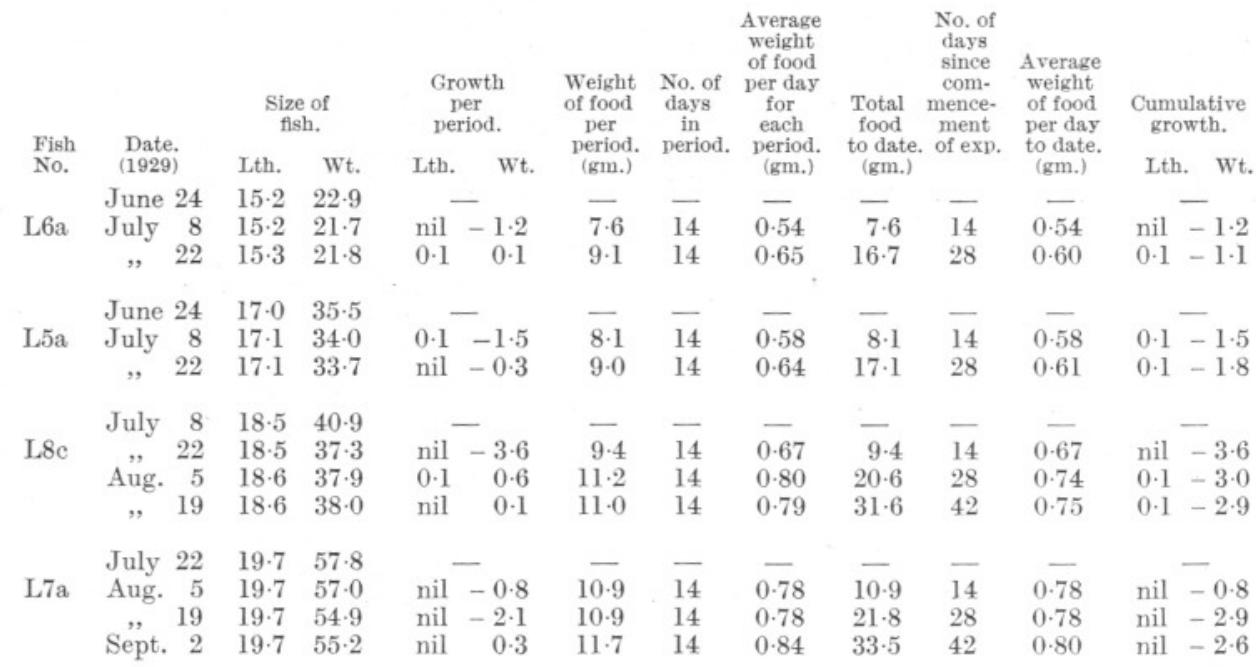

TABLE 40.

Maintenance in the Female Plaice, L6a, L5a, L8c, and L7a.

\begin{tabular}{|c|c|c|c|c|c|c|c|c|}
\hline $\begin{array}{l}\text { Fish } \\
\text { No. }\end{array}$ & Period. & $\begin{array}{c}\text { No. of } \\
\text { days } \\
\text { in } \\
\text { period. }\end{array}$ & $\begin{array}{c}\text { Initial } \\
\text { weight. } \\
\text { (gm.) }\end{array}$ & $\begin{array}{c}\text { Final } \\
\text { weight. } \\
\text { (gm.) }\end{array}$ & $\begin{array}{c}\text { Increase } \\
\text { in } \\
\text { weight. } \\
\text { (gm.) }\end{array}$ & $\begin{array}{c}\text { Food } \\
\text { per } \\
\text { period. } \\
\text { (gm.) }\end{array}$ & $\begin{array}{c}\text { A verage } \\
\text { weight } \\
\text { of food } \\
\text { per day. } \\
\text { (gm.) }\end{array}$ & $\begin{array}{c}\text { Food per } \\
\text { day/ } \\
\text { /average } \\
\text { body-wt. } \\
\text { (for } \\
\text { period). }\end{array}$ \\
\hline L6a & June 24-July 22 & 28 & $22 \cdot 9$ & $21 \cdot 8$ & $-1 \cdot 1$ & $16 \cdot 7$ & $0 \cdot 60$ & $0 \cdot 027$ \\
\hline L5a & , & 28 & $35 \cdot 5$ & $33 \cdot 7$ & $-1 \cdot 8$ & $17 \cdot 1$ & $0 \cdot 61$ & 0.018 \\
\hline L8c & July 22-Aug. 19 & 28 & $37 \cdot 3$ & $38 \cdot 0$ & $0 \cdot 7$ & $22 \cdot 2$ & $0 \cdot 79$ & 0.021 \\
\hline L7a & July 22-Sept. 2 & 42 & $57 \cdot 8$ & $55 \cdot 2$ & $-2 \cdot 6$ & $33 \cdot 5$ & $0 \cdot 80$ & 0.014 \\
\hline
\end{tabular}


TABLE 41.

Maximum Requirements and Growth.

\begin{tabular}{|c|c|c|}
\hline $\begin{array}{l}\text { Fish. } \\
\text { No. }\end{array}$ & Sex. & $\begin{array}{l}\text { Period. } \\
\text { (1929) }\end{array}$ \\
\hline L11 & $\hat{o}$ & June 24-Nov. 25 \\
\hline L10 & $\hat{o}$ & June 24-Sept. 30 \\
\hline $\mathrm{L} 12$ & $\hat{0}$ & June 24-Nov. 25 \\
\hline L9 & $\sigma^{\circ}$ & June 24-Sept. 30 \\
\hline L13 & 우 & June 24-Nov. 25 \\
\hline L15 & 우 & June 24-Nov. 25 \\
\hline L16 & 우 & June 24-Nov. 25 \\
\hline L14 & 우 & July 15-Nov. 25 \\
\hline
\end{tabular}

\section{HAXMUM REQUTEMENTS AND GROWTH.}

\begin{tabular}{|c|c|c|c|c|c|c|c|}
\hline \multirow{2}{*}{$\begin{array}{c}\text { No. of } \\
\text { days } \\
\text { in } \\
\text { period. }\end{array}$} & \multicolumn{2}{|c|}{$\begin{array}{c}\text { Initial } \\
\text { size. }\end{array}$} & $\begin{array}{l}\text { Final } \\
\text { size. }\end{array}$ & Growth. & \multirow{2}{*}{$\begin{array}{l}\text { Total } \\
\text { food } \\
\text { per the } \\
\text { period. } \\
\text { (gm.) }\end{array}$} & \multirow{2}{*}{$\begin{array}{l}\text { Average } \\
\text { weight } \\
\text { of food } \\
\text { per day } \\
\text { for the } \\
\text { period. } \\
\text { (gm.) }\end{array}$} & \multirow[t]{2}{*}{$\begin{array}{l}\text { Gm. of } \\
\text { food per } \\
1.0 \mathrm{gm} . \\
\text { increase } \\
\text { in weight } \\
\text { of fish. }\end{array}$} \\
\hline & Lth. & wt. & Lth. Wt. & Lth. Wt. & & & \\
\hline 154 & $16 \cdot 1$ & $23 \cdot 2$ & $23 \cdot 1 \quad 157 \cdot 4$ & $\begin{array}{lll}7 \cdot 0 & 134 \cdot 2\end{array}$ & 953 & $6 \cdot 2$ & $7 \cdot 1$ \\
\hline 98 & $16 \cdot 6$ & $36 \cdot 2$ & $\begin{array}{ll}19 \cdot 1 & 82 \cdot 8\end{array}$ & $46 \cdot 6$ & 536 & $5 \cdot 5$ & $11 \cdot 5$ \\
\hline 154 & $18 \cdot 1$ & $44 \cdot 0$ & $21 \cdot 8 \quad 111 \cdot 4$ & $67 \cdot 4$ & 758 & $4 \cdot 9$ & $11 \cdot 2$ \\
\hline 98 & $19 \cdot 7$ & $57 \cdot 5$ & $21 \cdot 3 \quad 102 \cdot 6$ & $45 \cdot 1$ & 676 & $6 \cdot 9$ & $15 \cdot 0$ \\
\hline 154 & $15 \cdot 1$ & $27 \cdot 0$ & $19 \cdot 2 \quad 70 \cdot 4$ & $4 \cdot 1 \quad 43 \cdot 4$ & 626 & $4 \cdot 1$ & $14 \cdot 4$ \\
\hline 154 & $15 \cdot 1$ & $31 \cdot 9$ & $23 \cdot 0 \quad 140 \cdot 7$ & $\begin{array}{lll}7 \cdot 9 & 108 \cdot 8\end{array}$ & 883 & $5 \cdot 7$ & $8 \cdot 1$ \\
\hline 154 & $18 \cdot 4$ & $50 \cdot 5$ & $24 \cdot 1 \quad 175 \cdot 0$ & $5 \cdot 7 \quad 124 \cdot 5$ & 1060 & $6 \cdot 9$ & $8 \cdot 5$ \\
\hline 133 & $23 \cdot 0$ & $90 \cdot 1$ & $25 \cdot 7 \quad 184 \cdot 8$ & $\begin{array}{ll}2 \cdot 7 & 94.7\end{array}$ & 905 & 6.8 & $9 \cdot 6$ \\
\hline
\end{tabular}


TABLES 42-45.

Maximum Requirements and Growth of Male Platce.

TABLe 42 : L11.

\begin{tabular}{|c|c|c|c|c|c|c|c|c|c|c|c|c|c|}
\hline \multirow[b]{2}{*}{$\begin{array}{l}\text { Date. } \\
\text { (1929) }\end{array}$} & \multicolumn{2}{|c|}{$\begin{array}{l}\text { Size } \\
\text { of } \\
\text { fish. }\end{array}$} & \multirow[t]{2}{*}{ Wt./Lth." } & \multirow{2}{*}{\multicolumn{2}{|c|}{$\begin{array}{l}\text { Growth } \\
\text { per } \\
\text { period. } \\
\text { Lth. Wt. } \\
\text { (cm.) (gm.) }\end{array}$}} & \multirow{2}{*}{$\begin{array}{l}\text { Total } \\
\text { food } \\
\text { per } \\
\text { period. } \\
\text { (gm.) }\end{array}$} & \multirow[t]{2}{*}{$\begin{array}{l}\text { Gm. of } \\
\text { food } \\
\text { per } \\
1.0 \mathrm{gm} \text {. } \\
\text { increase } \\
\text { in } \\
\text { weight } \\
\text { of flsh. }\end{array}$} & \multirow[t]{2}{*}{$\begin{array}{c}\text { No. of } \\
\text { days } \\
\text { in } \\
\text { period. }\end{array}$} & \multirow{2}{*}{$\begin{array}{c}\text { Average } \\
\text { food } \\
\text { per day } \\
\text { during } \\
\text { each } \\
\text { period. } \\
\text { (gm.) }\end{array}$} & \multicolumn{2}{|c|}{$\begin{array}{l}\text { Cumulative } \\
\text { growth. }\end{array}$} & \multirow{2}{*}{$\begin{array}{c}\text { Total } \\
\text { food } \\
\text { to date. } \\
\text { (gm.) }\end{array}$} & \multirow[t]{2}{*}{$\begin{array}{l}\mathrm{Gm} \text {. of } \\
\text { food per } \\
1.0 \mathrm{gm} \text {. } \\
\text { increase } \\
\text { in wt. } \\
\text { of fish } \\
\text { to date. }\end{array}$} \\
\hline & $\begin{array}{l}\text { Lth. } \\
\text { (em.) }\end{array}$ & $\begin{array}{l}\text { Wt. } \\
\text { (gm.) }\end{array}$ & & & & & & & & Lth. & Wt. & & \\
\hline June 24 & $16 \cdot 1$ & $23 \cdot 2$ & 0.006 & & & - & - & - & - & & 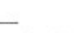 & - & - \\
\hline July 8 & $17 \cdot 4$ & 48.5 & 0.009 & $1 \cdot 3$ & $25 \cdot 3$ & $57 \cdot 2$ & $2 \cdot 3$ & 14 & $4 \cdot 1$ & $1 \cdot 3$ & $25 \cdot 3$ & 57 & $2 \cdot 3$ \\
\hline , 22 & $17 \cdot 8$ & $61 \cdot 2$ & 0.011 & 0.4 & $12 \cdot 7$ & 85.0 & $6 \cdot 7$ & 14 & $6 \cdot 1$ & 1.7 & 38.0 & 142 & $3 \cdot 7$ \\
\hline Aüg. 5 & $18 \cdot 2$ & $66 \cdot 7$ & 0.011 & 0.4 & $5 \cdot 5$ & $98 \cdot 0$ & $17 \cdot 8$ & 14 & $7 \cdot 0$ & $2 \cdot 1$ & $43 \cdot 5$ & 240 & $5 \cdot 5$ \\
\hline , 19 & $19 \cdot 2$ & $83 \cdot 1$ & 0.012 & $1 \cdot 0$ & $16 \cdot 4$ & $100 \cdot 4$ & $6 \cdot 1$ & 14 & $7 \cdot 2$ & $3 \cdot 1$ & $59 \cdot 9$ & 340 & $5 \cdot 7$ \\
\hline Sept. 2 & $20 \cdot 0$ & $97 \cdot 1$ & 0.012 & $0 \cdot 8$ & $14 \cdot 0$ & $102 \cdot 3$ & $7 \cdot 3$ & 14 & $7 \cdot 3$ & $3 \cdot 9$ & $73 \cdot 9$ & 443 & $6 \cdot 0$ \\
\hline,$\quad 16$ & $20 \cdot 4$ & $106 \cdot 0$ & 0.012 & $0 \cdot 4$ & $8 \cdot 9$ & $102 \cdot 0$ & $11 \cdot 5$ & 14 & $7 \cdot 3$ & $4 \cdot 3$ & $82 \cdot 8$ & 545 & $6 \cdot 6$ \\
\hline ,, 30 & $21 \cdot 3$ & $122 \cdot 8$ & 0.013 & $0 \cdot 9$ & $16 \cdot 8$ & $104 \cdot 4$ & $6 \cdot 2$ & 14 & $7 \cdot 5$ & $5 \cdot 2$ & $99 \cdot 6$ & 649 & $6 \cdot 5$ \\
\hline Oct. 14 & $21 \cdot 8$ & $138 \cdot 0$ & 0.013 & 0.5 & $15 \cdot 2$ & $105 \cdot 3$ & $6 \cdot 9$ & 14 & $7 \cdot 5$ & $5 \cdot 7$ & $114 \cdot 8$ & 755 & $6 \cdot 6$ \\
\hline , 28 & $22 \cdot 8$ & $149 \cdot 2$ & $0 \cdot 013$ & $1 \cdot 0$ & $11 \cdot 2$ & $92 \cdot 0$ & $8 \cdot 2$ & 14 & $6 \cdot 6$ & $6 \cdot 7$ & $126 \cdot 0$ & 847 & $6 \cdot 7$ \\
\hline Nov. 11 & $23 \cdot 1$ & $158 \cdot 6$ & 0.013 & $0 \cdot 3$ & $9 \cdot 4$ & $79 \cdot 1$ & $8 \cdot 4$ & 14 & $5 \cdot 6$ & $7 \cdot 0$ & $135 \cdot 4$ & 926 & $6 \cdot 8$ \\
\hline,$\quad 25$ & $23 \cdot 1$ & $157 \cdot 4$ & 0.013 & nil & $-1 \cdot 2$ & $26 \cdot 6$ & - & 14 & 1.9 & $7 \cdot 0$ & $134 \cdot 2$ & 953 & $7 \cdot 1$ \\
\hline Dec. $\theta$ & $23 \cdot 1$ & $151 \cdot 6$ & 0.012 & nil & $-5 \cdot 8$ & $4 \cdot 6$ & - & 14 & $0 \cdot 3$ & $7 \cdot 0$ & $128 \cdot 4$ & 958 & $7 \cdot 5$ \\
\hline , $\quad 23$ & $23 \cdot 1$ & $147 \cdot 2$ & 0.012 & nil & $-4 \cdot 4$ & $5 \cdot 9$ & 一 & 14 & $0 \cdot 4$ & $7 \cdot 0$ & $124 \cdot 0$ & 963 & $7 \cdot 8$ \\
\hline & & & & & & E 4 & I & & & & & & \\
\hline June 24 & $16 \cdot 6$ & $36 \cdot 2$ & 0.008 & & & 一 & - & - & - & - & - & - & - \\
\hline July 8 & $16 \cdot 9$ & $42 \cdot 8$ & 0.009 & $0 \cdot 3$ & $6 \cdot 6$ & $52 \cdot 2$ & $7 \cdot 9$ & 14 & $3 \cdot 7$ & $0 \cdot 3$ & $6 \cdot 6$ & 52 & $7 \cdot 9$ \\
\hline ," 22 & $17 \cdot 4$ & $52 \cdot 8$ & 0.010 & $0 \cdot 5$ & $10 \cdot 0$ & $69 \cdot 7$ & $7 \cdot 0$ & 14 & $5 \cdot 0$ & 0.8 & $16 \cdot 6$ & 122 & $7 \cdot 3$ \\
\hline Aug. 5 & $17 \cdot 9$ & $62 \cdot 0$ & 0.011 & 0.5 & $9 \cdot 2$ & $84 \cdot 0$ & $9 \cdot 1$ & 14 & $6 \cdot 0$ & $1 \cdot 3$ & $25 \cdot 8$ & 206 & $8 \cdot 0$ \\
\hline ," 19 & $18 \cdot 4$ & $70 \cdot 3$ & $0 \cdot 011$ & $0 \cdot 5$ & $8 \cdot 3$ & $90 \cdot 7$ & $10 \cdot 9$ & 14 & $6 \cdot 5$ & $1 \cdot 8$ & $34 \cdot 1$ & 297 & $8 \cdot 7$ \\
\hline Sept. 2 & $18 \cdot 7$ & $77 \cdot 5$ & 0.012 & $0 \cdot 3$ & $7 \cdot 2$ & $94 \cdot 0$ & $13 \cdot 1$ & 14 & $6 \cdot 7$ & $2 \cdot 1$ & $41 \cdot 3$ & 391 & $9 \cdot 5$ \\
\hline 16 & $18 \cdot 8$ & $76 \cdot 2$ & 0.011 & $0 \cdot 1$ & $-1 \cdot 3$ & $77 \cdot 6$ & - & 14 & $5 \cdot 5$ & $2 \cdot 2$ & $40 \cdot 0$ & 468 & $11 \cdot 7$ \\
\hline 30 & $19 \cdot 1$ & $82 \cdot 8$ & 0.012 & $0 \cdot 3$ & $6 \cdot 6$ & $67 \cdot 9$ & $10 \cdot 3$ & 14 & $4 \cdot 8$ & $2 \cdot 5$ & $46 \cdot 6$ & 536 & $11 \cdot 5$ \\
\hline
\end{tabular}

TABle 44. : L9.

\begin{tabular}{|c|c|c|c|c|c|c|c|c|c|c|c|c|c|}
\hline June 24 & $19 \cdot 7$ & $57 \cdot 5$ & $0 \cdot 008$ & - & - & - & - & - & 一 & - & - & - & - \\
\hline July 8 & $19 \cdot 8$ & $59 \cdot 0$ & 0.008 & $0 \cdot 1$ & 1.5 & $58 \cdot 2$ & $38 \cdot 8$ & 14 & $4 \cdot 2$ & $0 \cdot 1$ & $1 \cdot 5$ & 58 & 38.8 \\
\hline,,$\quad 22$ & $20 \cdot 0$ & $68 \cdot 9$ & 0.009 & $0 \cdot 2$ & $9 \cdot 9$ & $82 \cdot 5$ & $8 \cdot 3$ & 14 & $5 \cdot 9$ & $0 \cdot 3$ & $11 \cdot 4$ & 141 & 12.4 \\
\hline Aug. 5 & $20 \cdot 4$ & $79 \cdot 8$ & 0.009 & 0.4 & $10 \cdot 9$ & $102 \cdot 3$ & $9 \cdot 4$ & 14 & $7 \cdot 3$ & $0 \cdot 7$ & $22 \cdot 3$ & 243 & $10 \cdot 4$ \\
\hline,$\quad 19$ & $20 \cdot 9$ & $93 \cdot 6$ & 0.010 & 0.5 & $13 \cdot 8$ & $102 \cdot 7$ & $7 \cdot 4$ & 14 & $7 \cdot 3$ & $1 \cdot 2$ & $36 \cdot 1$ & 346 & $9 \cdot 6$ \\
\hline Sept. 2 & $21 \cdot 2$ & $98 \cdot 3$ & 0.010 & $0 \cdot 3$ & $4 \cdot 7$ & $110 \cdot 0$ & $23 \cdot 4$ & 14 & $7 \cdot 9$ & $1 \cdot 5$ & $40 \cdot 8$ & 456 & $11 \cdot 2$ \\
\hline,$\quad 16$ & $21 \cdot 3$ & $99 \cdot 4$ & 0.010 & $0 \cdot 1$ & $1 \cdot 1$ & $107 \cdot 1$ & $97 \cdot 4$ & 14 & $7 \cdot 0$ & $1 \cdot 6$ & $41 \cdot 9$ & 563 & $13 \cdot 4$ \\
\hline 30 & $21 \cdot 3$ & $102 \cdot 6$ & 0.011 & nil & $3 \cdot 2$ & $113 \cdot 1$ & $35 \cdot 3$ & 14 & $2 \cdot 5$ & $1 \cdot 6$ & $45 \cdot 1$ & 676 & $15 \cdot 0$ \\
\hline & & & & & & $E 4$ & $: 1$ & & & & & & \\
\hline June 24 & $18 \cdot 1$ & $44 \cdot 0$ & 0.007 & - & & - & - & - & - & - & - & - & - \\
\hline July & $18 \cdot 4$ & $50 \cdot 3$ & 0.008 & $0 \cdot 3$ & $6 \cdot 3$ & $57 \cdot 7$ & $9 \cdot 2$ & 14 & $4 \cdot 1$ & $0 \cdot 3$ & $6 \cdot 3$ & 58 & $9 \cdot 2$ \\
\hline 22 & $18 \cdot 5$ & $58 \cdot 7$ & 0.009 & $0 \cdot 1$ & $8 \cdot 4$ & $73 \cdot 0$ & $8 \cdot 7$ & 14 & $5 \cdot 2$ & 0.4 & $14 \cdot 7$ & 131 & $8 \cdot 9$ \\
\hline Aug. 5 & $18 \cdot 8$ & $62 \cdot 7$ & 0.009 & $0 \cdot 3$ & $4 \cdot 0$ & $76 \cdot 3$ & $19 \cdot 1$ & 14 & $5 \cdot 4$ & $0 \cdot 7$ & $18 \cdot 7$ & 207 & $11 \cdot 1$ \\
\hline,$\quad 19$ & $19 \cdot 3$ & $73 \cdot 3$ & 0.010 & 0.5 & $10 \cdot 6$ & $78 \cdot 6$ & $7 \cdot 4$ & 14 & $5 \cdot 6$ & $1 \cdot 2$ & $29 \cdot 3$ & 286 & $9 \cdot 8$ \\
\hline Sept. 2 & $19 \cdot 8$ & $81 \cdot 6$ & 0.011 & $0 \cdot 5$ & $8 \cdot 3$ & $82 \cdot 8$ & $10 \cdot 0$ & 14 & $5 \cdot 9$ & $1 \cdot 7$ & $37 \cdot 6$ & 368 & $9 \cdot 8$ \\
\hline$\Rightarrow \quad 16$ & $20 \cdot 1$ & $87 \cdot 1$ & 0.011 & $0 \cdot 3$ & $5 \cdot 5$ & $83 \cdot 7$ & $15 \cdot 2$ & 14 & $6 \cdot 0$ & $2 \cdot 0$ & $43 \cdot 1$ & 452 & $10 \cdot 5$ \\
\hline 30 & $20 \cdot 7$ & $102 \cdot 5$ & 0.012 & $0 \cdot 6$ & $15 \cdot 4$ & $86 \cdot 4$ & $5 \cdot 6$ & 14 & $6 \cdot 2$ & $2 \cdot 6$ & $58 \cdot 5$ & 538 & $9 \cdot 2$ \\
\hline Oet. & $21 \cdot 2$ & $109 \cdot 0$ & 0.011 & 0.5 & $6 \cdot 5$ & $87 \cdot 2$ & $13 \cdot 4$ & 14 & $6 \cdot 2$ & $3 \cdot 1$ & $\begin{array}{l}65 \cdot 0 \\
67.7\end{array}$ & 626 & $\begin{array}{r}9 \cdot 6 \\
9.3\end{array}$ \\
\hline v" & $\begin{array}{l}21 \cdot 7 \\
91.8\end{array}$ & 111.7 & 0.011 & 0.5 & $\begin{array}{l}2 \cdot 7 \\
3.0\end{array}$ & $73 \cdot 8$ & $27 \cdot 3$ & 14 & $5 \cdot 3$ & $\begin{array}{l}3 \cdot 6 \\
3.7\end{array}$ & $\begin{array}{l}67 \cdot 7 \\
70.7\end{array}$ & $\begin{array}{l}699 \\
749\end{array}$ & $\begin{array}{l}10.3 \\
10.6\end{array}$ \\
\hline v. 11 & $\begin{array}{l}21.8 \\
21.8\end{array}$ & $\begin{array}{l}114 \cdot 7 \\
11.4\end{array}$ & $\begin{array}{l}0.011 \\
0.011\end{array}$ & $\begin{array}{l}0.1 \\
\text { nil }\end{array}$ & $\begin{array}{r}3 \cdot 0 \\
-3.3\end{array}$ & $\begin{array}{r}50 \cdot 0 \\
8.4\end{array}$ & $16 \cdot 7$ & 14 & $\begin{array}{l}3 \cdot 6 \\
0 \cdot 6\end{array}$ & $\begin{array}{l}3 \cdot 7 \\
3 \cdot 7\end{array}$ & 67.4 & 758 & $\begin{array}{l}10.0 \\
11.2\end{array}$ \\
\hline Dec. 9 & $21 \cdot 9$ & $108 \cdot 7$ & 0.010 & $0 \cdot 1$ & $-2 \cdot 7$ & 1.9 & - & 14 & $0 \cdot 1$ & $3 \cdot 8$ & $64 \cdot 7$ & 760 & $11 \cdot 7$ \\
\hline,,$\quad 23$ & $22 \cdot 0$ & $104 \cdot 5$ & 0.010 & $0 \cdot 1$ & $-4 \cdot 2$ & $2 \cdot 7$ & - & 14 & $0 \cdot 2$ & $3 \cdot 9$ & $60 \cdot 5$ & 763 & $12 \cdot 6$ \\
\hline
\end{tabular}


TABLES $46-49$.

Maximum Requirements and Growth of Female Plaice.

TABLE $46:$ L15.

\begin{tabular}{|c|c|c|c|c|c|c|c|c|c|c|c|c|c|}
\hline \multirow{2}{*}{$\begin{array}{l}\text { Date. } \\
(1929)\end{array}$} & \multicolumn{2}{|c|}{$\begin{array}{l}\text { Size } \\
\text { of } \\
\text { flish. }\end{array}$} & \multirow[t]{2}{*}{ Wt./I.th. ${ }^{3}$} & \multirow{2}{*}{\multicolumn{4}{|c|}{$\begin{array}{c}\text { Gm. of } \\
\text { food } \\
\text { per } \\
1.0 \mathrm{gm} . \\
\text { increase } \\
\text { in } \\
\text { weight } \\
\text { of fish. }\end{array}$}} & \multirow[t]{2}{*}{$\begin{array}{c}\text { No. of } \\
\text { days } \\
\text { in } \\
\text { period. }\end{array}$} & \multirow{2}{*}{$\begin{array}{c}\text { Food } \\
\text { per day } \\
\text { during } \\
\text { each } \\
\text { period. } \\
\text { (gm.) }\end{array}$} & $\underset{\text { gro }}{\text { Cumt }}$ & $\begin{array}{l}\text { alative } \\
\text { wth. }\end{array}$ & \multirow{2}{*}{$\begin{array}{c}\text { Total } \\
\text { food } \\
\text { to date } \\
\text { from } \\
\text { June } 24 \\
\text { (gm.) }\end{array}$} & \multirow[t]{2}{*}{$\begin{array}{l}\text { Gm. of } \\
\text { food per } \\
1.0 \mathrm{gm} . \\
\text { increas } \\
\text { in wt. } \\
\text { of fish } \\
\text { to date }\end{array}$} \\
\hline & Lth. & Wt. & & & & & & & & Lth. & Wt. & & \\
\hline June 24 & $15 \cdot 1$ & 31.9 & 0.009 & - & & - & - & - & - & - & & - & - \\
\hline July 8 & $16 \cdot 8$ & $38 \cdot 1$ & 0.008 & $1 \cdot 7$ & $6 \cdot 2$ & $55 \cdot 7$ & $9 \cdot 0$ & 14 & $4 \cdot 0$ & $1 \cdot 7$ & $6 \cdot 2$ & 56 & $9 \cdot 0$ \\
\hline,$\quad 22$ & $17 \cdot 4$ & $49 \cdot 5$ & 0.009 & $0 \cdot 6$ & $11 \cdot 4$ & $77 \cdot 2$ & $6 \cdot 8$ & 14 & $5 \cdot 5$ & $2 \cdot 3$ & $17 \cdot 6$ & 133 & $7 \cdot 6$ \\
\hline Aug. 5 & $17 \cdot 9$ & $57 \cdot 5$ & 0.010 & 0.5 & $8 \cdot 0$ & $91 \cdot 0$ & $11 \cdot 4$ & 14 & $6 \cdot 5$ & $2 \cdot 8$ & $25 \cdot 6$ & 224 & $8 \cdot 7$ \\
\hline ,, 19 & $18 \cdot 8$ & $72 \cdot 2$ & 0.011 & 0.9 & $14 \cdot 7$ & $91 \cdot 2$ & $6 \cdot 2$ & 14 & $6 \cdot 5$ & $3 \cdot 7$ & $40 \cdot 3$ & 315 & $7 \cdot 8$ \\
\hline Sept. 2 & $19 \cdot 7$ & $85 \cdot 5$ & 0.011 & 0.9 & $13 \cdot 3$ & $97 \cdot 6$ & $7 \cdot 3$ & 14 & $7 \cdot 0$ & $4 \cdot 6$ & $53 \cdot 6$ & 413 & $7 \cdot 7$ \\
\hline,,$\quad 16$ & $20 \cdot 2$ & $91 \cdot 8$ & 0.011 & 0.5 & $6 \cdot 3$ & $95 \cdot 4$ & $15 \cdot 1$ & 14 & $6 \cdot 8$ & $5 \cdot 1$ & $59 \cdot 9$ & 507 & $8 \cdot 5$ \\
\hline 30 & $21 \cdot 1$ & $112 \cdot 5$ & 0.012 & 0.9 & $20 \cdot 7$ & $101 \cdot 1$ & $4 \cdot 9$ & 14 & $7 \cdot 2$ & $6 \cdot 0$ & $80 \cdot 6$ & 608 & $7 \cdot 5$ \\
\hline Oet. 14 & $22 \cdot 1$ & 123.8 & 0.011 & $1 \cdot 0$ & $11 \cdot 3$ & $101 \cdot 3$ & $9 \cdot 0$ & 14 & $7 \cdot 2$ & $7 \cdot 0$ & $91 \cdot 9$ & 709 & $7 \cdot 7$ \\
\hline,,$\quad 28$ & $22 \cdot 7$ & $137 \cdot 6$ & 0.012 & $0 \cdot 6$ & $13 \cdot 8$ & $83 \cdot 2$ & $6 \cdot 0$ & 14 & $5 \cdot 9$ & $7 \cdot 6$ & $105 \cdot 7$ & 792 & $7 \cdot 5$ \\
\hline Nov. 11 & $23 \cdot 0$ & $141 \cdot 1$ & 0.012 & $0 \cdot 3$ & $3 \cdot 5$ & $65 \cdot 4$ & $18 \cdot 4$ & 14 & $4 \cdot 7$ & $7 \cdot 9$ & $109 \cdot 2$ & 858 & $7 \cdot 9$ \\
\hline,,$\quad 25$ & $23 \cdot 0$ & $140 \cdot 7$ & 0.012 & nil & -0.4 & $24 \cdot 8$ & - & 14 & 1.8 & $7 \cdot 9$ & $108 \cdot 8$ & 883 & $8 \cdot 1$ \\
\hline Dec. 9 & $23 \cdot 0$ & $137 \cdot 0$ & $0 \cdot 011$ & nil & $-3 \cdot 7$ & $4 \cdot 6$ & - & 14 & $0 \cdot 3$ & $7 \cdot 9$ & $105 \cdot 1$ & 888 & $8 \cdot 4$ \\
\hline ,, 23 & $23 \cdot 0$ & $135 \cdot 5$ & 0.011 & nil & $-1 \cdot 5$ & $8 \cdot 0$ & - & 14 & $0 \cdot 6$ & $7 \cdot 9$ & $103 \cdot 6$ & 896 & $8 \cdot 6$ \\
\hline & & & & & & E 47 . & . : L1 & & & & & & \\
\hline June 24 & $18 \cdot 4$ & $50 \cdot 5$ & 0.008 & - & - & - & - & - & - & - & & - & - \\
\hline July 8 & $18 \cdot 8$ & $61 \cdot 1$ & 0.009 & $0 \cdot 4$ & $10 \cdot 6$ & $61 \cdot 2$ & $5 \cdot 8$ & 14 & $4 \cdot 4$ & 0.4 & $10 \cdot 6$ & 61 & $5 \cdot 8$ \\
\hline,$\quad 22$ & $19 \cdot 1$ & $70 \cdot 5$ & 0.010 & $0 \cdot 3$ & $9 \cdot 4$ & $81 \cdot 5$ & $8 \cdot 6$ & 14 & $5 \cdot 8$ & $0 \cdot 7$ & $20 \cdot 0$ & 143 & $7 \cdot 1$ \\
\hline Aug. 5 & $19 \cdot 6$ & $83 \cdot 4$ & $0 \cdot 011$ & 0.5 & $12 \cdot 9$ & $102 \cdot 2$ & $7 \cdot 9$ & 14 & $7 \cdot 3$ & $1 \cdot 2$ & $32 \cdot 9$ & 245 & $7 \cdot 4$ \\
\hline,$\quad 19$ & $20 \cdot 5$ & $99 \cdot 9$ & 0.012 & 0.9 & $16 \cdot 5$ & $109 \cdot 5$ & $6 \cdot 6$ & 14 & $7 \cdot 8$ & $2 \cdot 1$ & $49 \cdot 4$ & 354 & $7 \cdot 2$ \\
\hline Sept. 2 & $21 \cdot 3$ & $117 \cdot 5$ & 0.012 & $0 \cdot 8$ & $17 \cdot 6$ & $118 \cdot 5$ & $6 \cdot 7$ & 14 & $8 \cdot 5$ & $2 \cdot 9$ & $67 \cdot 0$ & 473 & $7 \cdot 1$ \\
\hline,$\quad 16$ & $21 \cdot 7$ & $130 \cdot 5$ & 0.013 & $0 \cdot 4$ & $13 \cdot 0$ & $122 \cdot 3$ & $9 \cdot 4$ & 14 & $8 \cdot 7$ & $3 \cdot 3$ & $80 \cdot 0$ & 595 & $7 \cdot 4$ \\
\hline ,, 30 & $22 \cdot 5$ & $147 \cdot 1$ & 0.013 & $0 \cdot 8$ & $16 \cdot 6$ & $124 \cdot 0$ & $7 \cdot 5$ & 14 & $8 \cdot 9$ & $4 \cdot 1$ & $96 \cdot 6$ & 719 & $7 \cdot 4$ \\
\hline Oct. 14 & $23 \cdot 0$ & $169 \cdot 1$ & $0 \cdot 014$ & 0.5 & $22 \cdot 0$ & $124 \cdot 7$ & $5 \cdot 7$ & 14 & $8 \cdot 9$ & $4 \cdot 6$ & $118 \cdot 6$ & 844 & $7 \cdot 1$ \\
\hline , 28 & $23 \cdot 7$ & $179 \cdot 6$ & 0.014 & $0 \cdot 7$ & $10 \cdot 5$ & $107 \cdot 6$ & $10 \cdot 2$ & 14 & $7 \cdot 7$ & $5 \cdot 3$ & $129 \cdot 1$ & 951 & $7 \cdot 4$ \\
\hline Nov. 11 & $24 \cdot 0$ & $179 \cdot 3$ & 0.013 & $0 \cdot 3$ & -0.3 & $81 \cdot 9$ & - & 14 & $5 \cdot 8$ & $5 \cdot 6$ & $128 \cdot 8$ & 1033 & $8 \cdot 0$ \\
\hline ", 25 & $24 \cdot 1$ & $175 \cdot 0$ & 0.012 & 0.1 & $-4 \cdot 3$ & $26 \cdot 6$ & - & 14 & 1.9 & $5 \cdot 7$ & $124 \cdot 5$ & 1060 & $8 \cdot 5$ \\
\hline Dec. 9 & $24 \cdot 1$ & $171 \cdot 1$ & 0.012 & nil & $-3 \cdot 9$ & $6 \cdot 4$ & - & 14 & 0.5 & $5 \cdot 7$ & $120 \cdot 6$ & 1066 & $8 \cdot 8$ \\
\hline , 23 & $24 \cdot 1$ & $170 \cdot 8$ & 0.012 & nil & -0.3 & $10 \cdot 6$ & - & 14 & 0.8 & $5 \cdot 7$ & $120 \cdot 3$ & 1077 & $8 \cdot 9$ \\
\hline
\end{tabular}

TABle 48: L13.

\begin{tabular}{|c|c|c|c|c|c|c|c|c|c|c|c|c|c|}
\hline June 24 & $15 \cdot 1$ & $27 \cdot 0$ & 0.008 & \multicolumn{2}{|c|}{ - } & - & - & - & - & \multicolumn{2}{|c|}{ - } & - & - \\
\hline July 8 & $15 \cdot 5$ & $31 \cdot 1$ & 0.008 & 0.4 & $4 \cdot 1$ & $36 \cdot 7$ & $9 \cdot 0$ & 14 & $2 \cdot 6$ & 0.4 & $4 \cdot 1$ & 37 & 9.0 \\
\hline,$\quad 22$ & $15 \cdot 9$ & $40 \cdot 6$ & 0.010 & $0 \cdot 4$ & $9 \cdot 5$ & $70 \cdot 0$ & $7 \cdot 4$ & 14 & $5 \cdot 0$ & 0.8 & $13 \cdot 6$ & 107 & $7 \cdot 9$ \\
\hline Aug. 5 & $16 \cdot 6$ & $48 \cdot 1$ & 0.011 & 0.7 & $7 \cdot 5$ & $81 \cdot 4$ & $10 \cdot 9$ & 14 & $5 \cdot 8$ & 1.5 & $21 \cdot 1$ & 188 & 8.9 \\
\hline ,, 19 & $17 \cdot 3$ & $55 \cdot 6$ & 0.011 & 0.7 & $7 \cdot 5$ & $68 \cdot 8$ & $9 \cdot 2$ & 14 & 4.9 & $2 \cdot 2$ & $28 \cdot 6$ & 257 & $9 \cdot 0$ \\
\hline Sept. 2 & $17 \cdot 8$ & $61 \cdot 9$ & 0.011 & 0.5 & $6 \cdot 3$ & $67 \cdot 6$ & $10 \cdot 7$ & 14 & $4 \cdot 8$ & $2 \cdot 7$ & $34 \cdot 9$ & 324 & $9 \cdot 3$ \\
\hline,,$\quad 16$ & $18 \cdot 5$ & $64 \cdot 0$ & 0.010 & 0.7 & $2 \cdot 1$ & $69 \cdot 9$ & $33 \cdot 3$ & 14 & $5 \cdot 0$ & $3 \cdot 4$ & $37 \cdot 0$ & 394 & $10 \cdot 6$ \\
\hline 30 & $18 \cdot 7$ & $69 \cdot 0$ & 0.011 & 0.2 & $5 \cdot 0$ & $70 \cdot 3$ & $14 \cdot 1$ & 14 & $5 \cdot 0$ & $3 \cdot 6$ & $42 \cdot 0$ & 464 & $11 \cdot 0$ \\
\hline Oct. 14 & $19 \cdot 0$ & $71 \cdot 8$ & 0.010 & $0 . \overline{3}$ & $2 \cdot 8$ & $70 \cdot 0$ & $25 \cdot 0$ & 14 & $5 \cdot 0$ & $3 \cdot 9$ & $44 \cdot 8$ & 534 & 11.9 \\
\hline , 28 & $19 \cdot 2$ & $71 \cdot 4$ & 0.010 & 0.2 & -0.4 & $48 \cdot 4$ & - & 14 & $3 \cdot 5$ & $4 \cdot 1$ & $44 \cdot 4$ & 583 & $13 \cdot 1$ \\
\hline Nov. 11 & $19 \cdot 2$ & $71 \cdot 0$ & 0.010 & nil & $-0 \cdot 4$ & $36 \cdot 3$ & 一 & 14 & $2 \cdot 6$ & $4 \cdot 1$ & $44 \cdot 0$ & 619 & $14 \cdot 1$ \\
\hline,, 25 & $19 \cdot 2$ & $70 \cdot 4$ & 0.010 & nil & -0.6 & $7 \cdot 2$ & - & 14 & 0.5 & $4 \cdot 1$ & $43 \cdot 4$ & 626 & $14 \cdot 4$ \\
\hline Dec. 9 & $19 \cdot 2$ & $69 \cdot 1$ & 0.010 & nil & $-1 \cdot 3$ & $3 \cdot 7$ & - & 14 & $0 \cdot 3$ & $4 \cdot 1$ & $42 \cdot 1$ & 630 & $15 \cdot 0$ \\
\hline ,. 23 & $19 \cdot 2$ & $68 \cdot 5$ & 0.010 & nil & $-0 \cdot 6$ & $5 \cdot 1$ & - & 14 & $0 \cdot 4$ & $4 \cdot 1$ & $41 \cdot 5$ & 635 & $15 \cdot 3$ \\
\hline
\end{tabular}


TABle 49: L14.

\begin{tabular}{|c|c|c|c|c|c|c|c|c|c|c|c|c|c|}
\hline \multirow[b]{2}{*}{$\begin{array}{l}\text { Date. } \\
(1929)\end{array}$} & \multirow{2}{*}{\multicolumn{3}{|c|}{ Wt. $/$ Lth. $^{3}$}} & & $\begin{array}{l}\text { wth } \\
\text { er } \\
\text { riod. }\end{array}$ & \multirow{2}{*}{\multicolumn{2}{|c|}{$\begin{array}{cc}\text { Gm. of } \\
\text { food } \\
\text { per } \\
1.0 \mathrm{gm} . \\
\text { al } \\
\text { d increase } \\
\text { in } \\
\text { weight } \\
\text { d. of fish. }\end{array}$}} & \multirow[t]{2}{*}{$\begin{array}{c}\text { No. of } \\
\text { days } \\
\text { in } \\
\text { Deriod. }\end{array}$} & \multirow{2}{*}{$\begin{array}{c}\text { Food } \\
\text { per day } \\
\text { during } \\
\text { each } \\
\text { period. } \\
\text { (gm.) }\end{array}$} & $\underset{\mathrm{gr}}{\mathrm{Cum}}$ & $\begin{array}{l}\text { ulative } \\
\text { owth. }\end{array}$ & \multirow[t]{2}{*}{$\begin{array}{l}\text { Total } \\
\text { food } \\
\text { to date } \\
\text { from } \\
\text { June } 24 \\
\text { (gm.) }\end{array}$} & \multirow[t]{2}{*}{$\begin{array}{l}\text { Gm. of } \\
\text { food per } \\
1.0 \mathrm{gm} \text {. } \\
\text { increase } \\
\text { in wt. } \\
\text { of fish } \\
\text { to date. }\end{array}$} \\
\hline & & & & Lth. & wt. & & & & & Lth. & Wt. & & \\
\hline July 15 & $3 \cdot 0$ & $90 \cdot 1$ & 0.007 & & & - & 一 & 一 & - & & - & - & - \\
\hline,$\quad 22$ & $23 \cdot 0$ & $87 \cdot 6$ & 0.007 & nil & $-2 \cdot 5$ & $31 \cdot 7$ & - & 7 & $4 \cdot 5$ & nil & $-2 \cdot 5$ & 32 & - \\
\hline ug. 5 & $23 \cdot 1$ & $97 \cdot 3$ & 0.008 & $0 \cdot 1$ & $9 \cdot 7$ & $96 \cdot 7$ & $10 \cdot 0$ & 14 & $6 \cdot 9$ & $0 \cdot 1$ & $7 \cdot 2$ & 128 & $17 \cdot 8$ \\
\hline,$\quad 19$ & $23 \cdot 4$ & $112 \cdot 5$ & 0.009 & $0 \cdot 3$ & $15 \cdot 2$ & $105 \cdot 9$ & $7 \cdot 0$ & 14 & $7 \cdot 6$ & 0.4 & $22 \cdot 4$ & 234 & $10 \cdot 4$ \\
\hline sept. 2 & $23 \cdot 6$ & $122 \cdot 6$ & 0.009 & 0.2 & $10 \cdot 1$ & $110 \cdot 7$ & $11 \cdot 0$ & 14 & $7 \cdot 4$ & $0 \cdot 6$ & $32 \cdot 5$ & 345 & $10 \cdot 6$ \\
\hline,$\quad 16$ & $23 \cdot 8$ & $135 \cdot 7$ & 0.010 & $0 \cdot 2$ & $13 \cdot 1^{\circ}$ & $113 \cdot 3$ & $8 \cdot 6$ & 14 & 8 . & $0 \cdot 8$ & $45 \cdot 6$ & 458 & $10 \cdot 0$ \\
\hline , 30 & $24 \cdot 3$ & 151.2 & .0 & 0.5 & $15 \cdot 5$ & $115 \cdot 2$ & $7 \cdot 4$ & 14 & 8 & $1 \cdot 3$ & $61 \cdot 1$ & 573 & $9 \cdot 4$ \\
\hline Oct. 14 & $24 \cdot 7$ & $165 \cdot 7$ & 0.011 & 0.4 & $14 \cdot 5$ & $114 \cdot 4$ & $7 \cdot 9$ & 14 & $8 \cdot 2$ & $1 \cdot 7$ & $75 \cdot 6$ & 687 & $9 \cdot 1$ \\
\hline,$\quad 28$ & $25 \cdot 3$ & $174 \cdot 5$ & 0.011 & $0 \cdot 6$ & $8 \cdot 8$ & $94 \cdot 3$ & $10 \cdot 7$ & 14 & $6 \cdot 7$ & $2 \cdot 3$ & $84 \cdot 4$ & 782 & $9 \cdot 3$ \\
\hline Nov. 11 & $25 \cdot 6$ & $186 \cdot 5$ & 0.011 & $0 \cdot 3$ & $12 \cdot 0$ & $85 \cdot 5$ & $7 \cdot 1$ & & $6 \cdot 1$ & $2 \cdot 6$ & $96 \cdot 4$ & 867 & $9 \cdot($ \\
\hline 25 & $25 \cdot 7$ & $184 \cdot 8$ & & $0 \cdot 1$ & $-1 \cdot 7$ & $37 \cdot 7$ & - & 14 & $2 \cdot 7$ & $2 \cdot 7$ & $94 \cdot 7$ & 905 & $9 \cdot 6$ \\
\hline ec. 9 & $5 \cdot 7$ & $179 \cdot 2$ & 0.01 & nil & $-5 \cdot 6$ & $7 \cdot 8$ & - & 14 & $0 \cdot 6$ & $2 \cdot 7$ & $89 \cdot 1$ & 913 & $10 \cdot 3$ \\
\hline , 23 & $25 \cdot 7$ & $179 \cdot 1$ & 0.011 & nil & $-0 \cdot 1$ & $12 \cdot 5$ & - & 14 & 0.9 & $2 \cdot 7$ & $89 \cdot 0$ & 926 & $10 \cdot 4$ \\
\hline
\end{tabular}

TABLE 50.

Showing Percentage Growth in Weight of Specified Male and Female Plaice for each Period at Cawsand and Lympstone.

[A] Cawsand.

$\begin{array}{lccc}\text { Date } & \text { B1 } & \text { B4 } & \text { D3 } \\ {[1929]} & \wp & \uparrow & \text { o }\end{array}$

Miay 22

June 6 20

July 5

19

Aug. 2

16
30

$29 \cdot 2$

$$
12 \cdot 9
$$

$14 \cdot 3$

$$
40 \cdot 5
$$

$$
23 \cdot 1
$$

$14 \cdot 1$

$16 \cdot 1$

$25 \cdot 0$

$33 \cdot 3$

$13 \cdot 8 \quad 17 \cdot 4$

$23 \cdot 3$

$12 \cdot 2$

Sept. 16

$14 \cdot 0$

$19 \cdot 8$

$24 \cdot 1$

Oct. 1

$13 \cdot 1$

$9 \cdot 1$

$27 \cdot 2$

$15 \cdot 2$

$20 \cdot 6$

$13 \cdot 9$

15

$7 \cdot 3$

$7 \cdot 8$

$2 \cdot 6$

$13 \cdot 3$

$6 \cdot 1$

Nov. $13 \quad 5 \cdot 6 \quad 5 \cdot 9 \quad 7 \cdot 9$
$1 \cdot 4$
1.9
[B] Lympstone.

$\begin{array}{cccc}\text { Date } & \text { L15 } & \text { L16 } & \text { L11 } \\ {[1929]} & + & + & \delta\end{array}$

$\begin{array}{lrrrr}\text { June } 24 & - & - & - \\ \text { July } & 8 & 19 \cdot 4 & 21 \cdot 0 & - \\ & 22 & 30 \cdot 0 & 15 \cdot 4 & 26 \cdot 2 \\ \text { Aug. } & 5 & 16 \cdot 2 & 18 \cdot 3 & 9 \cdot 0 \\ & 19 & 25 \cdot 6 & 19 \cdot 8 & 246 \\ \text { Sept. } 2 & 18 \cdot 4 & 17 \cdot 6 & 16 \cdot 8 \\ & 16 & 7 \cdot 4 & 11 \cdot 1 & 9 \cdot 2 \\ & 30 & 22 \cdot 5 & 12 \cdot 7 & 15 \cdot 8 \\ \text { Oct. } & 14 & 10 \cdot 0 & 15 \cdot 0 & 12 \cdot 4 \\ & 28 & 11 \cdot 1 & 6 \cdot 2 & 8 \cdot 1\end{array}$


TABLE 51.

Maintenance of Male Plaice at Cawsand (1928 and 1929) and at Lympstone (1929). Summarised Data.

\begin{tabular}{|c|c|c|c|c|c|c|c|}
\hline Exp. & $\begin{array}{l}\text { Fish } \\
\text { No. }\end{array}$ & 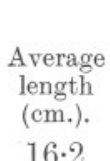 & $\begin{array}{c}\text { Average } \\
\text { weight } \\
\text { (gm.). } \\
49.3\end{array}$ & $\begin{array}{l}\text { Average } \\
\text { daily } \\
\text { ration } \\
\text { (gm.). } \\
0.7\end{array}$ & $\begin{array}{c}\text { Food per } \\
\text { day/ } \\
\text { /average } \\
\text { body-wt. } \\
0.017\end{array}$ & $\begin{array}{c}\text { Tables } \\
\text { for } \\
\text { refer- } \\
\text { ence. } \\
1\end{array}$ & $\begin{array}{l}\text { Period } \\
\text { to date } \\
\text { given } \\
\text { below. } \\
\text { Nov. } 30\end{array}$ \\
\hline & & $16 \cdot 2$ & $42 \cdot 3$ & $0 \cdot 7$ & & & \\
\hline C. 1929 & Mean C & $12 \cdot 8$ & $17 \cdot 6$ & $0 \cdot 4$ & $0 \cdot 024$ & 8 & July 5 \\
\hline , & C5a & $14 \cdot 6$ & $30 \cdot 0$ & $0 \cdot 6$ & $0 \cdot 019$ & $9 \& 12$ & Nov. 28 \\
\hline , & $\mathrm{C} 4 \mathrm{a}$ & $15 \cdot 9$ & $39 \cdot 0$ & $0 \cdot 6$ & $0 \cdot 015$ & $10 \& 12$ & Nov. 13 \\
\hline ," & $\mathrm{C} 6 \mathrm{a}$ & $16 \cdot 7$ & $43 \cdot 0$ & $0 \cdot 7$ & $0 \cdot 016$ & $11 \& 12$ & Nov. 28 \\
\hline L. 1929 & L1 & $17 \cdot 3$ & $52 \cdot 2$ & $0 \cdot 9$ & $0 \cdot 017$ & $28 \& 33$ & Nov. 25 \\
\hline, & $\mathrm{L} 4 \mathrm{~b}$ & $20 \cdot 9$ & $76 \cdot 0$ & $1 \cdot 1$ & $0 \cdot 015$ & $29 \& 33$ & ", \\
\hline , & L3 & $21 \cdot 7$ & $107 \cdot 3$ & $1 \cdot 3$ & $0 \cdot 012$ & $30 \& 33$ & , \\
\hline , & L2 & $22 \cdot 9$ & $129 \cdot 7$ & $1 \cdot 4$ & $0 \cdot 011$ & $31 \& 33$ & , \\
\hline
\end{tabular}

TABLE 52.

Matntenance of Female Plaice at Cawsand (1928 and 1929) and at Lympstone (1929). Summarised Data.

\begin{tabular}{|c|c|c|c|c|c|c|c|}
\hline Exp. & $\begin{array}{l}\text { Fish } \\
\text { No. }\end{array}$ & $\begin{array}{l}\text { Average } \\
\text { length } \\
(\mathrm{cm} .) .\end{array}$ & $\begin{array}{c}\text { Average } \\
\text { weight } \\
\text { (gm.). }\end{array}$ & $\begin{array}{c}\text { Average } \\
\text { Daily } \\
\text { ration } \\
\text { (gm.). }\end{array}$ & $\begin{array}{l}\text { Food per } \\
\text { day/ } \\
\text { /average } \\
\text { body·wt. }\end{array}$ & $\begin{array}{l}\text { Tables } \\
\text { for } \\
\text { refer- } \\
\text { ence. }\end{array}$ & $\begin{array}{c}\text { Period } \\
\text { to date } \\
\text { given } \\
\text { below. }\end{array}$ \\
\hline C. 1928 & Mean B & $14 \cdot 2$ & $29 \cdot 6$ & $0 \cdot 6$ & $0 \cdot 021$ & 2 & Nov. 30 \\
\hline ", & $\begin{array}{c}\text { Suggested } \\
\text { mean B }\end{array}$ & - & 25 & $\begin{array}{c}0.4 \text { to } \\
0.5\end{array}$ & $\begin{array}{l}0 \cdot 016 \text { to } \\
0 \cdot 020\end{array}$ & - & - \\
\hline C. 1929 & Mean A & $13 \cdot 7$ & $22 \cdot 3$ & $0 \cdot 4$ & $0 \cdot 019$ & 8 & July 5 \\
\hline, & $\mathrm{A} 4 \mathrm{a}$ & $16 \cdot 3$ & $40 \cdot 5$ & $0 \cdot 6$ & $0 \cdot 016$ & $13 \& 16$ & Nov. 27 \\
\hline , & A6a & $16 \cdot 3$ & $42 \cdot 0$ & $0 \cdot 6$ & $0 \cdot 015$ & $14 \& 16$ & ", \\
\hline , & $\mathrm{A} 3 \mathrm{a}$ & $17 \cdot 7$ & $56 \cdot 5$ & $0 \cdot 8$ & $0 \cdot 015$ & $15 \& 16$ & , \\
\hline L. 1929 & L5 & $18 \cdot 5$ & $64 \cdot 8$ & 0.9 & $0 \cdot 014$ & $34 \& 38$ & Nov. 25 \\
\hline " & L6 & $19 \cdot 2$ & $70 \cdot 6$ & $1 \cdot 2$ & $0 \cdot 017$ & $35 \& 38$ & ", \\
\hline ", & L7 & $22 \cdot 5$ & $102 \cdot 7$ & $1 \cdot 3$ & $0 \cdot 013$ & $36 \& 38$ & 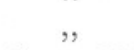 \\
\hline , & L8a & $22 \cdot 0$ & $103 \cdot 2$ & $1 \cdot 3$ & $0 \cdot 013$ & $37 \& 38$ & Sept. 30 \\
\hline & $\mathrm{L} 8 \mathrm{~b}$ & $23 \cdot 1$ & $113 \cdot 8$ & $1 \cdot 4$ & $0 \cdot 013$ & $37 \& 38$ & Nov. 25 \\
\hline
\end{tabular}


TABLE 53.

Maximum Requirements and Growth of Cawsand and Lympstone Male Plaice.

\begin{tabular}{|c|c|c|c|c|c|c|c|c|c|c|c|}
\hline \multirow{3}{*}{$\begin{array}{c}\text { Exp. } \\
\text { C. } 1928\end{array}$} & \multirow{2}{*}{$\begin{array}{l}\text { Fish } \\
\text { No. } \\
\text { Mean }\end{array}$} & \multicolumn{2}{|c|}{$\begin{array}{l}\text { Initial } \\
\text { size. }\end{array}$} & \multicolumn{2}{|c|}{$\begin{array}{l}\text { Final } \\
\text { size. }\end{array}$} & \multicolumn{2}{|c|}{ Growth. } & \multirow[t]{2}{*}{$\begin{array}{l}\text { Total } \\
\text { No. of } \\
\text { days. }\end{array}$} & \multirow{2}{*}{$\begin{array}{l}\text { Total } \\
\text { food } \\
\text { taken. } \\
\text { (gm.) }\end{array}$} & \multirow{2}{*}{$\begin{array}{c}\text { Average } \\
\text { weight } \\
\text { of food } \\
\text { Der day. } \\
\text { (gm.) }\end{array}$} & \multirow{2}{*}{$\begin{array}{c}\text { Food pe } \\
1.0 \mathrm{gm} . \\
\text { increase } \\
\text { in weight } \\
\text { of fish. } \\
\text { (gm.) }\end{array}$} \\
\hline & & Lth. & Wt. & & wt. & Lth. & Wt. & & & & \\
\hline & C & $16 \cdot 0$ & $38 \cdot 8$ & $22 \cdot 6$ & $123 \cdot 3$ & $6 \cdot 6$ & $84 \cdot 5$ & 176 & 1129 & $6 \cdot 4$ & $13 \cdot 3$ \\
\hline C. 1929 & D3 & $12 \cdot 0$ & 15.5 & $21 \cdot 0$ & 105.0 & $9 \cdot 0$ & 89.5 & 175 & 585 & $3 \cdot 3$ & $6 \cdot 5$ \\
\hline , & D2 & $12 \cdot 2$ & $15 \cdot 0$ & $17 \cdot 9$ & $64 \cdot 0$ & $5 \cdot 7$ & $49 \cdot 0$ & 175 & 471 & $2 \cdot 7$ & $9 \cdot 6$ \\
\hline , & D4 & $12 \cdot 0$ & $13 \cdot 0$ & $17 \cdot 3$ & $56 \cdot 5$ & $5 \cdot 3$ & $43 \cdot 5$ & 175 & 475 & $2 \cdot 7$ & $11 \cdot 7$ \\
\hline , & D1 & $12 \cdot 2$ & $14 \cdot 0$ & $15 \cdot 9$ & $40 \cdot 5$ & $3 \cdot 7$ & $26 \cdot 5$ & 160 & 420 & $2 \cdot 6$ & $15 \cdot 8$ \\
\hline$"$ & D5 & $11 \cdot 9$ & $14 \cdot 5$ & $15 \cdot 8$ & $38 \cdot 0$ & $3 \cdot 9$ & $23 \cdot 5$ & 190 & 424 & $2 \cdot 2$ & $18 \cdot 0$ \\
\hline L. 1929 & L11 & $16 \cdot 1$ & $23 \cdot 2$ & $23 \cdot 1$ & $157 \cdot 4$ & $7 \cdot 0$ & $134 \cdot 2$ & 154 & 953 & $6 \cdot 2$ & $7 \cdot 1$ \\
\hline , & $\mathrm{L} 12$ & 18.1 & $44 \cdot 0$ & 21.8 & $111 \cdot 4$ & $3 \cdot 7$ & $67 \cdot 4$ & 154 & 758 & 4.9 & $11 \cdot 2$ \\
\hline 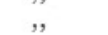 & Ll0 & $16 \cdot 6$ & $36 \cdot 2$ & $19 \cdot 1$ & $82 \cdot 8$ & 2.5 & $46 \cdot 6$ & 98 & 536 & 5.5 & $11 \cdot 5$ \\
\hline, & L9 & $19 \cdot 7$ & $57 \cdot 5$ & $21 \cdot 3$ & $102 \cdot 6$ & $1 \cdot 6$ & $45 \cdot 1$ & 98 & 676 & $6 \cdot 9$ & 15.0 \\
\hline
\end{tabular}

TABLE 54.

Maximum Requirements and Growth of Cawsand and

Lympstone Female Platce.

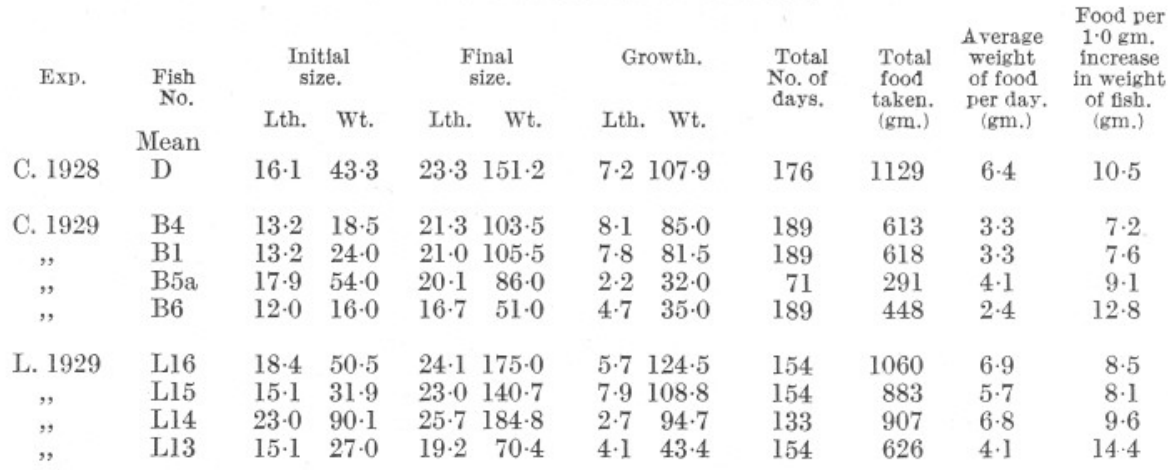

